\title{
MASTER
}

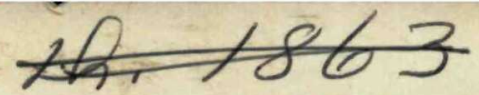

ORNL-5384

\section{Product Form Characterization of Reference Heat of Type 316 Stainless Steel}

\author{
V. K. Sikka
}

\section{Nelied techinomacy}

Any urther distribution by am of the dota therein third parties reprebuting foreign intosts, foreign governments, reign companies and veign subsidiaries foreign divisions of U.S. O panies should be co dinated with the Dhyor, Division of Reactor Research and Development, Department of Energy

\section{OAK RIDGE NATIONAL LABORATORY} OPERATED BY UNION CARBIDE CORPORATION · FOR THE DEPARTMENT OF ENERGY 


\title{
Printed in the United States of America. Available from the Department of Energy, Technical Information Center \\ P.O. Box 62, Oak Ridge, Tennessee 37830 \\ Price: Printed Copy $\$ 6.50$; Microfiche $\$ 3.00$
}

\begin{abstract}
This report was prepared as an account of work sponsored by an agency of the United States Government. Neither the United States Government nor any agency thereof, nor any of their employees, contractors, subcontractors, or their employees, makes any warranty, express or implied, nor assumes any legal liability or responsibility for any third party's use or the results of such use of any information, apparatus, product or process disclosed in this report, nor represents that its use by such third party would not infringe privately owned rights.
\end{abstract}




\section{DISCLAIMER}

This report was prepared as an account of work sponsored by an agency of the United States Government. Neither the United States Government nor any agency Thereof, nor any of their employees, makes any warranty, express or implied, or assumes any legal liability or responsibility for the accuracy, completeness, or usefulness of any information, apparatus, product, or process disclosed, or represents that its use would not infringe privately owned rights. Reference herein to any specific commercial product, process, or service by trade name, trademark, manufacturer, or otherwise does not necessarily constitute or imply its endorsement, recommendation, or favoring by the United States Government or any agency thereof. The views and opinions of authors expressed herein do not necessarily state or reflect those of the United States Government or any agency thereof. 


\section{DISCLAIMER}

Portions of this document may be illegible in electronic image products. Images are produced from the best available original document. 
ORNL -5384

Distribution

Category UC-79b, $-\mathrm{h},-\mathrm{k}$

Contract No. W-7405-eng-26

METALS AND CERAMICS DIVISION

PRODUCT FORM CHARACTERIZATION OF REFERENCE HEAT OF TYPE 316 STAINLESS STEEL

V. K. Sikka

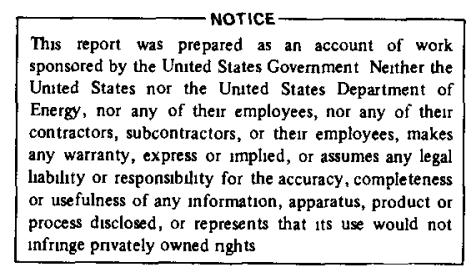

This document is
PUBLICLY RELEASABLE
David Hamrin, ORNL
Authorizing Official
Date $8-23-2011$

Date Published: February 1978

OAK RIDGE NATIONAL LABORATORY

Oak Ridge, Tennessee 37830

operated by

UNION CARBIDE CORPORATION

for the

DEPARTMENT OF ENERGY

Relesod For Annonncentin Energy

Pecserch Absmats. Distributionminited

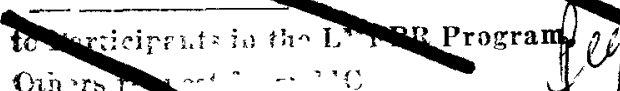

oin orston ... 
-

○ 
CONTENTS

ABSTRACT . . . . . . . . . . . . . . . . . . . 1

INTRODUCTTON . . . . . . . . . . . . . . . . . . 1

MATERIALS AND EXPERIMENTAL DETAILS . . . . . . . . . . . 2

Melting Details . . . . . . . . . . . . . . . . 2

Fabrication Processes ................ 4

Chemical Analysis . . . . . . . . . . . . 6

Microstructure . . . . . . . . . . . . . 6

Microhardness Studies . . . . . . . . . . . . . 6

Tensile Test Specimen . . . . . . . . . . . . . . 19

Tensile Test Procedure . . . . . . . . . . . . . 24

Tensile Test Matrix . . . . . . . . . . . . . 25

RESULTS AND DISCUSSION . . . . . . . . . . . . . . 25

Tensile Properties of As-Received Product Forms . . . . . . 25

Tensile Properties of Reannealed Product Forms . . . . . . 35

Estimate of Residual Cold Work in Various Product Forms from Tensile Properties in As-Received and Reannealed Material - 42

Modeling of Tensile Data for Various Product Forms . . . . 47

Effect of the Amount of Cold Work on the Room-Temperature

Tensile Properties after Subsequent Annealing . . . . . . 53

Use of the Properties of Cold-Worked-and-Annealed Specimens to Explain Variations in Tensile Properties of Various Product Forms . . . . . . . . . . . . 72

Comparison of Expected and Minimum Properties . . . . . . 73

Stress-Strain Behavior (Up to $4 \%$ Strain) . . . . . . . . 75

Relation Between Room-Temperature Yield Strength and Hardness Values . . . . . . . . . . . . . . . 79

Comparison of $0.2 \%$ Yield Strength Data with Data on Previously studied Heats . . . . . . . . . . . 80

Comparison of $0.2 \%$ Yield and Ultimate Tensile Strengths with Vendor-Certified Mechanical Property Data....... . 81

SUMMARY AND CONCLUSTONS . . . . . . . . . . . . . 85

ACKNOWLEDGMENTS . . . . . . . . . . . . . . . 88

REFERENCES .......................... . . 88

APPENDIX A - HEAT TREATMENT BACKUP WORK . . . . . . . . . 93

APPENDIX B - STRAIN RATE PACER RESULTS . . . . . . . . . 105 


\title{
PRODUCT FORM CHARACTERIZATION OF REFERENCE HEAT OF TYPE 316 STAINLESS STEEL*
}

V. K. Sikka

\begin{abstract}
The product form characterization of the reference heat (8092297) of type 316 stainless steel was completed. Ten product forms were studied: three plates, four pipes, and three bars. Melting, fabrication processes, composition variations, optical microstructure and grain size, roomtemperature Rockwell and microhardness data, and tensile properties in both mill-annealed and reannealed conditions are described. Residual cold work in various product forms was estimated from the tensile properties. Tensile data was modeled and compared with "minimum" value curves. Stress-strain curves (up to $4 \%$ ) were predicted and compared with the experimental data. Room-temperature tensile properties on various product forms were compared with the vendor certified data.

Tensile properties and microstructure of specimens cold-worked from 0 to $30 \%$ and annealed for $0.5 \mathrm{hr}$ at 1065 or $1150^{\circ} \mathrm{C}$ were studied to explain differences observed in tensile properties of various product forms.
\end{abstract}

\section{INTRODUCTION}

Austenitic stainless steels of types 304 and 316 are important structural materials for nuclear reactors and other energy systems. Mechanical properties testing programs on these materials are under way at Oak Ridge National Laboratory (ORNL). The programs include studies on:

1. product form characterization ${ }^{1-5}$ of a single heat (reference heat) of types 304 and 316 stainless stee1,

2. heat-to-heat variations ${ }^{6-8}$ in tensile and creep properties of 20 heats of type 304 and nine heats of type 316 stainless steel,

*Work performed under ERDA/RDD 189a OH050, Mechanical Properties for Structural Materials. 
3. influence 9,10 of residual stresses in mill-annealed material on tensile and creep properties of types 304 and 316 stainless stee1,

4. influence of long-term thermal aging ${ }^{11,12}$ with and without stress on tensile and creep properties of types 304 and 316 stainless steel. Work is continuing in the areas listed above, and the objective of this report is to present the product form characterization of the reference heat (8092297) of type 316 stainless steel. Specifically, this report will present the following:

1. melting details,

2. fabrication processes for different products,

3. composition variations among various product forms,

4. optical microstructure and grain size of various products,

5. room-temperature Rockwe11 and microhardness data,

6. tensile properties of various products in the mill-annealed and reannealed conditions,

7. estimate of residual cold work in various product forms from tensile properties in as-received and reannealed conditions,

8. modeling of tensile data for various product forms,

9. effect of cold work on reannealed properties,

10. comparison of expected and minimum properties,

11. stress-strain behavior,

12. relation between room-temperature yield strength and hardness,

13. comparison of $0.2 \%$ yield strength data with data on other heats, and

14. comparison of $0.2 \%$ yield and ultimate tensile strengths with vendorcertified mechanical property data.

\section{MATERIALS AND EXPERIMENTAL DETAILS}

\section{Melting Details}

The reference heat of type 316 stainless steel was air melted in a 200-ton electric furnace at Republic Steel's No. 4 melt shop of the Steel Division, Canton, Ohio. The heat was made in February 1974 and was intended to meet the ORNL-MC-316 specification. ${ }^{13}$ The ladle analysis in Table 1 shows that the chemical analysis of the reference heat was in 
Table 1. Comparison of Ladle Chemical Analysis for the Reference Heat (8092297) of Type 316 Stainless Steel with ORNL, RDT, and Nuclear Systems Materials Handbook Specifications

\begin{tabular}{|c|c|c|c|c|}
\hline \multirow{2}{*}{$\begin{array}{l}\text { Chemical } \\
\text { Element }\end{array}$} & \multicolumn{4}{|c|}{ Content, wt \% } \\
\hline & $\begin{array}{c}\mathrm{RDT} \\
\text { Standards }\end{array}$ & NSMH & ORNL-MC-316 & $\begin{array}{l}\text { Ladle } \\
\text { Analyses }\end{array}$ \\
\hline c & $0.04-0.10$ & $0.08 \max$ & $0.050-0.080$ & 0.057 \\
\hline Mn & $2 \max$ & $2.00 \max$ & $1.50-2.00$ & 1.86 \\
\hline $\mathrm{P}$ & $0.030 \max$ & $0.045 \max ^{a}$ & $0.02-0.03$ & 0.024 \\
\hline s & $0.030 \mathrm{max}$ & $0.030 \max$ & $0.010-0.025$ & 0.019 \\
\hline Si & $0.75 \max$ & $1.00 \max ^{b}$ & $0.030-0.60$ & 0.58 \\
\hline $\mathrm{Ni}$ & $11.00-14.00$ & $10.00-14.00^{c}$ & $13.25-13.75$ & 13.48 \\
\hline $\mathrm{Cr}$ & $16.00-18.00$ & $16.00-18.00$ & $16.5-17.5$ & 17.25 \\
\hline Mo & $2.0-3.0$ & $2.00-3.00$ & $2.20-2.50$ & 2.34 \\
\hline Co & None & None & $0.10 \max$ & 0.02 \\
\hline $\mathrm{Cu}$ & None & None & $0.20 \max$ & 0.10 \\
\hline $\mathrm{N}$ & None & None & $0.05 \max$ & 0.03 \\
\hline $\mathrm{Nb}+\mathrm{Ta}$ & $\mathrm{d}$ & None & $0.020 \max$ & e \\
\hline B & None & None & $0.003 \max$ & 0.0005 \\
\hline $\mathrm{Ti}$ & None & None & $0.020 \max$ & 0.02 \\
\hline $\mathrm{Pb}$ & & & & 0.003 \\
\hline Sn & & & & 0.004 \\
\hline A1 & & & Not required & \\
\hline
\end{tabular}

${ }^{a} 0.030$ max for seamless pipe (SA 376).

$b_{0.75} \max$ for seamless pipe (SA 376).

$c_{11.00-14.00}$ for seamless pipe (SA 376).

$\mathrm{d}_{\mathrm{The}} \mathrm{Nb}+\mathrm{Ta}$ content shall be not less than ten times the carbon content and not more than $1.00 \%$.

$\mathrm{e}_{\text {Not detectable at }}$ level of $0.01 \mathrm{wt} \%$. 
close agreement with ORNL-MC-316, RDT, and Nuclear Systems Materials Handbook ${ }^{14}$ (NSMH) specifications. Various product forms were made from this heat, herein we describe the work being carried out at ORNL on mechanical property characterization of these products.

Fabrication Processes

The product forms being studied include plate, pipe, and bar of various sizes, 1isted in Table 2. They were fabricated as follows:

Plate Product - The 16-mm-thick plates were produced from 635- by 685-mm ingots. These ingots were bloomed to 457 by $102 \mathrm{~mm}$. Each bloom was cut into three sections and each section was hot rolled to plate approximately $100-$ by 200-mm 1ong. The 25- and 51-mm-thick plates were processed similarly, except that the ingot size was 508 by $1041 \mathrm{~mm}$ and it was bloomed to $863-$ by $127-\mathrm{mm}$ slabs. All plates were solution annealed at $1065 \pm 30^{\circ} \mathrm{C}\left(1950 \pm 50^{\circ} \mathrm{F}\right)$ before shipping.

Pipe Products - A11 pipes except 406- and 711-mm-diam pipe were produced at the Ellwood City works of U.S. Steel. Seamless pipe was produced by the Mannesman process, in which the round, after being heated to temperature, is squeezed between rotating rolls while being rotated at high speed and drawn through the mill over a piercing point located between the rolls. After piercing, the pipe is reduced by either plug rolling and reeling or bar rolling and sizing. The 406- and 711-mm-diam by 10-mm-wall pipes were produced at Rollmet by roll extrusion, a reduction process at room temperature that involves intermediate annealing. The 406-mm pipe was produced by external roll extrusion in which the die ring works from the outside, increasing the length and decreasing the thickness while maintaining constant inside diameter. The 711-mm-diam by $10-\mathrm{mm}$-wall pipe was produced by internal roll extrusion, in which solid rollers inserted within the forged ring apply pressure on the internal surfaces, while a tight-fitting external die ring maintains the outside diameter within very close tolerances. All pipe was solution annealed at $1065 \pm 30^{\circ} \mathrm{C}\left(1950 \pm 50^{\circ} \mathrm{F}\right)$. 
Table 2. Product Form, Size, and Grain Sizes of Various Products of Reference Heat (8092297) of Type 316 Stainless Steel

\begin{tabular}{|c|c|c|c|c|c|c|c|c|c|}
\hline \multirow{4}{*}{$\begin{array}{l}\text { Product } \\
\text { Form }\end{array}$} & \multirow{4}{*}{$\begin{array}{c}\text { Size } \\
\operatorname{mm}(i n .)\end{array}$} & \multicolumn{8}{|c|}{ Grain Size, ASTM ( $\mu \mathrm{m})$} \\
\hline & & \multicolumn{4}{|c|}{ As-Recelved Condition } & \multicolumn{4}{|c|}{ Reannealed Condition } \\
\hline & & \multicolumn{2}{|c|}{ Longitudinal } & \multicolumn{2}{|c|}{ Transverse } & \multicolumn{2}{|c|}{ Longitudinal } & \multicolumn{2}{|c|}{ Transverse } \\
\hline & & $\begin{array}{l}\text { With } \\
\text { Twins }\end{array}$ & $\begin{array}{l}\text { Without } \\
\text { Twins }\end{array}$ & $\begin{array}{l}\text { With } \\
\text { Twins }\end{array}$ & $\begin{array}{l}\text { Without } \\
\text { Twins }\end{array}$ & $\begin{array}{l}\text { With } \\
\text { Twins }\end{array}$ & $\begin{array}{l}\text { Without } \\
\text { Twins }\end{array}$ & $\begin{array}{l}\text { With } \\
\text { Twins }\end{array}$ & $\begin{array}{l}\text { Without } \\
\text { Twins }\end{array}$ \\
\hline Plate & $16(5 / 8)$ & $6.2(37)$ & $5.3(50)$ & $6.4(34)$ & $5.4(48)$ & $5.5(46)$ & $3.6(90)$ & $5.8(41)$ & $5.0(56)$ \\
\hline Plate & 25 (1) & $6.2(36)$ & $4.2(74)$ & $6.1(38)$ & $4.2(74)$ & $6.3(35)$ & $4.2(74)$ & $5.5(47)$ & $4.2(74)$ \\
\hline Plate & $51(2)$ & $5.3(50)$ & $4.2(74)$ & $4.8(59)$ & $4.0(79)$ & $5.3(50)$ & $4.2(74)$ & $4.8(59)$ & $3.8(85)$ \\
\hline Pipe ${ }^{a}$ & $\begin{array}{l}114 \text { OD } \times 13 \text { wal1 } \\
(41 / 2 \times 1 / 2)\end{array}$ & & & $\left\{\begin{array}{c}\text { not } \operatorname{me} \\
6.3^{(35)} \\
\text { not me }\end{array}\right.$ & $\begin{array}{l}\text { rable } \\
5.0(56) \\
\text { rable }\end{array}$ & & & $\begin{array}{l}\text { not me } \\
6.1 \quad(38) \\
5.1 \quad(53)\end{array}$ & $\begin{array}{l}\text { rable } \\
4.2(74) \\
2.5(130)\end{array}$ \\
\hline Pipe ${ }^{a}$ & $\begin{aligned} & 219 \text { OD } \times 13 \text { wall } \\
&(85 / 8 \times 1 / 2)\end{aligned}$ & & & $\begin{cases}6.0 & (39) \\
6.6 & (32) \\
6.6 & (32)\end{cases}$ & $\begin{array}{l}4.0(78) \\
4.8(59) \\
4.4(68)\end{array}$ & & & $\begin{array}{ll}6.3 & (35) \\
6.0 & (40) \\
6.2 & (37)\end{array}$ & $\begin{array}{ll}4.8 & (59) \\
4.8 & (59) \\
4.2 & (73)\end{array}$ \\
\hline Pipe $^{a}$ & $\begin{array}{l}406 \text { oD } \times 10 \text { wall } \\
(16 \times 0.4)\end{array}$ & & & $\begin{cases}6.1 & (38) \\
6.1 & (38) \\
6.1 & (38)\end{cases}$ & $\begin{array}{ll}4.8 & (59) \\
3.8(85) \\
4.2 & (73)\end{array}$ & & & $\begin{array}{ll}6.1 & (38) \\
5.3 & (50) \\
6.2 & (37)\end{array}$ & $\begin{array}{l}4.0(78) \\
3.5(93) \\
4.4 \quad(68)\end{array}$ \\
\hline $\mathrm{Pipe}^{\mathrm{a}}$ & $\begin{array}{l}711 \text { oD } \times 10 \text { wal1 } \\
(28 \times 0.4)\end{array}$ & & & $\begin{cases}6.5 & (36) \\
5.1 & (53) \\
5.3 & (51)\end{cases}$ & $\begin{array}{ll}4.0 & (78) \\
3.5 & (93) \\
3.5 & (93)\end{array}$ & & & $\begin{array}{ll}5.4 & (48) \\
5.5 & (45) \\
5.0 & (56)\end{array}$ & $\begin{array}{ll}3.7 & (85) \\
3.5 & (93) \\
2.9 & (115)\end{array}$ \\
\hline Bar & 25 (1) & $6.2(37)$ & $4.2(73)$ & $6.0(40)$ & $4.2(73)$ & $6.3(35)$ & $3.7(86)$ & $6.2(37)$ & $4.4(68)$ \\
\hline $\mathrm{Bar}^{\mathrm{a}}$ & $51(2)$ & $\{5.5(46)$ & $3.1(108)$ & $\begin{array}{ll}6.1 & (38) \\
5.7 & (44)\end{array}$ & $\begin{array}{l}4.4(68) \\
3.5(93)\end{array}$ & $5.4(48)$ & $3.5(92)$ & $\begin{array}{l}5.9(41) \\
4.8(58)\end{array}$ & $\begin{array}{l}4.0(79) \\
3.2(102)\end{array}$ \\
\hline $\mathrm{Bar}{ }^{\mathrm{a}}$ & $64(2.5)$ & $\{5.7(44)$ & $4.0(78)$ & $\begin{array}{ll}5.7 & (44) \\
6.0 & (40)\end{array}$ & $\begin{array}{l}4.0(78) \\
3.5(93)\end{array}$ & $5.9(41)$ & $3.5(92)$ & $\begin{array}{l}5.6(45) \\
5.9(41)\end{array}$ & $\begin{array}{l}4.0(78) \\
3.7(85)\end{array}$ \\
\hline
\end{tabular}

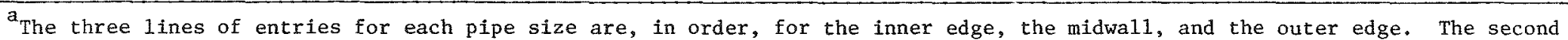
transverse values for the larger bars are for the outer edge. 
Bar Products - All bars were produced from 635- by 689-mm ingots, bloomed to 229 by $197 \mathrm{~mm}$, cut into multiples, and hot-rolled through a series of intermediate breakdowns to slightly above final product diameter. All bars were solution annealed at $1065 \pm 30^{\circ} \mathrm{C}\left(1950 \pm 50^{\circ} \mathrm{F}\right)$ and subsequently straightened, turned, and ground to final size. The bars being investigated are 25,51 , and $64 \mathrm{~mm}(1,2$, and $2.5 \mathrm{in.})$ in diameter.

Chemical Analysis

The vendor analyses along with the ORNL check analyses on severa1 products are summarized in Table 3. For comparison the ORNL-MC-3I6 specification and ladle analysis are also included. The chemical analysis of all ten products is essentially the same.

\section{Microstructure}

Optical microstructure of specimens etched electrolytically with $10 \% \mathrm{HNO}_{3} / \mathrm{H}_{2} \mathrm{O}$ solution is shown in Figs. I through 10 for various product forms of the reference heat in both as-received and reannealed conditions. Grain sizes were measured ${ }^{I} 5$ from these micrographs and are summarized in Table 2. Grain sizes for pipe product were measured at the inner surface, midwall, and outer surface. The grain size at the outer surface was generally larger than at the other two locations for both as-received and reannealed conditions. The outer surface of the 51- and 64-mm bars also showed coarser grain size in both mill- and laboratory-annealed conditions. In general, none of the products showed unusual or excessive grain growth on reannealing for $0.5 \mathrm{hr}$ at $1065^{\circ} \mathrm{C}\left(1950^{\circ} \mathrm{F}\right)$. The backup work to select the reannealing treatment is presented in Appendix A.

\section{Microhardness Studies}

Previous studies ${ }^{1,3,9}$ on product form characterization of type 304 stainless steel indicated that the bars varied more in hardness across the section than did other products. Therefore, bar products of the reference heat of type 316 stainless steel were also subjected to careful hardness traverses. These are shown in Fig. 11. The as-received 51- and 
Table 3. Summary of Chemical Analysis for Variance Product Forms of Reference Heat (8092297) of Type 316 Stainless Steel

\begin{tabular}{|c|c|c|c|c|c|c|c|c|c|c|c|c|c|c|c|}
\hline \multirow{4}{*}{$\begin{array}{r}\text { Chemica1 } \\
\text { Element }\end{array}$} & \multirow{4}{*}{$\begin{array}{l}\text { ORNL-MC-316 } \\
\text { Specification }\end{array}$} & \multirow{4}{*}{$\begin{array}{c}\text { Ladle } \\
\text { Analysis }\end{array}$} & \multicolumn{13}{|c|}{ Concentration, wt \% } \\
\hline & & & \multicolumn{10}{|c|}{ Vendor Analysis for Various Product Forms and Size in mm } & \multicolumn{3}{|c|}{ ORNL Check Analys 15} \\
\hline & & & \multicolumn{3}{|c|}{ Plates } & \multicolumn{4}{|c|}{ Pipe } & \multicolumn{3}{|c|}{ Bar } & \multicolumn{3}{|l|}{ P1ate } \\
\hline & & & 16 & $25^{\mathrm{a}}$ & $51^{\mathrm{b}}$ & $13 \times 114^{c}$ & $13 \times 219^{d}$ & $10 \times 406^{d}$ & $10 \times 711^{\mathrm{e}}$ & 25 & 51 & 64 & 16 & $10 \times 406$ & $10 \times 711$ \\
\hline c & $0.050-0.080$ & 0.057 & 0.060 & $0.059-0.060$ & $0.062-0.065$ & $0.061-0.065$ & $0.061-0.68$ & $0.01-0.065$ & $0.065-0.07$ & 0.060 & 0.051 & 0.054 & 0.0645 & 0.064 & 0.066 \\
\hline$M_{n}$ & $1.50-2.00$ & 1.86 & 1.88 & $1.84-1.86$ & $1.82-1.85$ & 1.86 & $1.85-1.87$ & $1.75-1.81$ & $1.77-1.84$ & 1.85 & 1.87 & 1.86 & & 1.75 & 1.6 \\
\hline $\mathrm{p}$ & $0.02-0.03$ & 0.024 & 0.023 & 0.024 & $0.022-0.024$ & $0.023-0.024$ & $0.026-0.027$ & $0.04-0.20$ & $0.015-0.02$ & 0.024 & 0.030 & 0.024 & 0.022 & 0.020 & 0.022 \\
\hline $\mathrm{s}$ & $0.01-0.025$ & 0.019 & 0.020 & 0.018 & $0.018-0.020$ & 0.018 & 0.018 & $0.010-0.013$ & $0.012-0.014$ & 0.019 & 0.018 & 0.019 & 0.0188 & 0.018 & 0.019 \\
\hline$s_{1}$ & $0.30-0.60$ & 0.58 & 0.62 & $0.57-0.58$ & $0.57-0.58$ & $0.57-0.59$ & $0.56-0.58$ & $0.58-0.60$ & $0.55-0.58$ & 0.58 & 0.53 & 0.60 & 0.51 & 0.65 & 0.62 \\
\hline $\mathrm{N}_{1}$ & $13.25-13.75$ & 13.48 & 13.40 & $13.40-13.45$ & $13.30-13.40$ & $13.50-13.60$ & $13.48-13.50$ & $12.80-12.95$ & $12.65-12.80$ & 13.70 & 13.45 & 13.50 & 13.86 & 13.50 & 13.3 \\
\hline $\mathrm{cr}$ & $16.5-17.5$ & 17.25 & 17.30 & 17.15 & $16.90-17.15$ & $17.10-17.20$ & $17.07-17.20$ & $17-50$ & $17.18-17.40$ & 17.10 & 17.28 & 17.19 & 16.46 & 17.50 & 16.8 \\
\hline Mo & $2.20-2.50$ & 2.34 & 2.34 & 2.34 & $2.29-2.34$ & 2.34 & $2.32-2.35$ & $2.34-2.41$ & $2.18-2.37$ & 2.35 & 2.32 & 2.34 & 2.44 & 2.38 & 2.38 \\
\hline $\mathrm{T}_{1}$ & $0.020 \max$. & 0.02 & $<0.01$ & $<0.01$ & $<0.01$ & 0.020 & $0.01-0.02$ & $<0.01-0.01$ & $<0.01-0.01$ & 0.01 & 0.02 & 0.02 & $<0.01$ & $<0.01$ & $<0.01$ \\
\hline Co & $0.10 \max$. & 0.02 & 0.02 & 0.02 & 0.01 & $<0.01$ & $<0.01$ & & & 0.02 & 0.02 & 0.02 & 0.01 & & \\
\hline $\mathrm{s}$ & $0.05 \max$. & 0.03 & 0.034 & $0.031-0.033$ & $0.031-0.033$ & $0.031-0.032$ & $0.031-0.032$ & & & 0.032 & 0.030 & 0.03 & 0.0305 & 0.05 & 0.03 \\
\hline B & $0.003 \max$. & 0.0005 & 0.0005 & $0.0005-0.0006$ & $0.0005-0.0006$ & 0.0005 & $0.0004-0.0005$ & & $<0.01-<0.001$ & 0.0005 & 0.0005 & 0.0005 & 0.0005 & 0.0003 & 0.0015 \\
\hline $\mathrm{Nb}+\mathrm{Ta}$ & $0.020 \max$ & $<0.01$ & $<0.01$ & $<0.01$ & $<0.01$ & $<0.01$ & $<0.01$ & $<0.05-<0.01$ & $<0.05<0.01$ & $<0.01$ & $<0.01$ & $<0.01$ & $0.10^{\mathrm{f}}$ & $<0.05$ & $<0.05$ \\
\hline $\mathrm{Al}$ & Not Required & & & & & $0.015-0.017$ & $0.014-0.017$ & $<0.01<0.001$ & & 0.023 & & & $<0.02$ & & \\
\hline 0 & & & & & & & & & & & & & 0.0043 & & \\
\hline H & & & & & & & & & & & & & 0.0007 & & \\
\hline w & & & & & & & & & & & & & 0.0020 & & \\
\hline
\end{tabular}

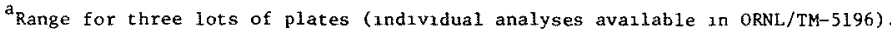

bange for four lots of plates (1ndividual analyses avallable in ORAL/TM-5196).

${ }^{c}$ Range for six analyses on three different lots (individual analyses avallable in $0 R N L / F M-5196$ ).

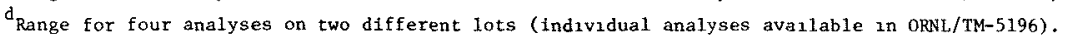

${ }^{e_{\text {Range }}}$ for three analyses on three different lots (Individual analyses avallable in ORNL/TM-5196).

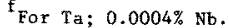



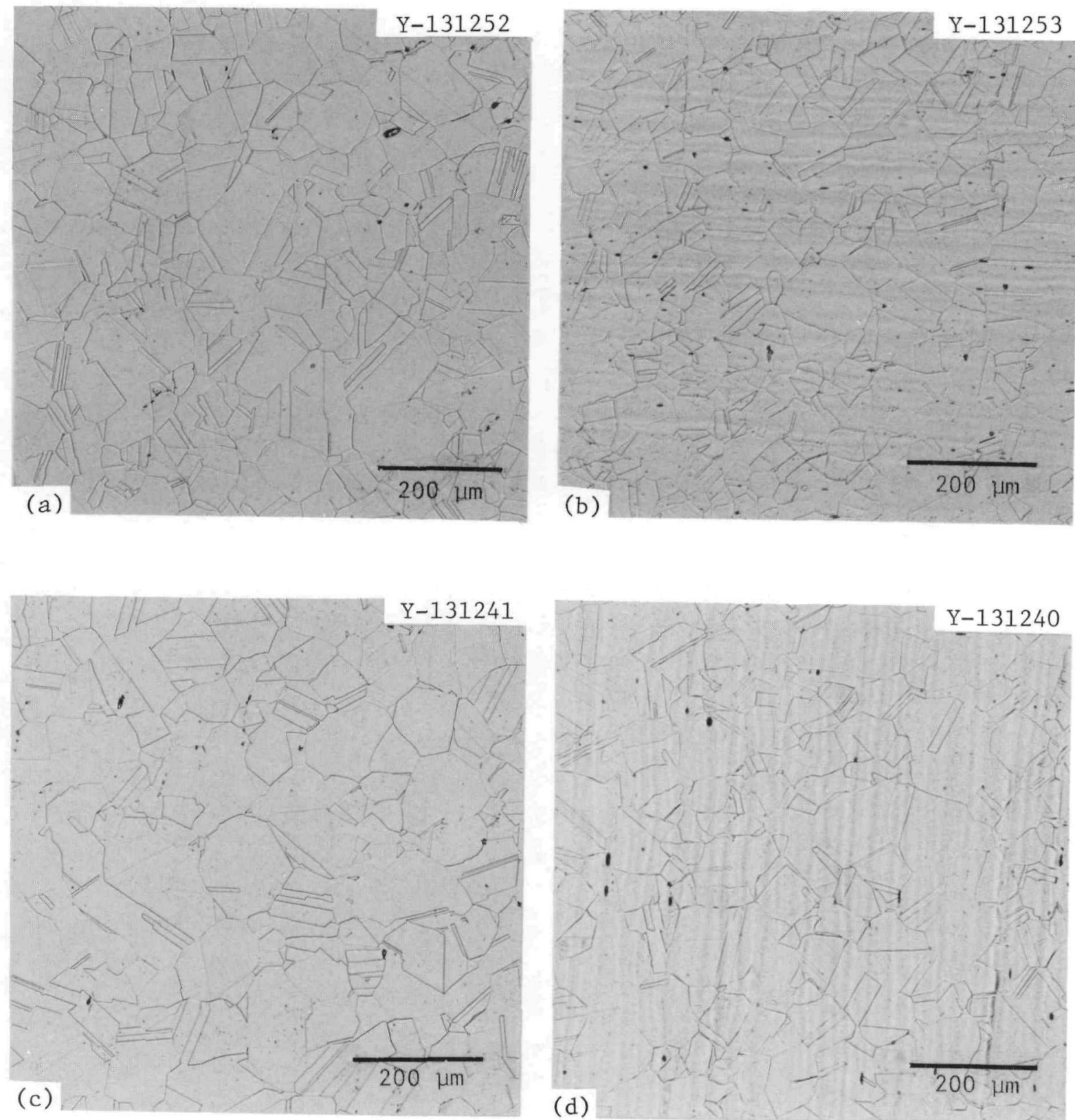

Fig. 1. Optical Microstructure of 16-mm Plate of the Reference Heat (8092297) of Type 316 Stainless Steel. (a), (b) Longitudinal and transverse sections, as received. (c), (d) Longitudinal and transverse sections, reannealed. Scales are 0.0079 in. Plate is 5/8 in. 

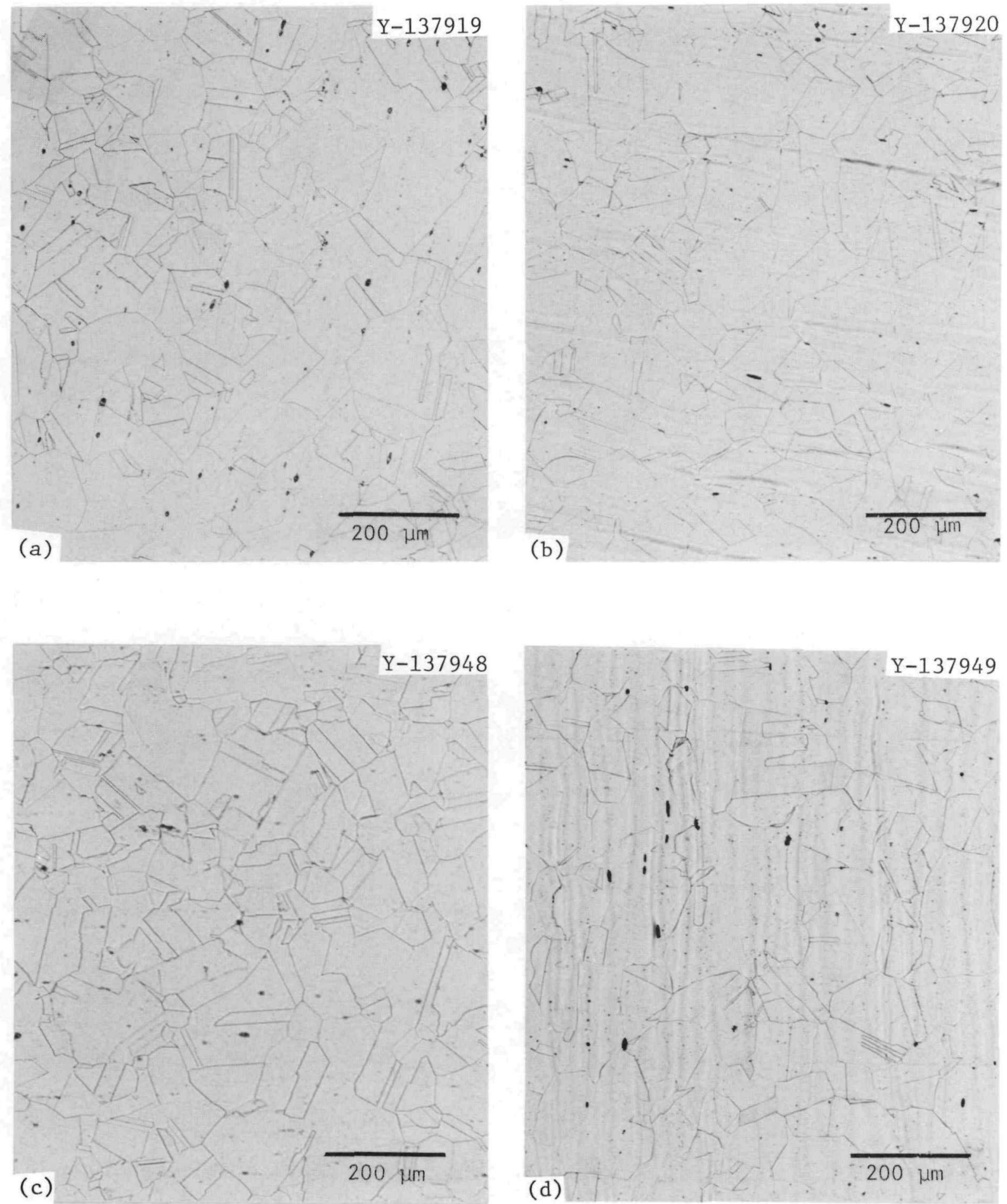

Fig. 2. Optical Microstructure of 25-mm Plate of the Reference Heat (8092297) of Type 316 Stainless Steel. (a), (b) Longitudinal and transverse sections, as received. (c), (d) Longitudinal and transverse sections, reannealed. Scales are 0.0079 in. Plate is 1 in. 

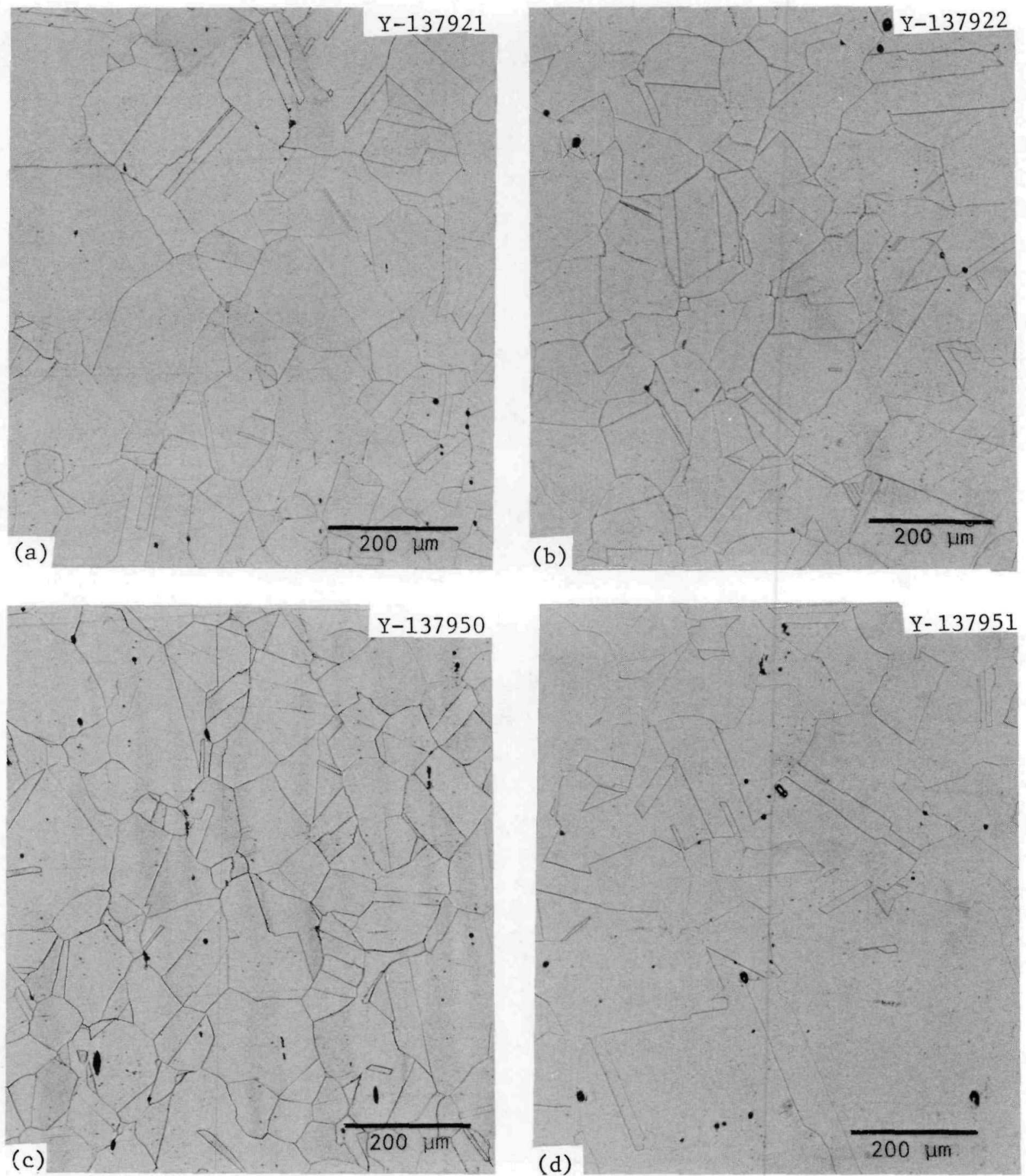

Fig. 3. Optical Microstructure of 51-mm Plate of the Reference Heat (8092297) of Type 316 Stainless Steel. (a), (b) Longitudinal and transverse sections, as received. (c), (d) Longitudinal and transverse sections, reannealed. Scales are 0.0079 in. Plate is 2 in. 

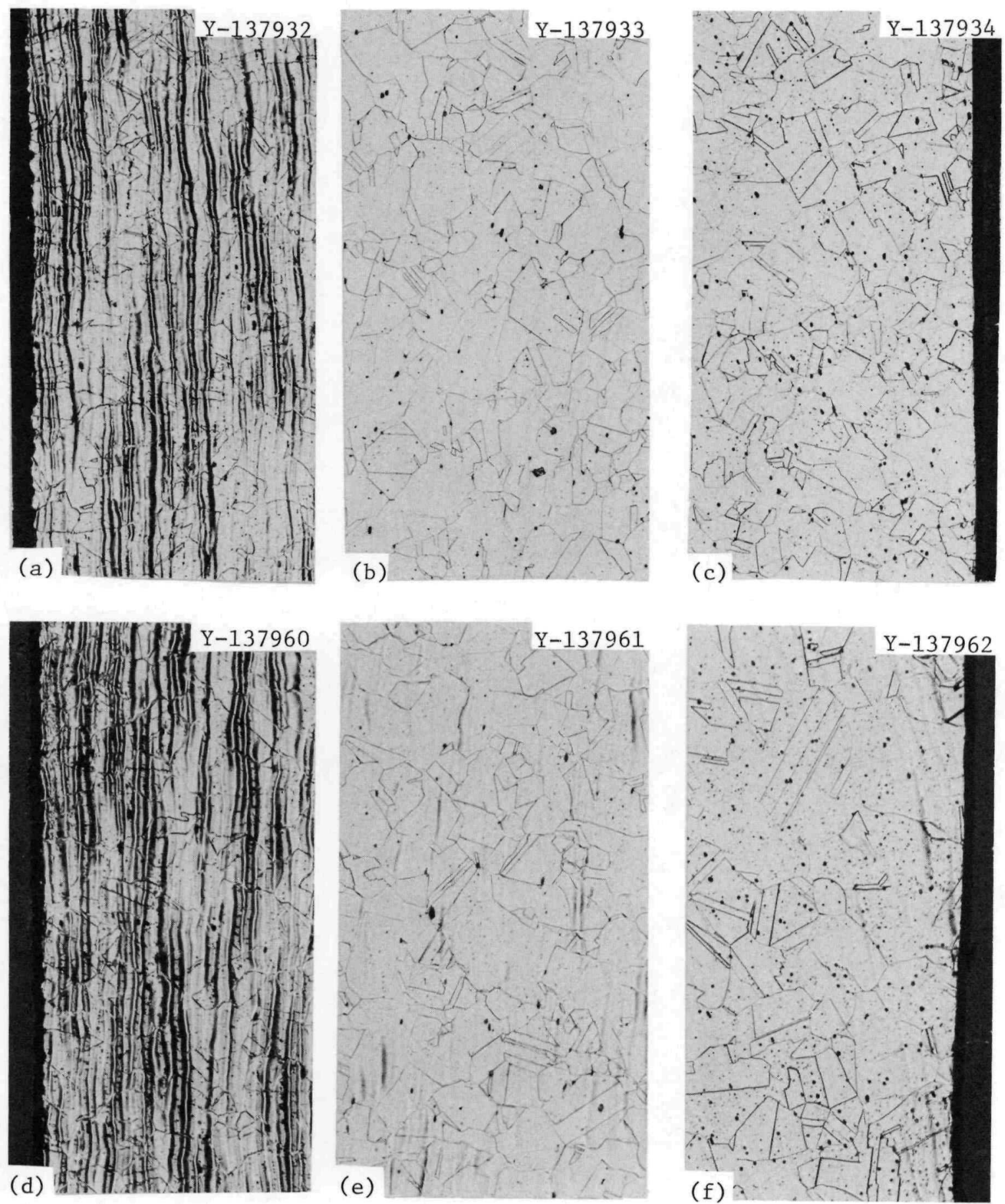

Fig. 4. Optical Microstructure of 13- by 114-mm Pipe of the Reference Heat (8092297) of Type 316 Stainless Steel. (a) Inner surface, (b) midwall, and (c) outer surface, as received. (d) Inner surface, (e) midwall, and (f) outer surface, reannealed. Scale is 0.0079 in. Pipe is $1 / 2$ by $41 / 2$ in. 

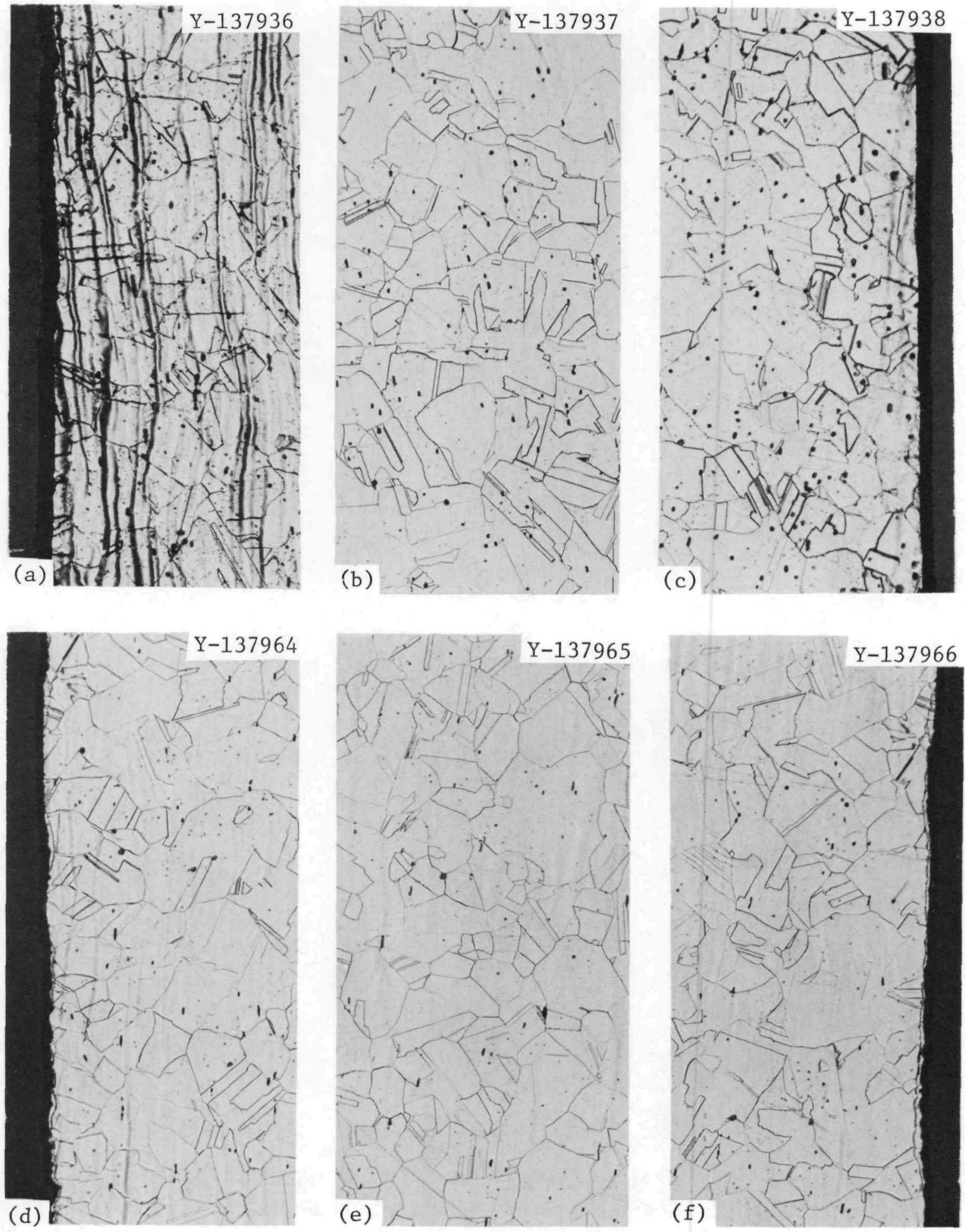

Fig. 5. Optical Microstructure of 13- by 219-mm Pipe of the Reference Heat (8092297) of Type 316 Stainless Steel. (a) Inner surface, (b) midwall, and (c) outer surface, as received. (d) Inner surface, (e) midwall, and (f) outer surface, reannealed. Scale is 0.0079 in. Pipe is $1 / 2$ by $8 / 8$ in. 

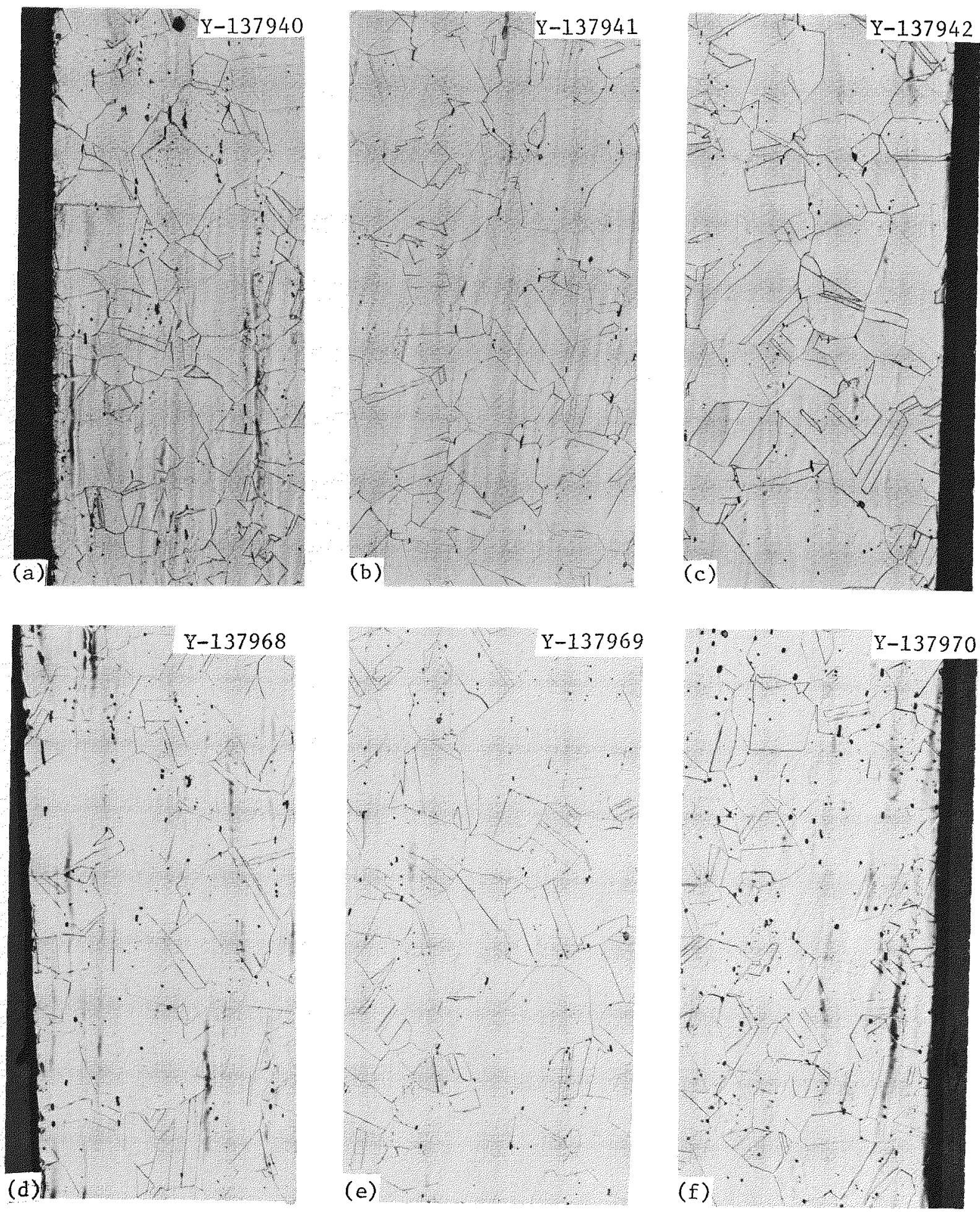

Fig. 6. Optical Microstructure of 10- by 406-mm Pipe of the Reference Heat (8092297) of Type 316 Stainless Steel. (a) Inner surface, (b) midwal1, and (c) outer surface, as received. (d) Inner surface, (e) midwall, and (f) outer surface, reannealed. Scale is 0.0079 in. Pipe is 0.4 by 16 in. 

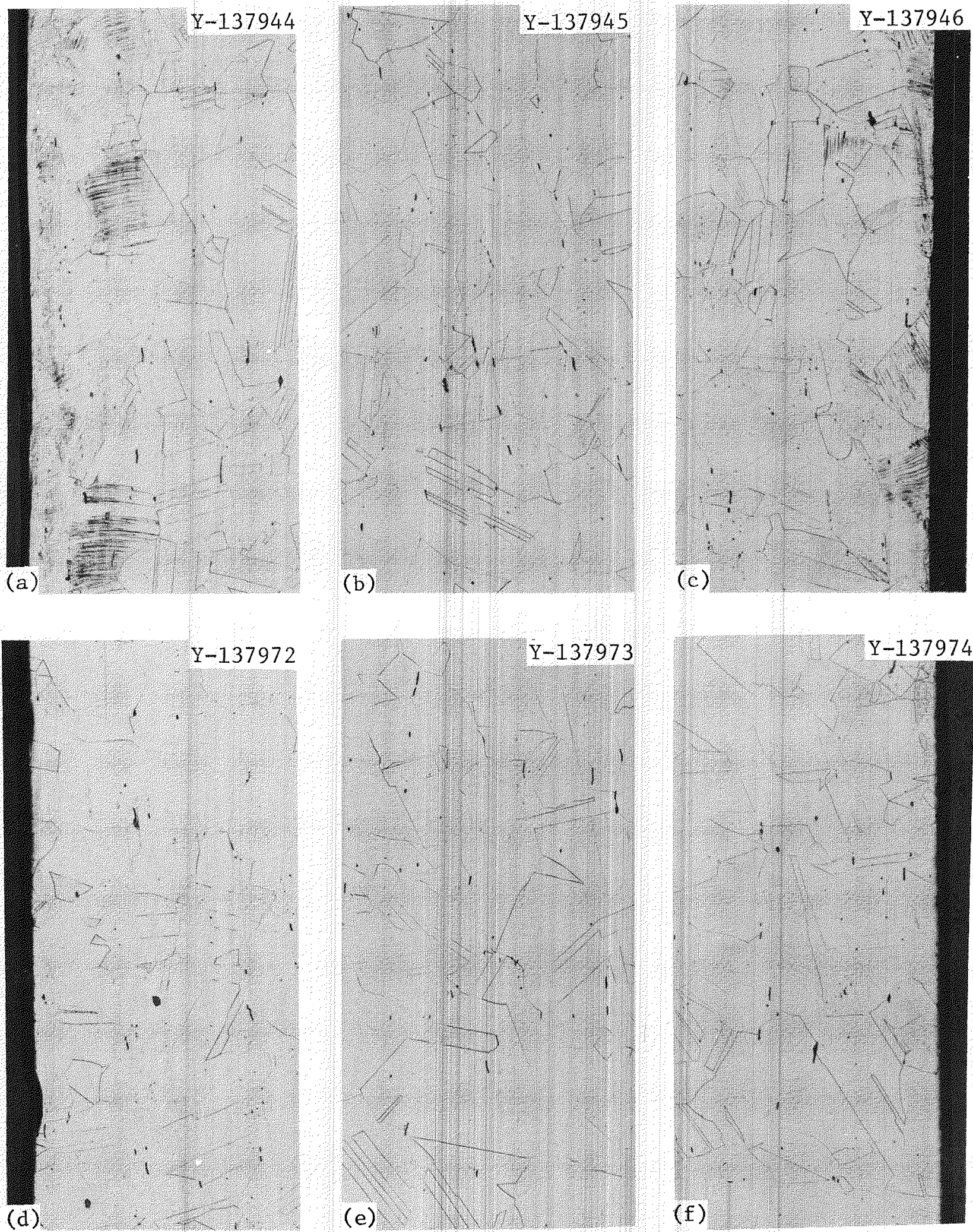

Fig. 7. Optical Microstructure of 10- by 711-mm Pipe of the Reference Heat (8092297) of Type 316 Stainless Steel. (a) Inner surface, (b) midwall, and (c) outer surface, as received. (d) Inner surface, (e) midwa11, and (f) outer surface, reannealed. Scale is 0.0079 in. Pipe is 0.4 by 28 in. 


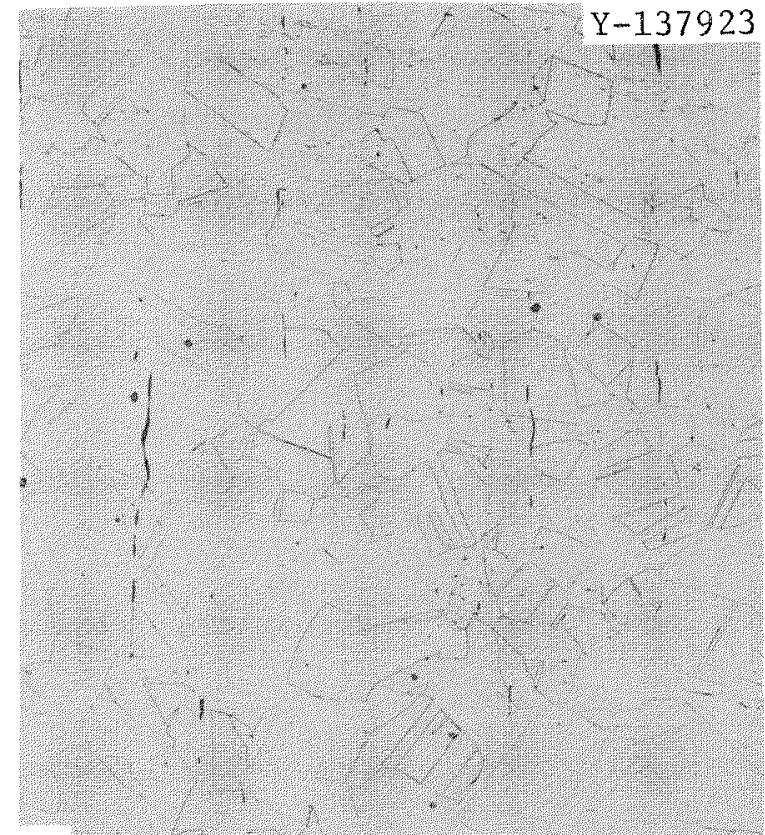

(a)

$$
200 \mu \mathrm{m}
$$

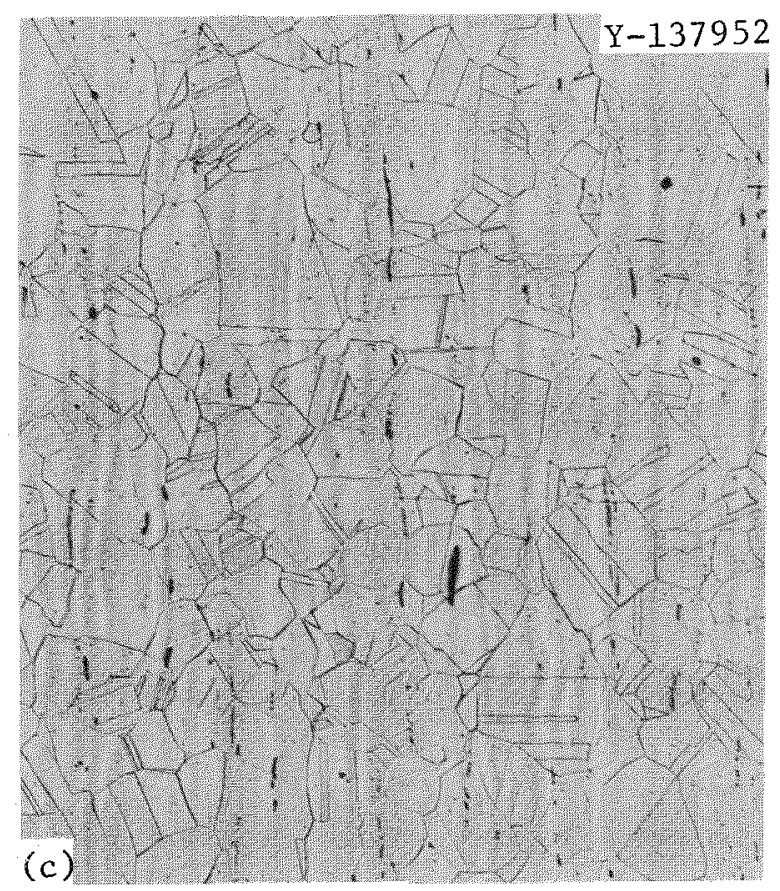

(b)
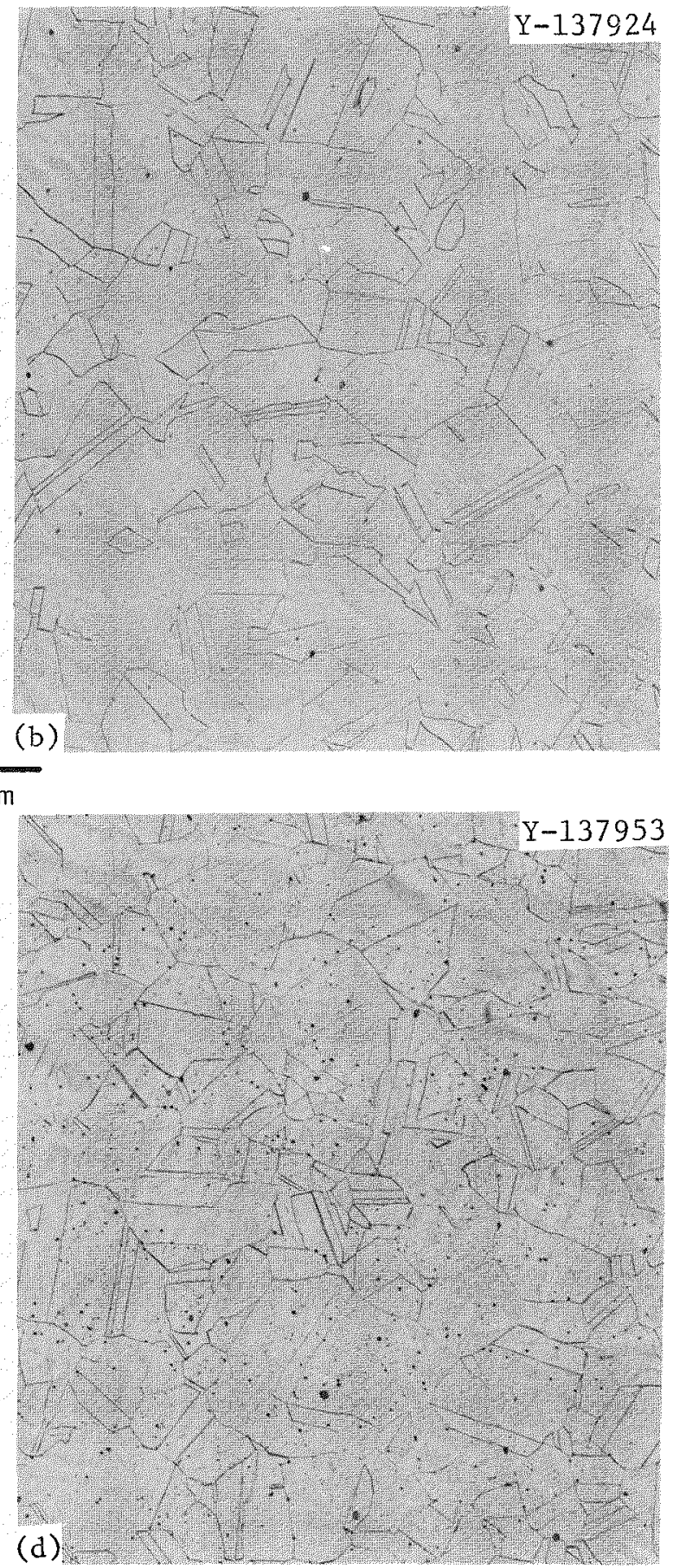

Fig. 8. Optical Microstructure of 25-mm Bar of the Reference Heat (8092297) of Type 316 Stainless Steel. (a), (b) Longitudinal and transverse sections, as received. (c), (d) Longitudinal and transverse sections, reannealed. Scale is 0.0079 in. Bar is 1 in. 

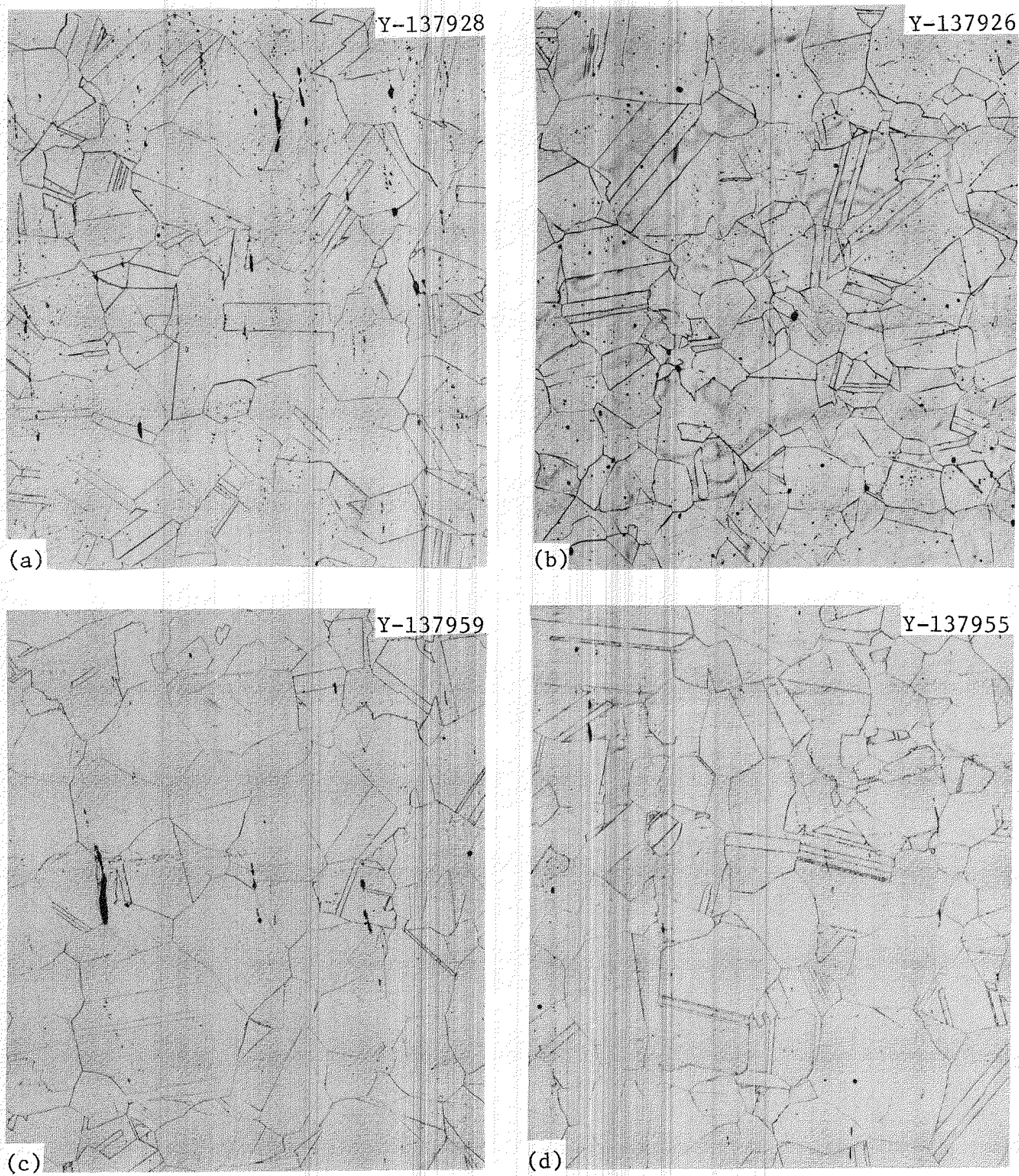

Fig. 9. Optical Microstructure of 51-mm Bar of the Reference Heat (8092297) of Type 316 Stainless Steel. (a), (b) Longitudinal and transverse sections, as received. (c), (d) Longitudinal and transverse sections, reannealed. Scale is $0.0079 \mathrm{in}$. Bar is 2 in. 

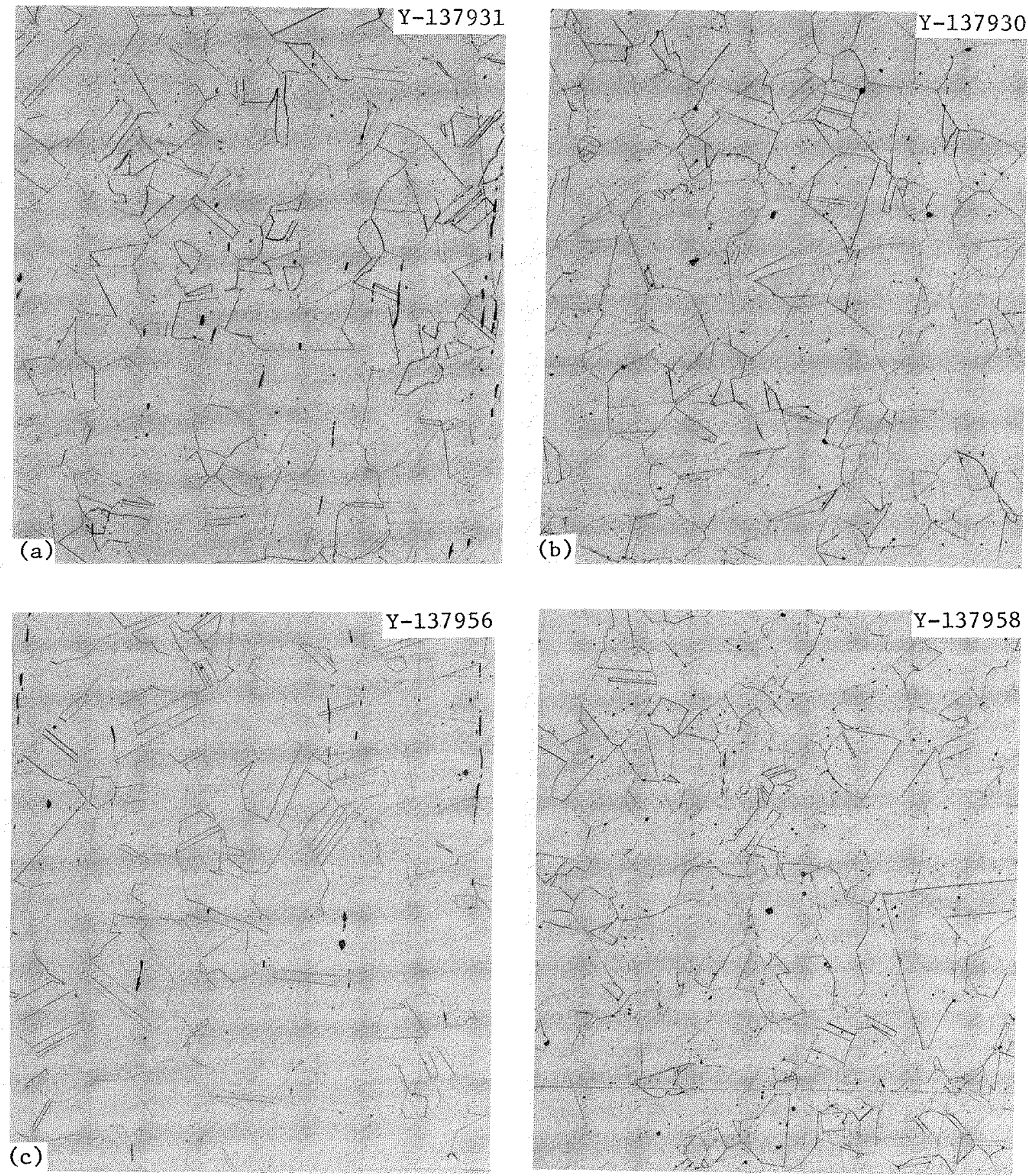

Fig. 10. Optical Microstructure of 64-mm Bar of the Reference Heat (8092297) of Type 316 Stainless Steel. (a), (b) Longitudina1 and transverse sections, as received. (c), (d) Longitudinal and transverse sections, reannealed. Scale is $0.0079 \mathrm{in.} \mathrm{Bar}$ is $2.5 \mathrm{in.}$ 

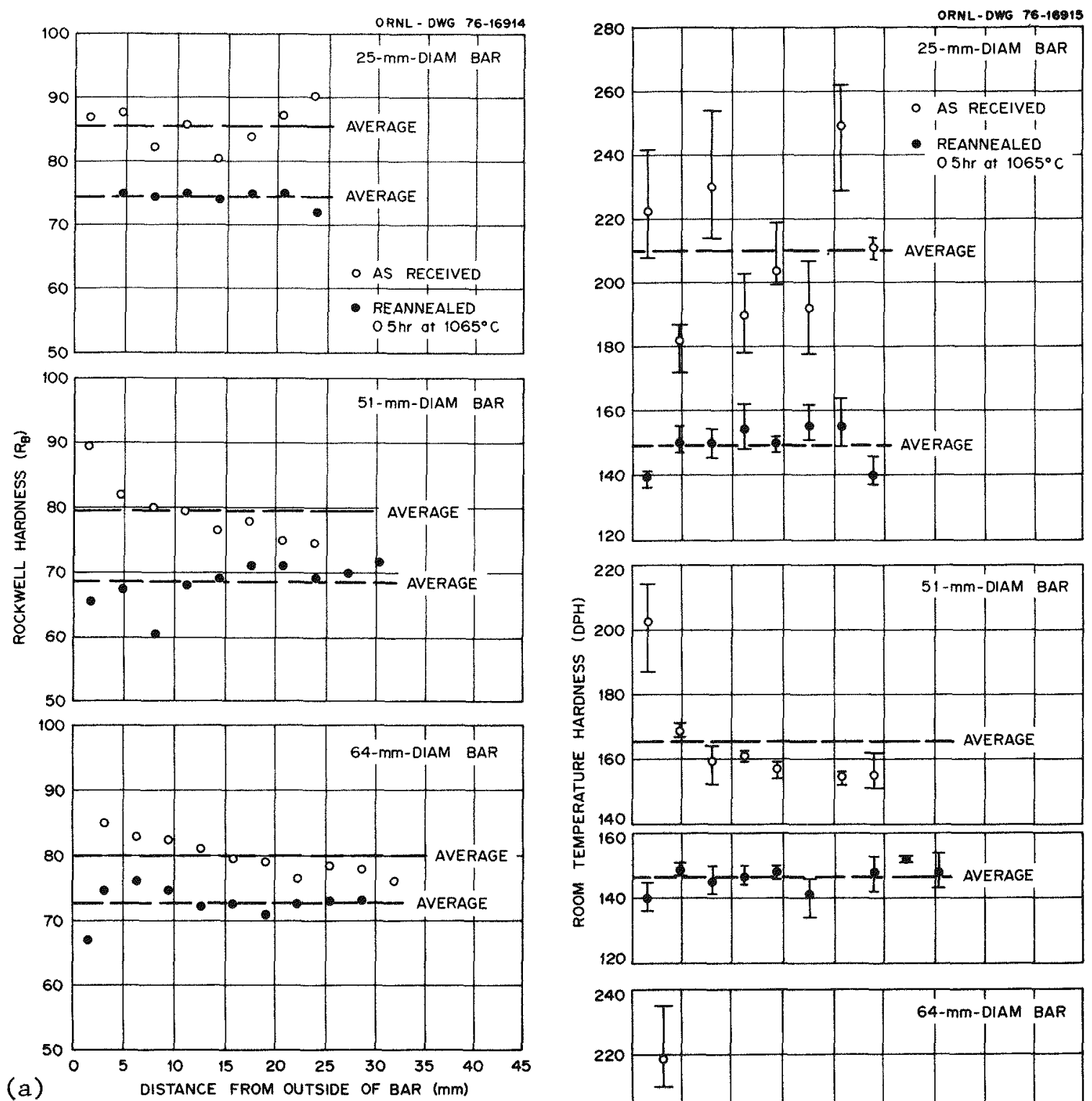

(a)

Fig. 11. Hardness Profiles for Bars of the Reference Heat (8092297) of Type 316 Stainless Stee1. (a) Rockwe11 hardness number. (b) Microhardness. To convert: $1 \mathrm{~mm}=0.03937 \mathrm{in}$.

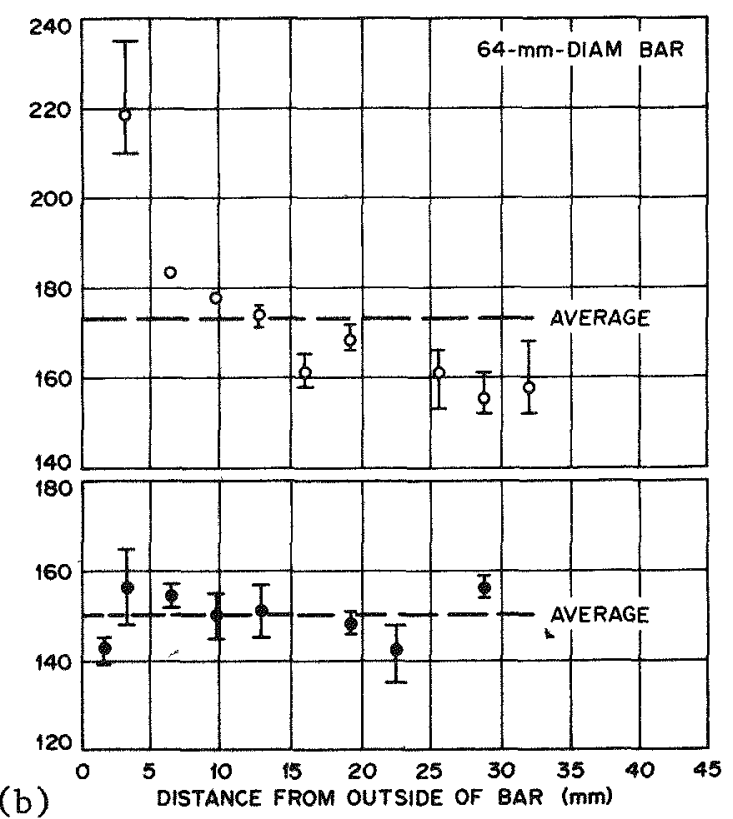

(b) 
64-mm-diam bars showed consistent hardness gradients. The 25-mm-diam bar did not, but it showed a large variation in hardness, indicating a highly inhomogenous product. Reannealing for $0.5 \mathrm{hr}$ at $1065^{\circ} \mathrm{C}$ removed the hardness gradients and variations and lowered the average values.

\section{Tensile Test Specimen}

The test specimen used in this study is shown in Fig. 12. The specimens were lathe-machined. Cut-up diagrams for tensile specimens from various product forms are shown in Fig. 13.

A set of 24 specimens was machined from each product form of the reference heat except 16-mm (5/8-in.) plate, from which 150 specimens were machined. To determine the uniformity of each product form, Rockwel1 hardness was measured on both ends of each specimen. The hardness data so obtained were plotted as hardness distribution histograms for each product and are shown in Figs. 14 through 16. The average hardness values for each product are summarized in Table 4. This table also includes average values from data plotted in Fig. 11 and some additional data obtained on reannealed specimens of various product forms. The following are some comments from Figs, 14 through 16 with the data sumarized in Table 4.

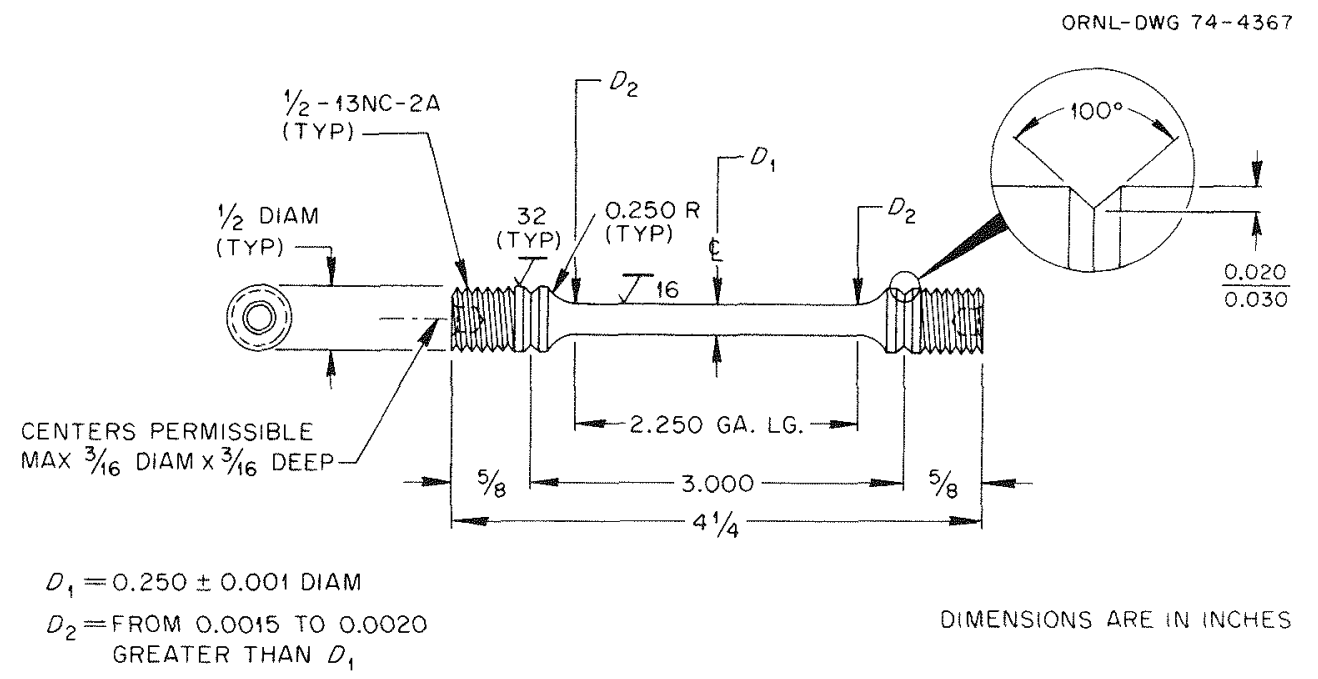

Fig. 12. Tensile Test Specimen. To convert dimensions to millimeters, multiply by 25.4 . 


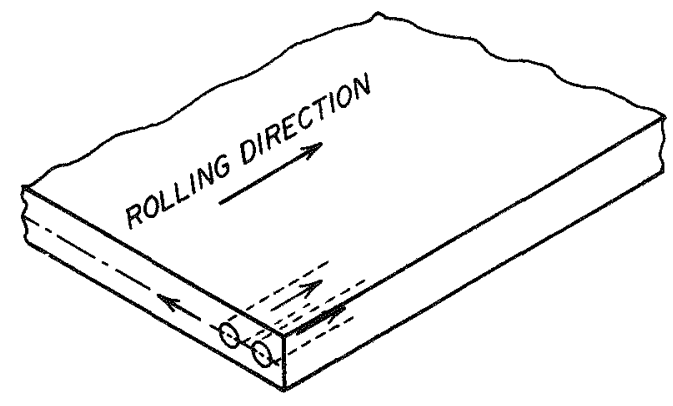

16 AND $25 \mathrm{~mm}$ THICK PLATE

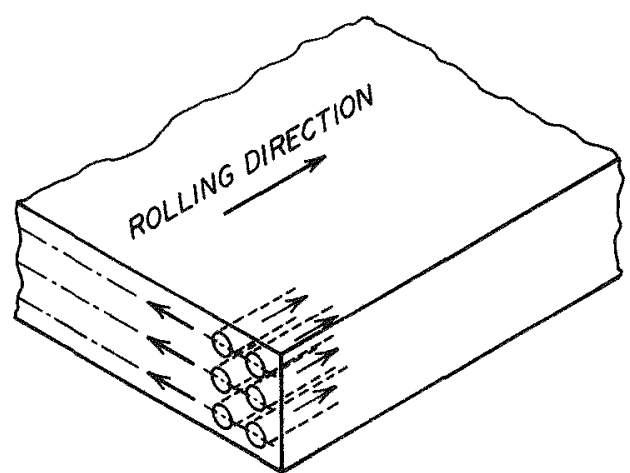

$51 \mathrm{~mm}$ THICK PLATE

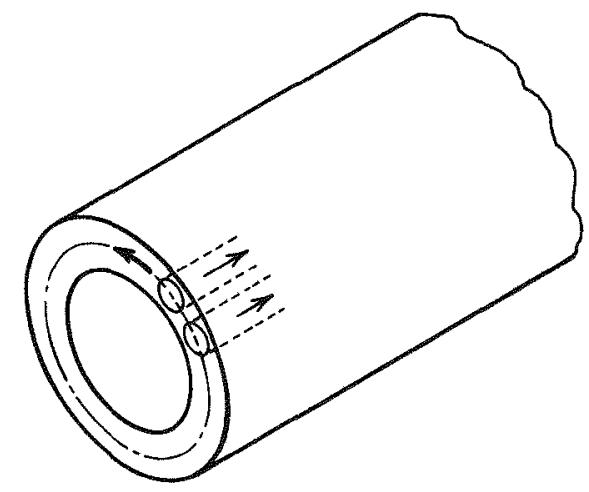

$114,219,406$, AND $711 \mathrm{~mm}$ O.D. PIPE

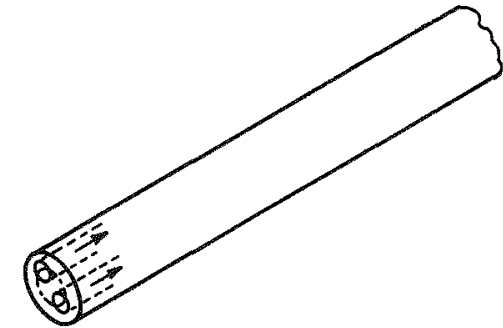

$25 \mathrm{~mm}$ DIA. BAR

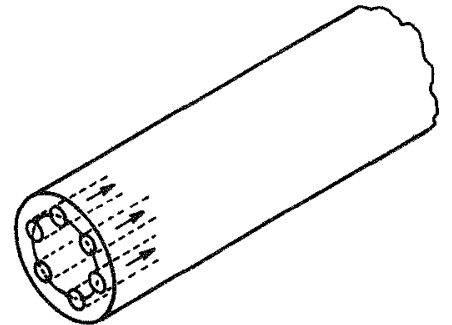

$51 \mathrm{~mm}$ DIA. BAR

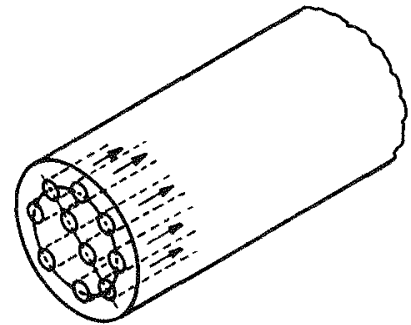

$64 \mathrm{~mm}$ DIA. BAR

Fig. 13. Tensile Test Specimen Cut-Up Diagrams for Various Products of the Reference Heat (8092297) of Type 316 Stainless Steel. 

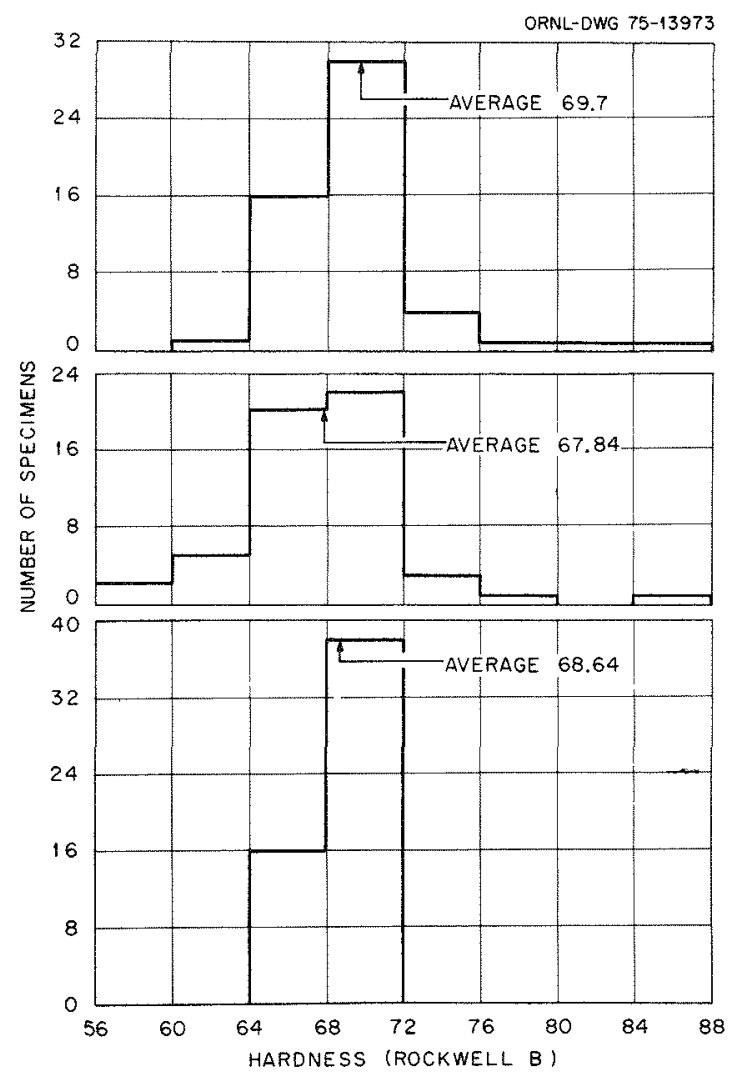

Fig. 14. Hardness Distribution of Specimens Machined from Plate of the Reference Heat of Type 316 Stainless Steel. Left: three different sections of $16-\mathrm{mm}$ (5/8-in.) plate. Below: top, 25-mm (1-in.), and bottom 51-mm (2-in.) plate.

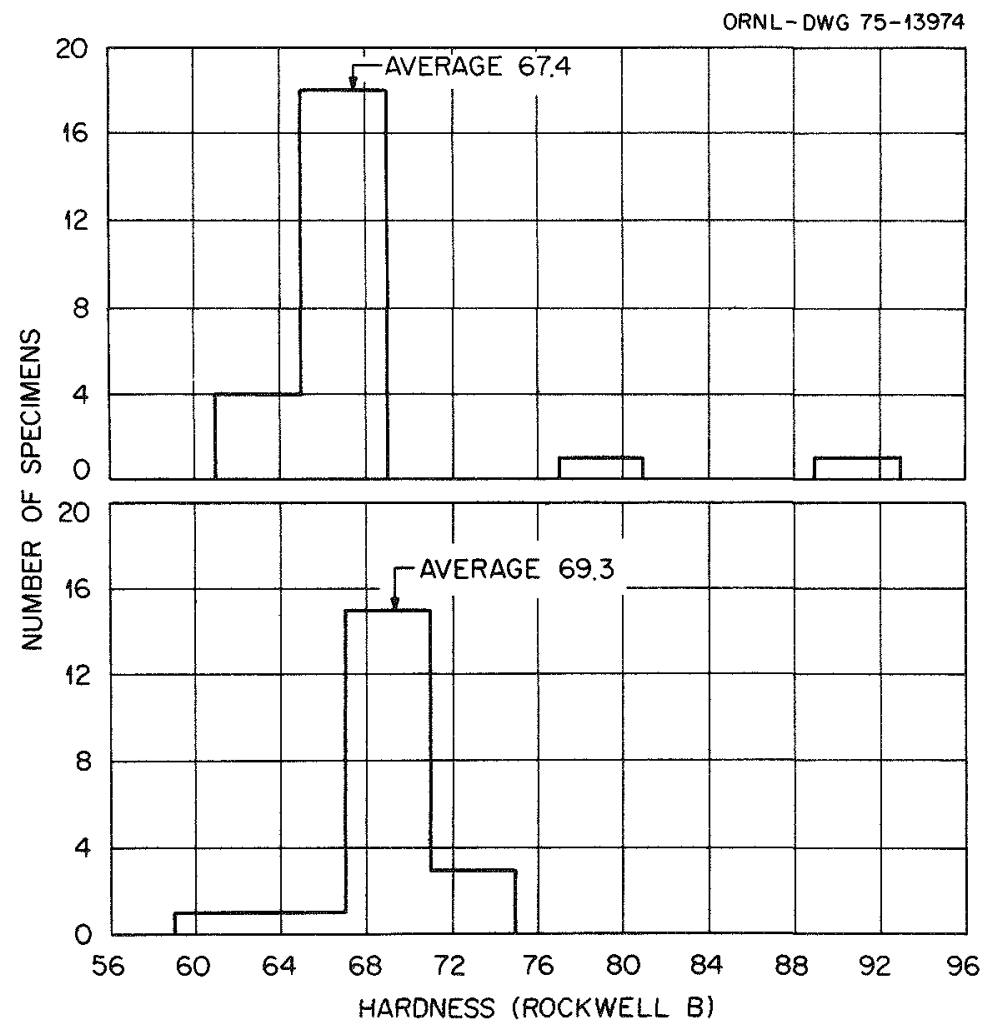




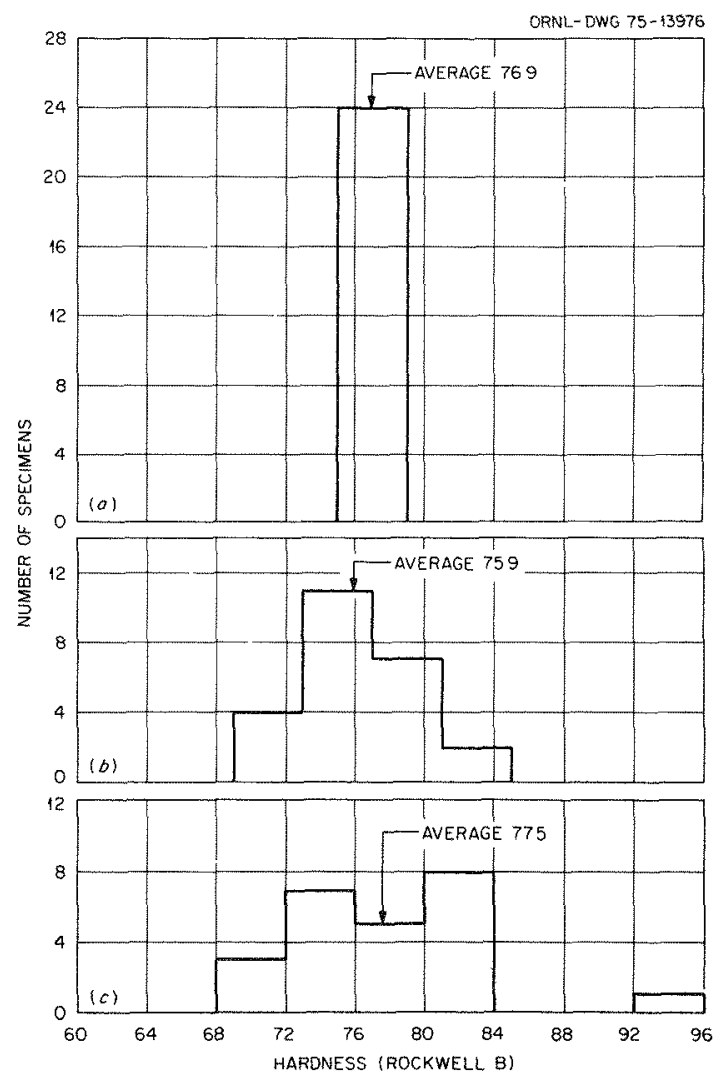

Fig. 15. Hardness Distribution of Specimens Machined from (a) 25-mm- (1-in.-), (b) $51-m m-\left(2-i n_{0}-\right)$, and (c) 64-mm- (2.5-in.-) Diam Bars of the Reference Heat of Type 316 Stainless Steel.
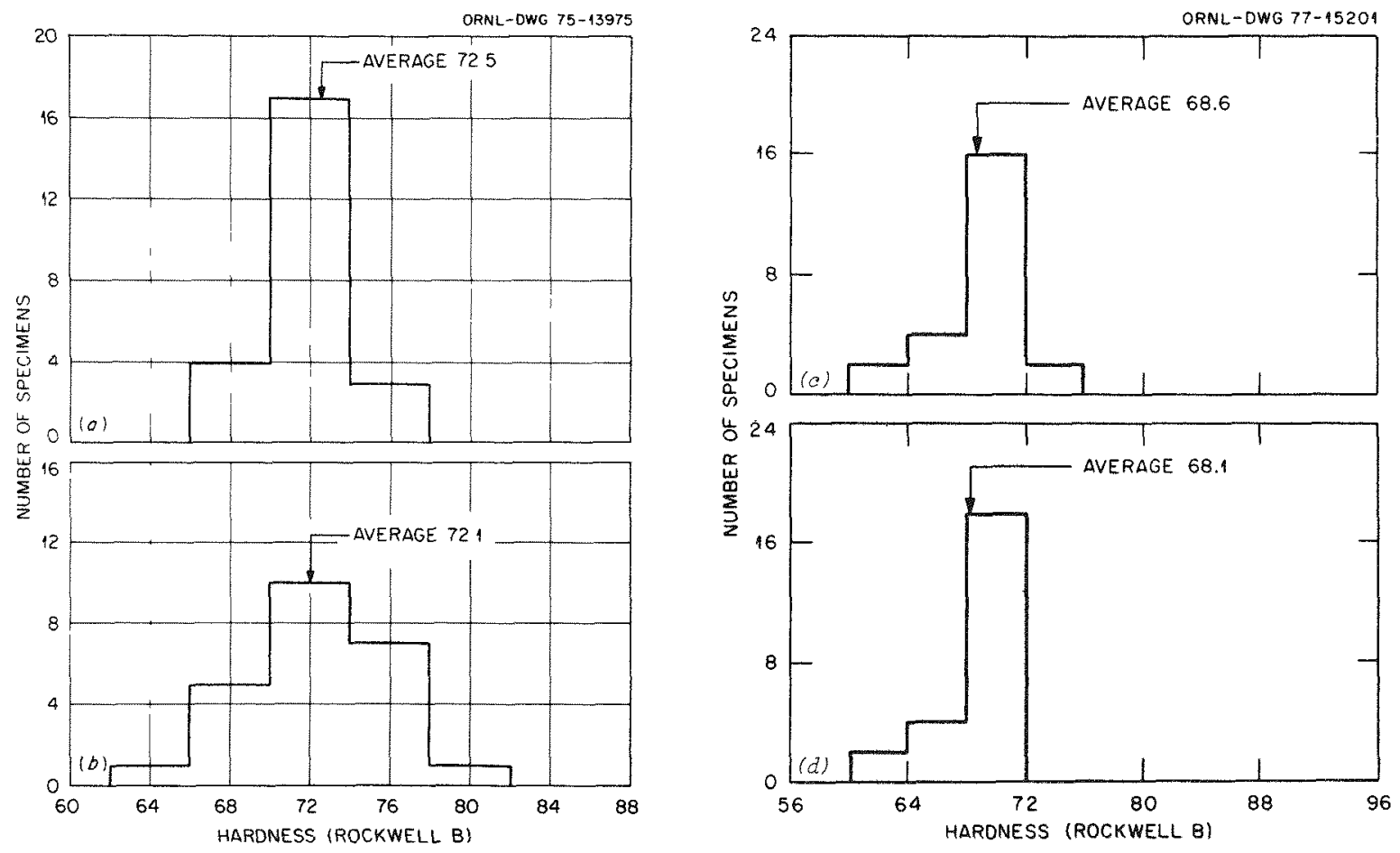

Fig. 16. Hardness Distribution of Specimens Machined from Pipe of the Reference Heat of Type 316 Stainless Steel. (a) $0.114 \mathrm{~m}$ diam (4 1/2 in.). (b) $0.219 \mathrm{~m}$ diam $(85 / 8 \mathrm{in.})$. (c) $0.406 \mathrm{~m} \mathrm{diam} \mathrm{(16} \mathrm{in.)}$ (d) $0.711 \mathrm{~m}$ diam (28 in.). 
Table 4. Summary of Room-Temperature Hardness Values of Various Products of the Reference Heat of Type 316 Stainless Steel

\begin{tabular}{|c|c|c|c|c|c|c|c|c|c|c|c|}
\hline \multirow{3}{*}{$\begin{array}{l}\text { Product } \\
\text { Form }\end{array}$} & \multirow{2}{*}{\multicolumn{3}{|c|}{ Dimensions }} & \multicolumn{4}{|c|}{ As-Received Material } & \multicolumn{4}{|c|}{ Material Reannealed $0.5 \mathrm{hr}$ at $1065^{\circ} \mathrm{C}$} \\
\hline & & & & \multicolumn{3}{|c|}{ Hardness, $\mathrm{R}_{\mathrm{B}}$} & \multirow{2}{*}{$\begin{array}{l}\text { Micro- } \\
\text { hardness } \\
\quad(\mathrm{DPH})\end{array}$} & \multicolumn{3}{|c|}{ Hardness, $R_{B}$} & \multirow{2}{*}{$\begin{array}{l}\text { Micro- } \\
\text { hardness } \\
\text { (DPH) }\end{array}$} \\
\hline & & (11m) & (1110) & Round ${ }^{a}$ & Flat ${ }^{a}$ & F1at ${ }^{b}$ & & Round $^{c}$ & F1at ${ }^{\mathrm{C}}$ & F1at ${ }^{b}$ & \\
\hline Plate & & 16 & $5 / 8$ & 68.7 & 71.8 & $76.6^{\mathrm{d}}$ & & & & $70.5^{\mathrm{e}}$ & \\
\hline Plate & & 25 & 1 & 67.4 & 70.5 & & & 63.2 & 66.2 & & \\
\hline Plate & & 51 & 2 & 69.3 & 72.3 & & & 61.9 & 64.9 & & \\
\hline Bar & & 25 & 1 & 76.9 & 79.8 & 85.5 & 210 & 68.4 & 71.5 & 72.6 & 149 \\
\hline Bar & & 51 & 2 & 75.9 & 78.8 & 79.4 & 176 & 66.2 & 69.3 & 68.0 & 147 \\
\hline Bar & & 64 & $21 / 2$ & 77.5 & 80.3 & 79.9 & 173 & 68.0 & 71.1 & 72.6 & 150 \\
\hline Pipe & $13 \times$ & $\times 114$ OD & $0.5 \times 41 / 2$ & 72.5 & 75.6 & & & 67.6 & 70.7 & & \\
\hline Pipe & $13 \times$ & $\times 219$ OD & $0.5 \times 85 / 8$ & 72.1 & 75.2 & & & 67.4 & 70.5 & & \\
\hline Pipe & $10 \times$ & $\times 406$ OD & $0.4 \times 16$ & 68.6 & 71.7 & & & 63.8 & 66.8 & & \\
\hline Pipe & $10 \times$ & $\times 711 \mathrm{OD}$ & $0.4 \times 28$ & 68.1 & 71.2 & & & 62.7 & 65.7 & & \\
\hline
\end{tabular}

${ }^{a}$ Average of two measurements each on the longitudinal cylindrical surfaces of 24 specimens of each product form (150 specimens of $16-\mathrm{mm}$ plate). Round values are as measured. Flat values have a correction for curvature taken from hardness conversion tables.

Measured on flat surface. Values are averages taken over the diameter of 25-mm bar and radius of $51-$ and 64-mm bar.

${ }^{c}$ Values obtained similarly to the corresponding as-received values, ${ }^{a}$ except that each is the average of four measurements each on five different specimens.

Average of three measurements each on the surface of 18 different blocks cut from the plate.

eAverage of three measurements each on the surface of 12 different blocks cut from the plate. 
1. The most uniform set of specimens, Fig. 15(a), was obtained only from the 25-mm (1-in.) bar product. A11 other products showed variation in hardness among specimens. These variations were most widely spread for plate. The specimens made from the edges of the plates were hardest.

2. For as-received material, all bars showed the higher hardness values than the plate and pipe.

3. The plate and the two 1arge-diameter pipes (406 and $711 \mathrm{~mm}$ diam) showed the lowest values among all as-received product forms. The two small-diameter pipes made by the Mannesman process were harder than the large-diameter pipes made by Rollmet.

4. All product forms decreased in hardness on reannealing for $0.5 \mathrm{hr}$ at $1065^{\circ} \mathrm{C}$. However, the bars, which had highest hardness in the as-received condition, showed the largest drop in both Rockwe11 and microhardness.

5. The plots in Fig. 11 show that reannealing makes the hardness of the bars more uniform.

6. All product forms appear to reach approximately the same hardness values on reannealing.

Tensile Test Procedure

Tensile tests were run on a 44-kN capacity (10,000-1b) Instron universal testing machine at constant crosshead speeds. Strains measured by extensometers and loads from cells in the load train were obtained for the first 0.05 strain, while crosshead displacement versus load was graphed simultaneously and monitored continuously to rupture. The yield strength values were obtained from the extensometer chart (by the $0.2 \%$ offset method), and ultimate tensile strength was obtained from the load-deflection chart. The nominal strain rate of $0.004 / \mathrm{min}$ was obtained by controlling the crosshead movement. However, ASTM testing procedure ${ }^{16}$ requires that the strain rate of the specimens be controlled with a strain pacer. Limited work with a strain pacer, reported in Appendix B, showed that the results obtained by crosshead movement and strain pacer control were not significantly different. During this investigation, the specified strain rate of $0.004 / \mathrm{min}$ was maintained constant throughout the test. 
Tensile Test Matrix

The tensile test matrix for product form characterization was as follows:

1. For each product form and condition, one specimen was tested at a strain rate of $0.004 / \mathrm{min}$ at each test temperature.

2. As-received material was tested at room temperature and 93, 204, $316,427,538$, and $649^{\circ} \mathrm{C}$.

3. Material reannealed $0.5 \mathrm{hr}$ at $1065^{\circ} \mathrm{C}$ was tested at room temperature and $204,427,593$, and $649^{\circ} \mathrm{C}$.

RESULTS AND DISCUSSION

Tensile Properties of As-Received Product Forms

Tensile data on various product forms in the as-received condition are summarized in Tables 5 and 6 . Plots of $0.2 \%$ yield stress, ultimate tensile strength, uniform and total elongation, and reduction of area as functions of test temperature are presented in Figs. 17 through 21. For the sake of clarity, properties for plate and pipe are compared in (a) and for 16-mm plate and bar in (b) of those figures. Nuclear Systems Matemials Handbook ${ }^{14}$ minimum value curves for various properties are also included in these plots.

$0.2 \%$ Yield Strength - All product forms except $10 \times 711-\mathrm{mm}$ pipe met the room-temperature minimum specified value of $207 \mathrm{MPa}$ (30 ksi). Bars of all sizes showed higher yield strength values than plate and pipe. This observation is consistent with previously published results. ${ }^{9}$ As compared with plate and pipe, bar showed more variation in the data, which is expected from hardness gradients observed for bar in Fig. 11. Figure 17 (a) also shows that meeting the room-temperature minimum value does not assure that the elevated-temperature data will lie above the Handbook minimum curve. Such an observation points out that the ratio method of defining minimum value curves may not be adequate for elevatedtemperature applications. 
Table 5. Tensile Properties of 16-mm (5/8-in.) Plate of Reference Heat 8092297 of Type 316 Stainless Steel, Tested in Mill-Annealed (As-Received) Condition at a Strain Rate of $0.004 / \mathrm{min}$

\begin{tabular}{|c|c|c|c|c|c|c|c|c|c|c|c|c|c|}
\hline \multirow{3}{*}{ Test } & \multirow{2}{*}{\multicolumn{2}{|c|}{$\begin{array}{c}\text { Test } \\
\text { Temperature }\end{array}$}} & \multicolumn{5}{|c|}{ Stress, MPa (ksi) } & \multicolumn{3}{|c|}{ Elongation, \% } & \multirow{3}{*}{$\begin{array}{c}\text { Reduction } \\
\text { of } \\
\text { Area } \\
(\%)\end{array}$} & \multicolumn{2}{|c|}{$\begin{array}{l}\text { Work to Plastic } \\
\text { Instability }\end{array}$} \\
\hline & & & \multirow{2}{*}{$\begin{array}{l}\text { Proportional } \\
\text { Limit }\end{array}$} & \multicolumn{3}{|c|}{ Yield } & \multirow{2}{*}{ Tensile } & \multirow{2}{*}{ Uniform } & \multicolumn{2}{|c|}{ Tota1 } & & & \\
\hline & $\left({ }^{\circ} \mathrm{C}\right)$ & $\left({ }^{\circ} \mathrm{F}\right)$ & & $0.02 \%$ & & $0.2 \%$ & & & 1 in. & $2 \mathrm{in.}$ & & $\left(\frac{\mathrm{MJ}}{\mathrm{m}^{3}}\right)$ & $\left(\frac{\mathrm{ft}-1 \mathrm{~b}}{\mathrm{in} \cdot{ }^{3}}\right)$ \\
\hline 15539 & 25 & 77 & $115(16.7)$ & $194(28.1)$ & 227 & $(33.0)$ & $583(84.5)$ & 60.1 & & $73.9^{\mathrm{a}}$ & 79.6 & 313 & 3787 \\
\hline 15540 & 93 & 200 & $76(11.0)$ & $150(21.8)$ & 191 & $(27.7)$ & $513(74.4)$ & 39.5 & & $51.6^{\mathrm{a}}$ & 77.2 & 177 & 2123 \\
\hline 15541 & 204 & 400 & $70(10.2)$ & $125(18.2)$ & 155 & $(22.5)$ & $493(71.5)$ & 38.8 & & $44.7^{\mathrm{b}}$ & 73.5 & 162 & 1953 \\
\hline 15543 & 371 & 700 & $68(9.9)$ & $111(16.1)$ & 142 & $(20.6)$ & $513(74.4)$ & 37.7 & & $46.0^{\mathrm{a}}$ & 67.0 & 157 & 1900 \\
\hline 15544 & 427 & 800 & $62(9.0)$ & $102(14.7)$ & 137 & $(19.9)$ & $504(73.1)$ & 39.9 & & $46.4^{\mathrm{a}}$ & 68.0 & 166 & 2003 \\
\hline 15545 & 482 & 900 & $62(9.0)$ & $101(14.6)$ & 127 & $(18.4)$ & $505(73.2)$ & 44.3 & & $48.3^{\mathrm{b}}$ & 66.4 & 181 & 2188 \\
\hline 15546 & 538 & 1000 & $73(10.6)$ & $104(15.1)$ & 125 & $(18.1)$ & $478(69.3)$ & 38.6 & 54.9 & $47.1^{\mathrm{a}}$ & 67.4 & 150 & 1810 \\
\hline 15547 & 593 & 1100 & $67(9.8)$ & $101(14.7)$ & 120 & $(17.4)$ & $425(61.6)$ & 40.2 & 61.0 & $51.6^{\mathrm{a}}$ & 67.5 & 140 & 1695 \\
\hline 15548 & 649 & 1200 & $63(9.2)$ & $95(13.8)$ & 117 & $(16.9)$ & $316(45.8)$ & 27.0 & 51.7 & $54.4^{b}$ & 48.7 & 78 & 938 \\
\hline 15550 & 760 & 1400 & $70(10.2)$ & $90(13.0)$ & 105 & $(15.3)$ & $174(25.3)$ & 9.9 & 55.4 & $55.9^{\mathrm{b}}$ & 70.6 & 17 & 204 \\
\hline
\end{tabular}

${ }^{a}$ Specimen broke at center and thus contained the neck.

${ }^{b}$ Specimen broke off-center and therefore did not contain the neck. 
Table 6. Tensile Properties of Various Product Forms of the Reference Heat (8092297) of Type 316 Stainless Steel Tested at a Strain Rate of $0.004 / \mathrm{min}$

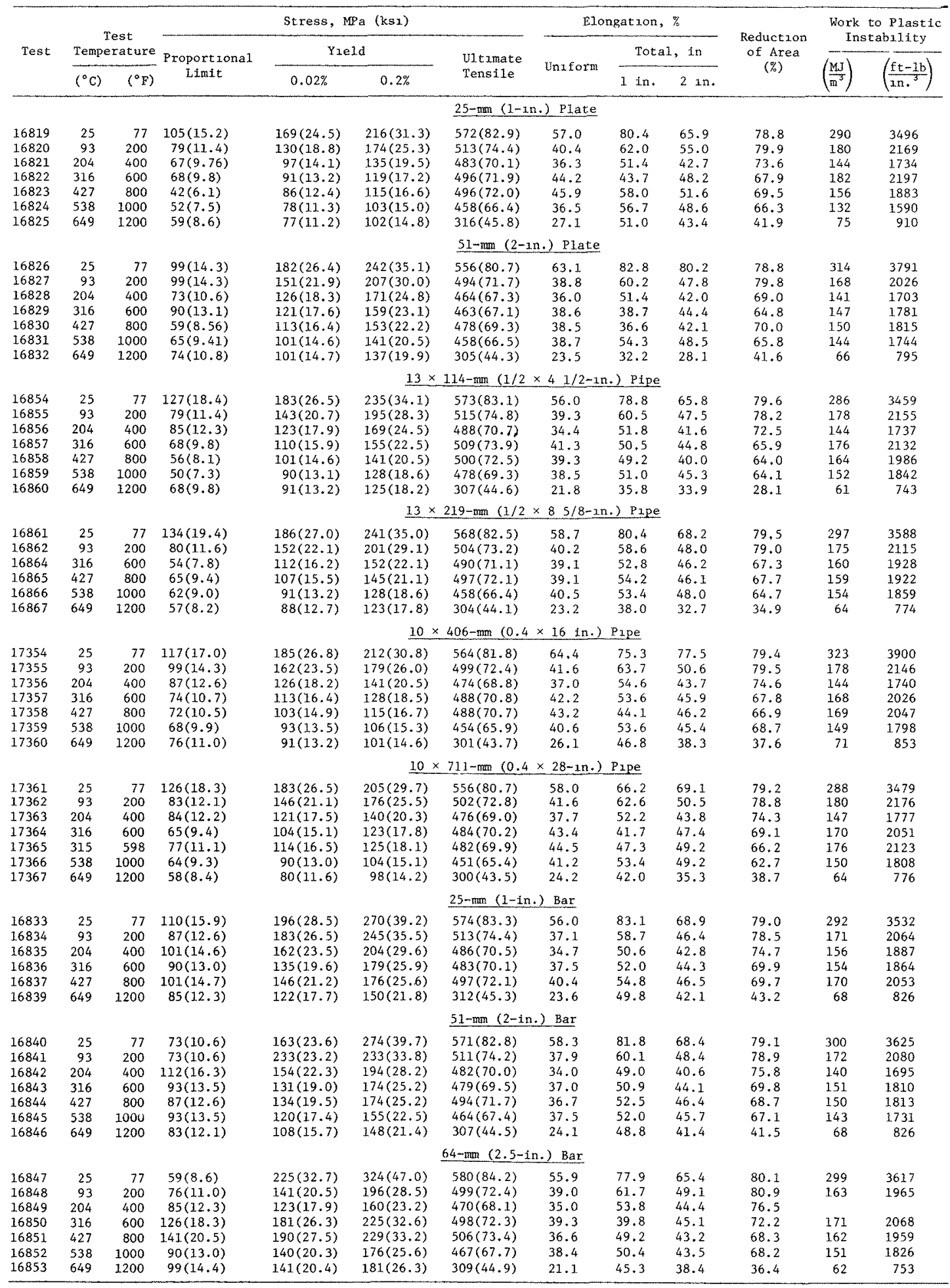



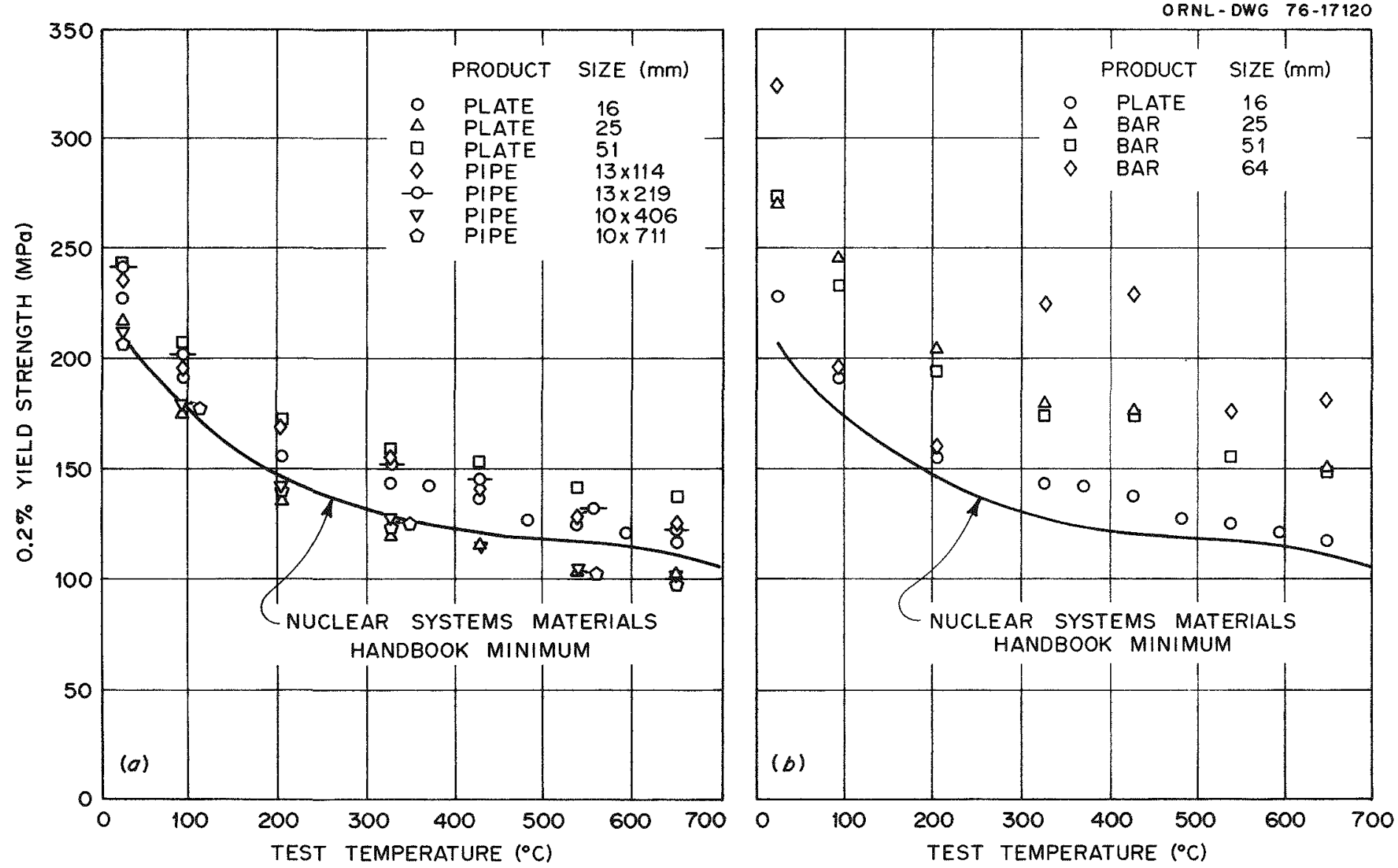

Fig. 17. The $0.2 \%$ Yield Strength as a Function of Test Temperature for Various Products of the Reference Heat (8092297) of Type 316 Stainless Steel in the As-Received Condition at a Strain Rate of $0.004 / \mathrm{min}$. (a) Plate and pipe. (b) $16-\mathrm{mm}$ plate and bar. 

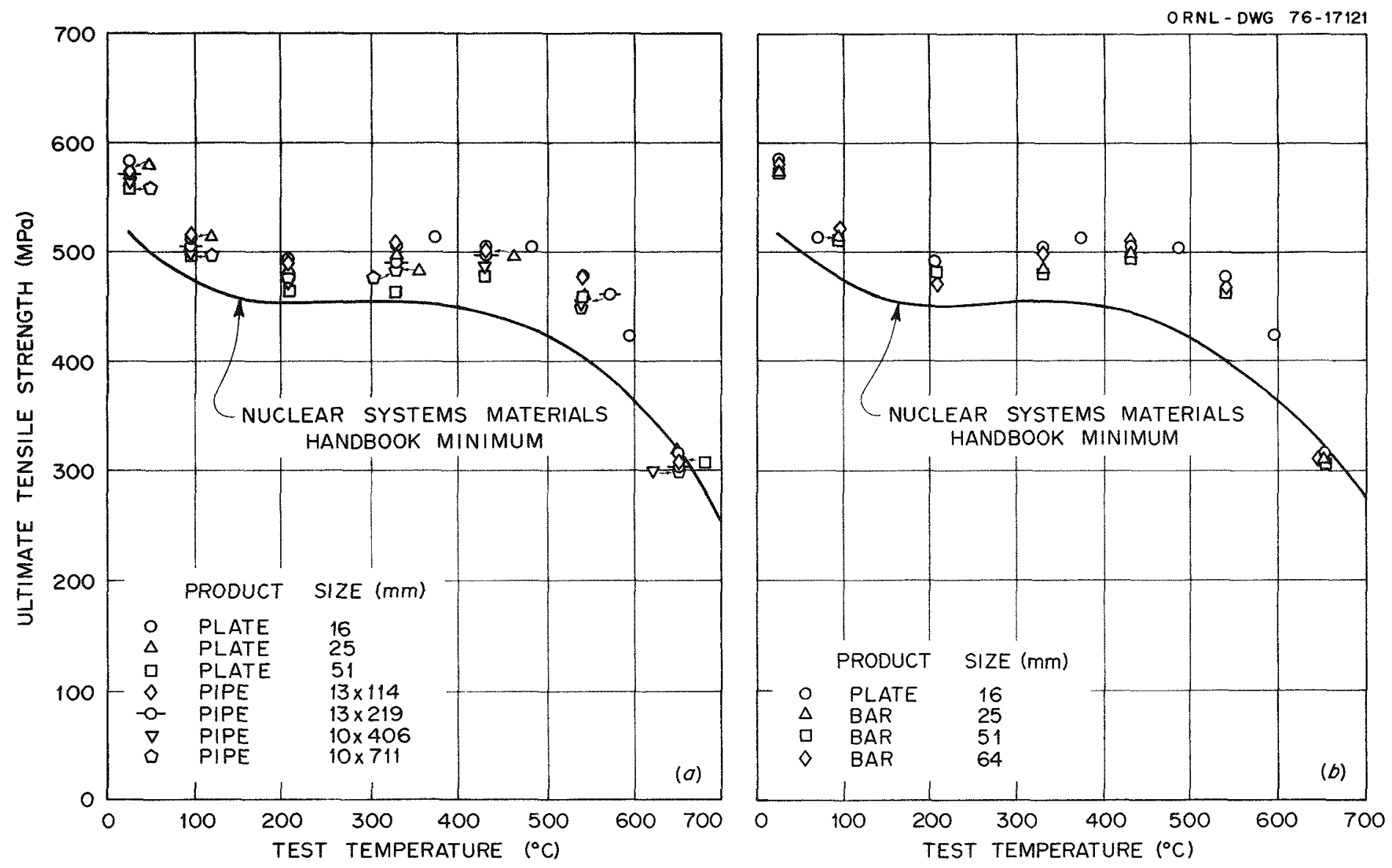

Fig. 18. The U1timate Tensile Strength as a Function of Test Temperature for Various Products of the Reference Heat (8092297) of Type 316 Stainless Steel in the As-Received Condition at a Strain Rate of $0.004 / \mathrm{min}$. (a) Plate and pipe. (b) $16-\mathrm{mm}$ plate and bar. 

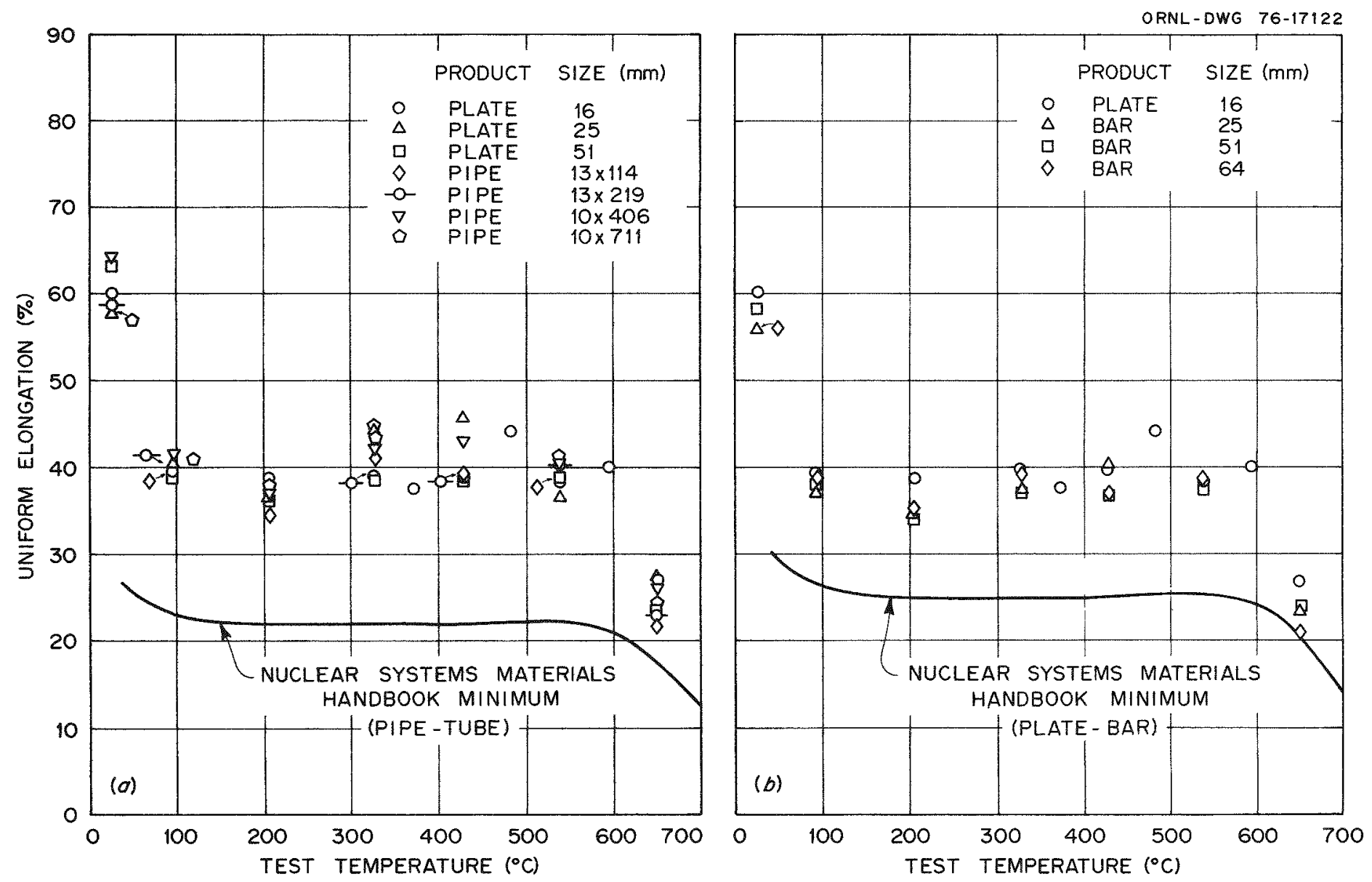

Fig. 19. The Uniform Elongation as a Function of Test Temperature for Various Products of the Reference Heat (8092297) of Type 316 Stainless Steel in the As-Received Condition at a Strain Rate of $0.004 / \mathrm{min}$. (a) Plate and pipe. (b) 16-mm plate and bar. 

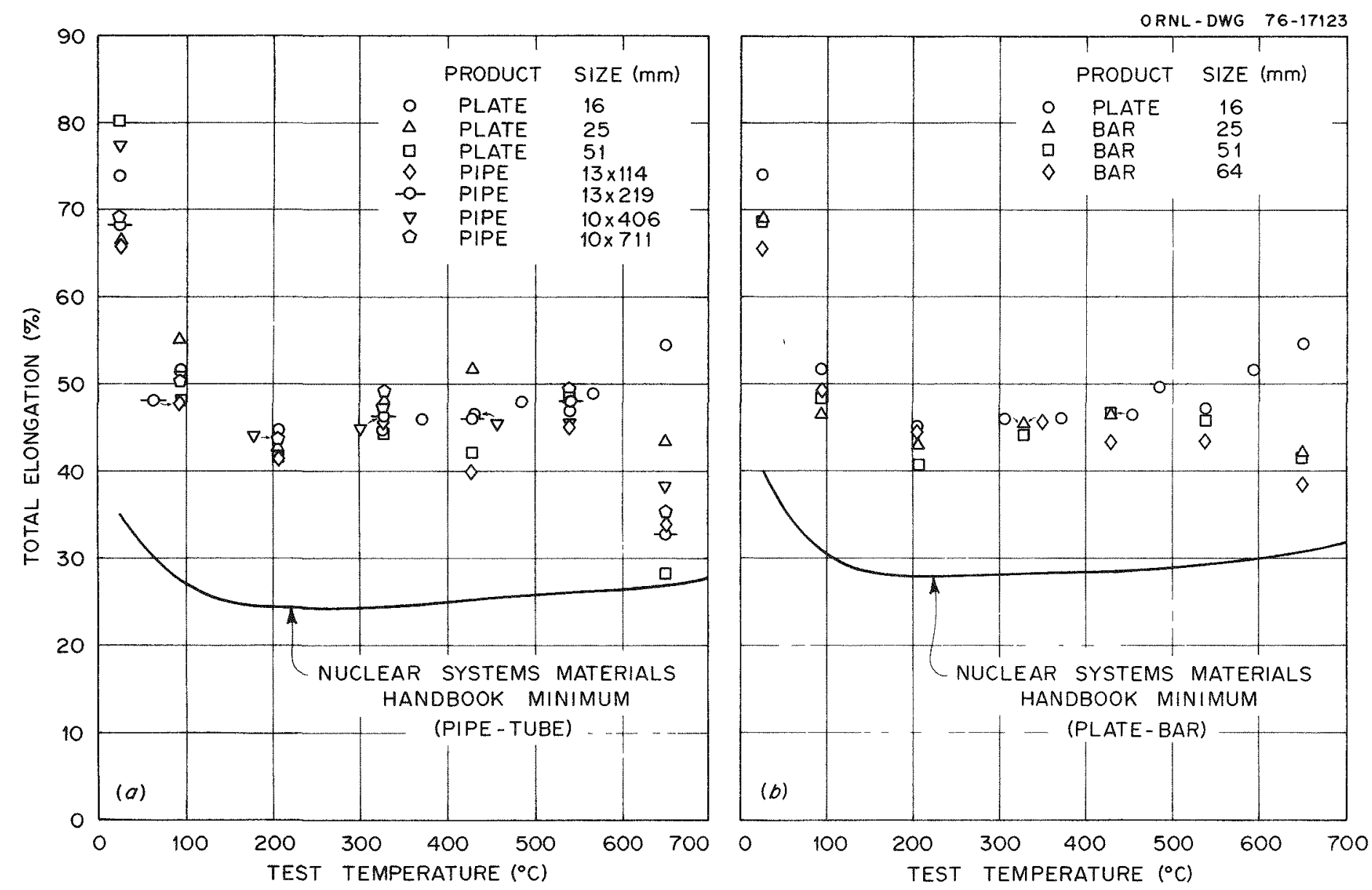

Fig. 20. The Total Elongation as a Function of Test Temperature for Various Products of the Reference Heat (8092297) of Type 316 Stainless Steel in the As-Received Condition at a Strain Rate of $0.004 / \mathrm{min}$. (a) Plate and pipe. (b) 16-mm plate and bar. 

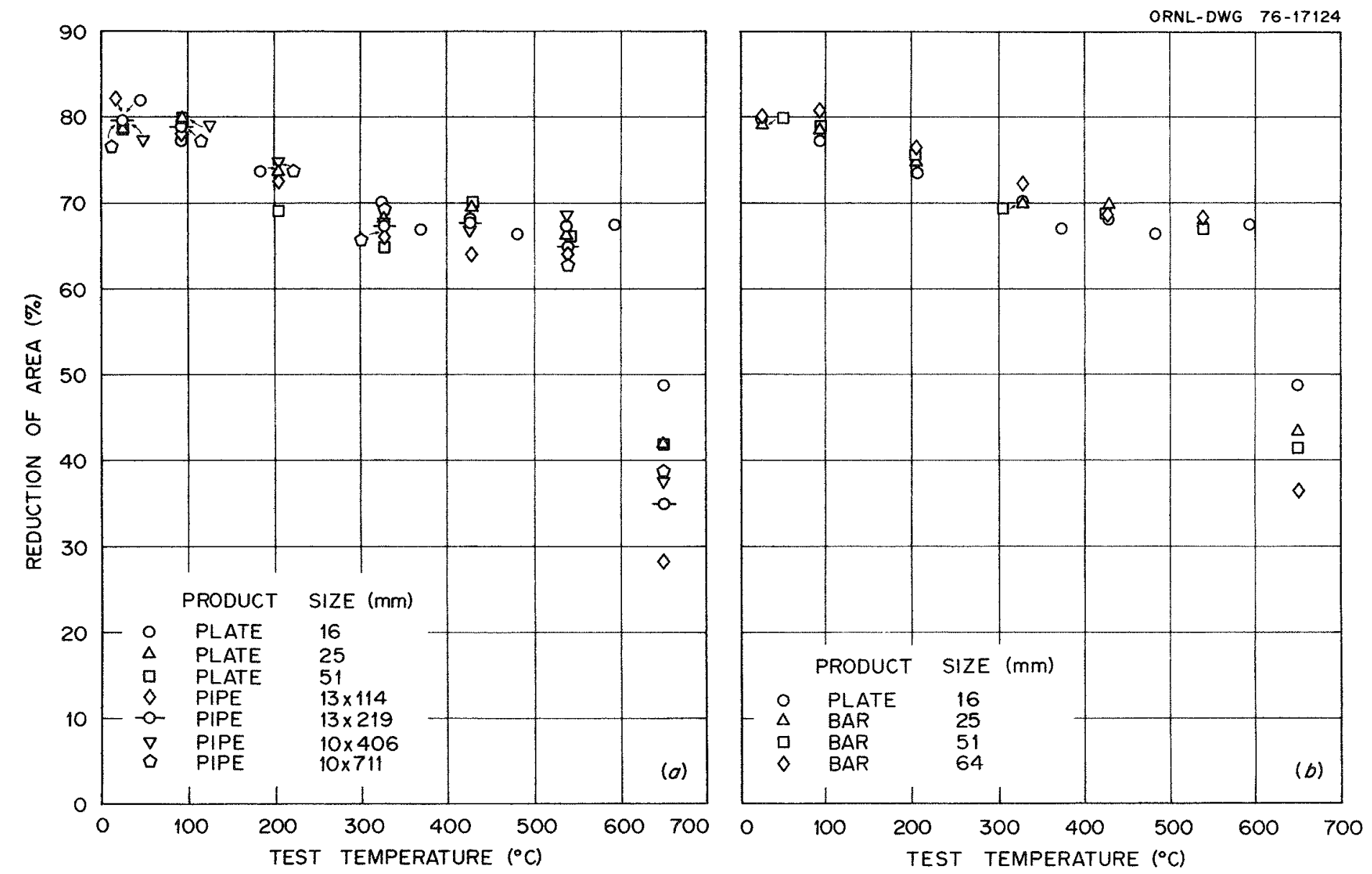

Fig. 21. The Reduction of Area as a Function of Test Temperature for Various Products of the Reference Heat (8092297) of Type 316 Stainless Steel in the As-Received Condition at a Strain Rate of $0.004 / \mathrm{min}$. (a) Plate and pipe. (b) 16-mm plate and bar. 
U1timate Tensile Strength - Room-temperature ultimate tensile strength values for all product forms were above the minimum specified value of $517 \mathrm{MPa}$ (75 ksi). Unlike yield strength data, there was no significant difference between the ultimate tensile strength data on various product forms for the whole temperature range. Ultimate tensile strength for all product forms was above the Handbook minimum curve for all test temperatures except $649^{\circ} \mathrm{C}\left(1200^{\circ} \mathrm{F}\right)$. Strain-rate sensitivity of ultimate tensile strength at $649^{\circ} \mathrm{C}$ is the possible reason for the observed values to fall below the minimum curve. Ultimate tensile strength values for all products showed a slight increase in the temperature range from 300 to $500^{\circ} \mathrm{C}\left(570-930^{\circ} \mathrm{F}\right)$, and this is associated with possible dynamic strainaging effects.

Uniform Elongation - Uniform elongation data for all product forms were above the Handbook minimum for the whole temperature range of this investigation. Dynamic strain aging over the range 300 to $500^{\circ} \mathrm{C}$ resulted in increased values of uniform elongation for all product forms. The Handbook includes one minimum value curve for pipe and tube and another for plate and bar. The present data on various products show no real differences in values for the different products, but if a separation is desired the plate should be combined with pipe and tube rather than with bar. Furthermore, the minimum value curve should be higher for plate, pipe, and tube than for bar, which is contrary to the values reported in the Handbook.

Total Elongation - Total elongation values for all product forms were above the Handbook minimum curves. The comments made for uniform elongation on separate minimum curves for plate, pipe, tube, and bar also hold true for total elongation.

One feature missing from the Handbook minimum value curves is the experimentally observed sharp drop in total elongation at $649^{\circ} \mathrm{C}\left(1200^{\circ} \mathrm{F}\right)$. Such a drop is associated with tensile ductility minimum conditions, which are discussed elsewhere. ${ }^{17}$

Reduction of Area - Reduction of area values for various product forms are plotted in Fig. 21. The Handbook does not contain any minimum value curve for this property. However, it is interesting to note that 
reductions of area for all product forms were essentially the same, and all showed a sharp drop at $649^{\circ} \mathrm{C}$. Such a drop is again associated with the ductility minimum conditions, which are discussed elsewhere. ${ }^{17}$

Work to Plastic Instability - The area under the stress-strain curve up to the ultimate tensile strength point is a measure of toughness of the material. Values of this quantity were computed for various product forms of the reference heat and are displayed as a function of test temperature in Fig. 22. These plots show that the toughness of a11 products decreases sharply at a test temperature of $649^{\circ} \mathrm{C}$. This is the same temperature at which creep effects become important and fracture becomes intergranular. ${ }^{17}$ The dynamic strain-aging effects were also reflected in toughness values.
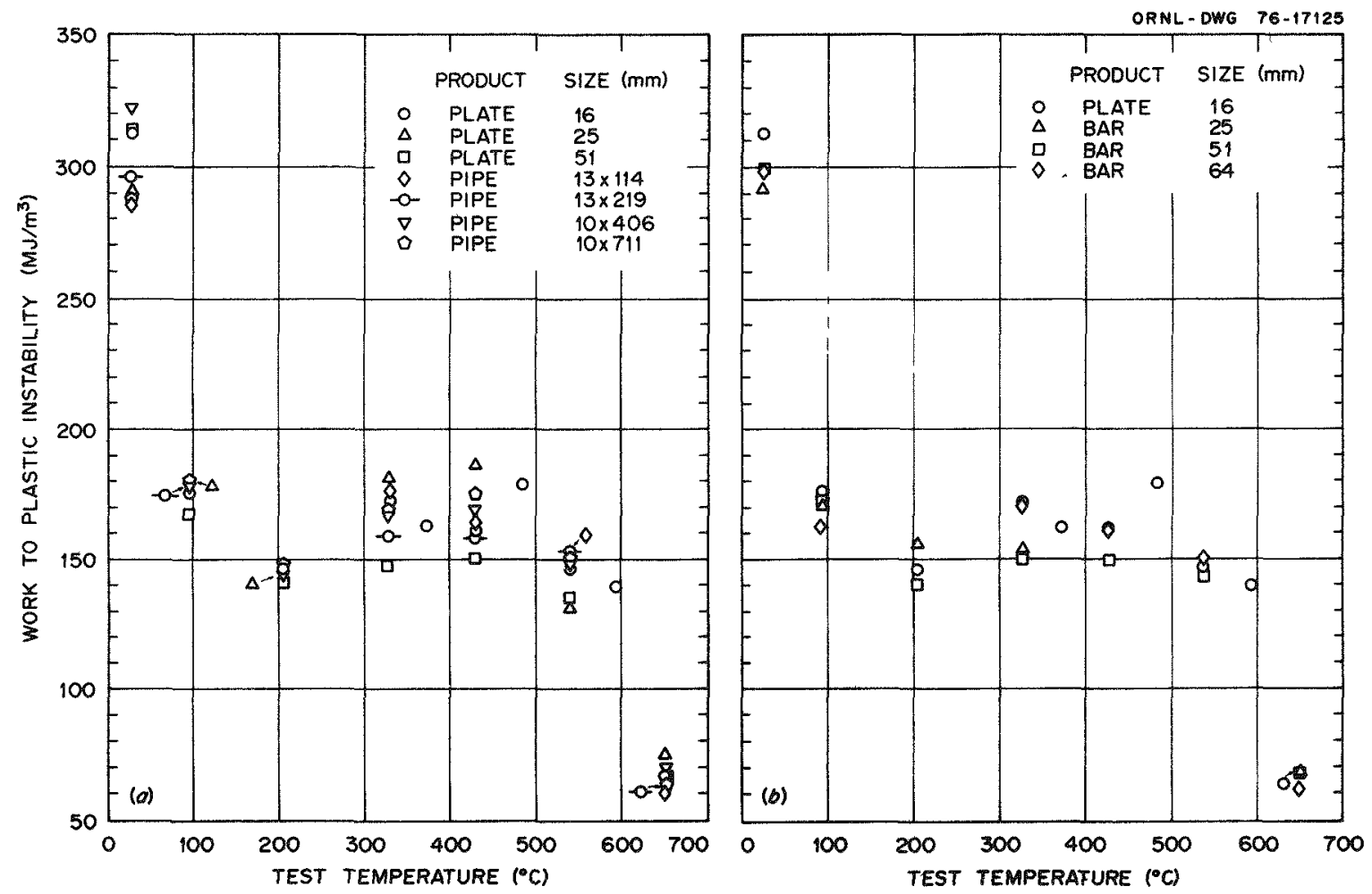

Fig. 22. Work to Plastic Instability as a Fucntion of Test Temperature for Various Products of the Reference Heat (8092297) of Type 316 Stainless Steel in the As-Received Condition at a Strain Rate of $0.004 / \mathrm{min}$. (a) Plate and pipe. (b) 16-mm plate and bar. 
Tensile Properties of Reannealed Product Forms

Tensile data on various products in the reannealed condition are summarized in Tables 7 and 8 . Test temperature variation of $0.2 \%$ yield strength, ultimate tensile strength, uniform and total elongation, and reduction of area are plotted in Figs. 23 through 27 . For the sake of clarity, properties for plate and pipe are compared in (a) and for 16-mm plate and bar in (b) of those figures. Nuclear Systems Materials Handbook ${ }^{14}$ minimum value curves for various properties are also included in the plots.

Yield Strength - Reannealing lowered the $0.2 \%$ yield strength of all products. Some plate and pipe products met the room-temperature minimum specified value of $207 \mathrm{MPa}(30.0 \mathrm{ksi})$. However, all plate and pipe products showed yield strength values below the Handbook minimum at elevated temperatures. Bars of all sizes met the room-temperature minimum specified value of $207 \mathrm{MPa}(30.0 \mathrm{ksi})$. Bars of $16-$ and $64-\mathrm{mm}$ (5/8- and 2.5-in.) diameter had elevated-temperature yield strength values above the Handbook minimum curve. Elevated-temperature yield strength values for 51-mm-diam (2-in.) bar were below the Handbook minimum curve. Figure 23 shows that reannealing lowers the yield strength of all products. This observation is consistent with the previously published results ${ }^{9}, 10$ on types 304 and 316 stainless steel. This figure also shows that meeting the room-temperature minimum value does not assure that elevated-temperature data will lie above the Handbook minimum curve. Such an observation points out that the ratio method of defining minimum value curves may not be adequate for elevatedtemperature applications. Results presented above and earlier ${ }^{9}, 10$ also suggest that the room-temperature minimum specified value of types 304 and 316 stainless steel should be less than $207 \mathrm{MPa}$ (30 ksi) for the reannealed condition.

U1timate Tensile Strength - Room-temperature ultimate tensile strength values for all product forms in the reannealed condition were above the minimum specified value of $517 \mathrm{MPa}(75.0 \mathrm{ksi})$. Unlike yield strength data, the ultimate tensile strength data on various products did not differ significantly for the whole temperature range. U1timate 
Table 7. Tensile Properties of 16-mm (5/8-in.) Plate ${ }^{a}$ of the Reference Heat of Type 316 Stainless Stee1, Tested at a Strain Rate of $0.004 / \mathrm{min}$

\begin{tabular}{|c|c|c|c|c|c|c|c|c|c|c|c|c|}
\hline \multirow{3}{*}{ Test } & \multirow{2}{*}{\multicolumn{2}{|c|}{$\begin{array}{c}\text { Test } \\
\text { Temperature }\end{array}$}} & \multicolumn{4}{|c|}{ Stress, MPa (ksi) } & \multicolumn{3}{|c|}{ Elongation, \% } & \multirow{3}{*}{$\begin{array}{c}\text { Reduction } \\
\text { of } \\
\text { Area } \\
(\%)\end{array}$} & \multicolumn{2}{|c|}{$\begin{array}{l}\text { Work to Plastic } \\
\text { Instability }\end{array}$} \\
\hline & & & \multirow{2}{*}{$\begin{array}{l}\text { Proportiona } 1 \\
\text { Limit }\end{array}$} & \multicolumn{2}{|c|}{ Yield } & \multirow{2}{*}{ Tensile } & \multirow{2}{*}{ Uniform } & \multicolumn{2}{|c|}{ Tota1 } & & & \\
\hline & $\left({ }^{\circ} \mathrm{C}\right)$ & $\left({ }^{\circ} \mathrm{F}\right)$ & & $0.02 \%$ & $0.2 \%$ & & & 1 in. & $2 \mathrm{in.}$ & & $\left(\frac{\mathrm{MJ}}{\mathrm{m}^{3}}\right)$ & $\left(\frac{\mathrm{ft}-\mathrm{Ib}}{\mathrm{in} \cdot{ }^{3}}\right)$ \\
\hline 15452 & 25 & 77 & $168(24.4)$ & $198(28.7)$ & $211(30.6)$ & $571(82.8)$ & 62.0 & $83.9^{\mathrm{b}}$ & 69.8 & 78.8 & 314 & 3798 \\
\hline 15453 & 93 & 200 & $119(17.2)$ & $161(23.4)$ & $179(25.9)$ & $514(74.6)$ & 40.3 & $61.8^{b}$ & 49.4 & 76.9 & 177 & 2134 \\
\hline 15454 & 204 & 400 & $107(15.5)$ & $133(19.3)$ & $144(20.9)$ & $490(71.1)$ & 36.7 & $51.4^{\mathrm{b}}$ & 43.5 & 76.4 & 147 & 1771 \\
\hline 15456 & 371 & 700 & $96(13.9)$ & $106(15.4)$ & $117(17.0)$ & $499(72.4)$ & 40.8 & $39.9^{c}$ & 44.9 & 71.8 & 163 & 1965 \\
\hline 15457 & 427 & 800 & $77(11.1)$ & $105(15.2)$ & $117(16.9)$ & $502(72.8)$ & 40.7 & $39.6^{\mathrm{c}}$ & 44.7 & 69.8 & 161 & 1948 \\
\hline 15458 & 482 & 900 & $77(11.2)$ & $99(14.3)$ & $106(15.4)$ & $488(70.8)$ & 45.3 & $57.0^{\mathrm{b}}$ & 50.0 & 70.8 & 179 & 2164 \\
\hline 15459 & 538 & 1000 & $79(11.4)$ & $92(13.4)$ & $105(15.2)$ & $464(67.3)$ & 39.2 & $57.0^{\mathrm{b}}$ & 47.7 & 65.4 & 147 & 1782 \\
\hline 16089 & 565 & 1050 & $65(9.4)$ & $96(13.9)$ & $99(14.4)$ & $432(62.7)$ & 43.5 & d & 49.1 & 69.7 & 153 & 1850 \\
\hline 15595 & 593 & 1100 & $88 \quad(12.8)$ & $99(14.3)$ & $110(16.0)$ & $413(59.9)$ & 41.7 & $50.4^{\mathrm{c}}$ & 52.7 & 64.9 & 143 & 1724 \\
\hline 16086 & 704 & 1300 & $63(9.2)$ & $85(12.4)$ & $95(13.7)$ & $228(33.0)$ & 20.2 & $d$ & 51.1 & 47.9 & 42 & 506 \\
\hline 16087 & 732 & 1350 & $60(8.8)$ & $82(11.9)$ & $92(13.4)$ & $198(28.7)$ & 14.2 & $\mathrm{~d}$ & 61.9 & 50.5 & 27 & 332 \\
\hline 16088 & 760 & 1400 & $57(8.3)$ & $79(11.5)$ & $90(13.0)$ & $170(24.7)$ & 10.1 & $\mathrm{~d}$ & 70.3 & 60.6 & 17 & 200 \\
\hline
\end{tabular}

${ }^{a}$ Reannealed for $0.5 \mathrm{hr}$ at $1065^{\circ} \mathrm{C}\left(1950^{\circ} \mathrm{F}\right)$.

${ }^{\mathrm{b}}$ Contains the necked region.

${ }^{\mathrm{c}}$ Specimen broke off-center and therefore did not contain the neck.

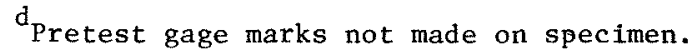


Table 8. Tensile Properties of Various Reannealed Product Forms of the Reference Heat (8092297) of Type 316 Stainless Stee1 Tested at a Strain Rate of $0.004 / \mathrm{min}$

\begin{tabular}{|c|c|c|c|c|c|c|c|c|c|c|c|c|}
\hline \multirow{3}{*}{ Test } & \multirow{2}{*}{\multicolumn{2}{|c|}{$\begin{array}{c}\text { Test } \\
\text { Temperature }\end{array}$}} & \multicolumn{4}{|c|}{ Stress, MPa (ksi) } & \multicolumn{3}{|c|}{ Elongation, \% } & \multirow{3}{*}{$\begin{array}{c}\text { Reduction } \\
\text { of Area } \\
(\%)\end{array}$} & \multirow{2}{*}{\multicolumn{2}{|c|}{$\begin{array}{c}\text { Work to Plastic } \\
\text { Instability }\end{array}$}} \\
\hline & & & \multirow{2}{*}{$\begin{array}{c}\text { Proportional } \\
\text { Linft }\end{array}$} & \multicolumn{2}{|c|}{ Yield } & \multirow{2}{*}{$\begin{array}{l}\text { U1timate } \\
\text { Tensile }\end{array}$} & \multirow{2}{*}{ Uniform } & \multicolumn{2}{|c|}{ Total, in } & & & \\
\hline & $\left({ }^{\circ} \mathrm{C}\right)$ & $\left({ }^{\circ} \mathrm{F}\right)$ & & $0.02 \%$ & $0.2 \%$ & & & 1 in. & 2 in. & & $\left(\frac{\mathrm{MJ}}{\mathrm{m}^{3}}\right)$ & $\left(\frac{f t-1 b}{\ln \cdot^{3}}\right)$ \\
\hline \multicolumn{13}{|c|}{ 25-mm (1-in.) P1ate } \\
\hline 17612 & 25 & 77 & $126(18.3)$ & $188(27.3)$ & $205(29.7)$ & $568(82.3)$ & 66.22 & 82.90 & 70.23 & 77.61 & 333 & 4023 \\
\hline 17613 & 204 & 400 & $98(14.2)$ & $123(17.8)$ & $130(18.8)$ & $468(67.9)$ & 37.77 & 53.10 & 43.00 & 74.22 & 1.44 & 1741 \\
\hline 17614 & 427 & 800 & $53(7.7)$ & $88(12.8)$ & $106(15.3)$ & $492(71.4)$ & 38.17 & 59.25 & 51.75 & 69.77 & 144 & 1744 \\
\hline $17615^{a}$ & 593 & 1100 & $61(8.8)$ & $83(12.0)$ & $92(13.3)$ & $397(57.5)$ & 44.06 & 48.20 & 58.03 & 60.52 & 147 & 1772 \\
\hline 17616 & 649 & 1200 & $61(8.8)$ & $84(12.2)$ & $90(13.1)$ & $303(44.0)$ & 29.97 & 42.65 & 38.04 & 38.36 & 80 & 972 \\
\hline \multicolumn{13}{|c|}{ 51-mn (2-in.) Plate } \\
\hline $\begin{array}{l}17617 \\
17618 \\
17619 \\
17620 \\
17621\end{array}$ & $\begin{array}{r}25 \\
204 \\
427 \\
593 \\
649\end{array}$ & $\begin{array}{r}77 \\
400 \\
800 \\
1100 \\
1200\end{array}$ & $\begin{array}{r}116(16.8) \\
57(8.2) \\
46(6.6) \\
46(6.7) \\
62(9.0)\end{array}$ & $\begin{array}{r}170(24.7) \\
104(15.1) \\
86(12.5) \\
77(11.2) \\
79(11.4)\end{array}$ & $\begin{array}{r}198(28.7) \\
124(18.0) \\
102(1.4 .8) \\
88(12.7) \\
88(12.7)\end{array}$ & $\begin{array}{l}543(78.7) \\
443(64.3) \\
460(66.7) \\
374(54.2) \\
297(43.1)\end{array}$ & $\begin{array}{l}65.58 \\
40.17 \\
44.27 \\
43.73 \\
31.50\end{array}$ & $\begin{array}{l}84.45 \\
52.30 \\
54.20 \\
57.92 \\
45.15\end{array}$ & $\begin{array}{l}72.93 \\
43.80 \\
47.05 \\
49.25 \\
37.43\end{array}$ & $\begin{array}{l}79.36 \\
70.58 \\
64.22 \\
57.94 \\
41.28\end{array}$ & $\begin{array}{r}309 \\
139 \\
158 \\
133 \\
81\end{array}$ & $\begin{array}{r}3735 \\
1674 \\
1907 \\
1601 \\
976\end{array}$ \\
\hline \multicolumn{13}{|c|}{$13 \times 114-\mathrm{mm}(1 / 2 \times 41 / 2-1 \mathrm{n}$.$) Pipe$} \\
\hline $\begin{array}{l}17637 \\
17638 \\
17639 \\
17640 \\
17641\end{array}$ & $\begin{array}{r}25 \\
204 \\
427 \\
593 \\
649\end{array}$ & $\begin{array}{r}77 \\
400 \\
800 \\
1100 \\
1200\end{array}$ & $\begin{array}{r}144(20.9) \\
99(14.3) \\
87(12.6) \\
62(9.0) \\
66(9.6)\end{array}$ & $\begin{array}{r}199(28.9) \\
136(19.7) \\
117(16.9) \\
93(13.5) \\
92(13.3)\end{array}$ & $\begin{array}{l}214(31.1) \\
149(21.6) \\
125(18.1) \\
104(15.1) \\
101(14.6)\end{array}$ & $\begin{array}{l}572(83.0) \\
477(69.2) \\
485(70.3) \\
399(57.9) \\
310(45.0)\end{array}$ & $\begin{array}{l}59.35 \\
37.30 \\
42.35 \\
43.00 \\
28.87\end{array}$ & $\begin{array}{l}81.00 \\
52.25 \\
54.40 \\
61.19 \\
43.90\end{array}$ & $\begin{array}{l}67.66 \\
43.54 \\
47.53 \\
51.55 \\
41.35\end{array}$ & $\begin{array}{l}78.89 \\
74.42 \\
69.18 \\
65.35 \\
43.57\end{array}$ & $\begin{array}{r}299 \\
147 \\
166 \\
144 \\
80\end{array}$ & $\begin{array}{r}3612 \\
1771 \\
2000 \\
1745 \\
966\end{array}$ \\
\hline \multicolumn{13}{|c|}{$13 \times 219-\operatorname{mm}(1 / 2 \times 85 / 8$-in. $)$ Pipe } \\
\hline $\begin{array}{l}17642 \\
17643 \\
17644 \\
17645 \\
17646\end{array}$ & $\begin{array}{r}25 \\
204 \\
427 \\
593 \\
649\end{array}$ & $\begin{array}{r}77 \\
400 \\
800 \\
1100 \\
1200\end{array}$ & $\begin{array}{r}152(22.1) \\
84(12.2) \\
78(11.3) \\
62(9.0) \\
52(7.6)\end{array}$ & $\begin{array}{r}197(28.6) \\
123(17.9) \\
109(15.8) \\
97(14.1) \\
86(12.5)\end{array}$ & $\begin{array}{r}216(31.4) \\
143(20.7) \\
120(17.4) \\
102(14.8) \\
99(14.3)\end{array}$ & $\begin{array}{l}571(82.8) \\
479(69.5) \\
489(70.9) \\
404(58.5) \\
310(44.9)\end{array}$ & $\begin{array}{l}59.53 \\
36.70 \\
45.42 \\
44.40 \\
28.13\end{array}$ & $\begin{array}{l}67.87 \\
51.40 \\
57.30 \\
59.85 \\
38.80\end{array}$ & $\begin{array}{l}69.53 \\
42.94 \\
50.09 \\
50.10 \\
37.20\end{array}$ & $\begin{array}{l}78.38 \\
72.34 \\
68.38 \\
63.61 \\
36.18\end{array}$ & $\begin{array}{r}299 \\
144 \\
180 \\
151 \\
79\end{array}$ & $\begin{array}{r}3609 \\
1734 \\
2177 \\
1829 \\
950\end{array}$ \\
\hline \multicolumn{13}{|c|}{$10 \times 406-\mathrm{mm}(0.4 \times 16-i \mathrm{n})$ Pipe } \\
\hline $\begin{array}{l}17647 \\
17648 \\
17649 \\
17650 \\
17651\end{array}$ & $\begin{array}{r}25 \\
204 \\
427 \\
593 \\
649\end{array}$ & $\begin{array}{r}77 \\
400 \\
800 \\
1100 \\
1200\end{array}$ & $\begin{array}{r}147(21.3) \\
72(10.5) \\
80(11.6) \\
75(10.8) \\
79(11.5)\end{array}$ & $\begin{array}{r}64(28.5) \\
123(17.8) \\
103(15.0) \\
92(13.4) \\
91(13.2)\end{array}$ & $\begin{array}{r}208(30.2) \\
132(19.1) \\
109(15.8) \\
95(13.8) \\
94(13.6)\end{array}$ & $\begin{array}{l}569(82.6) \\
475(68.9) \\
483(70.0) \\
395(57.3) \\
315(45.7)\end{array}$ & $\begin{array}{l}64.19 \\
38.52 \\
42.60 \\
43.82 \\
27.75\end{array}$ & $\begin{array}{l}84.55 \\
52.25 \\
56.40 \\
60.05 \\
42.00\end{array}$ & $\begin{array}{l}71.45 \\
43.05 \\
45.35 \\
50.85 \\
43.98\end{array}$ & $\begin{array}{l}76.77 \\
72.84 \\
69.27 \\
68.27 \\
43.83\end{array}$ & $\begin{array}{r}319 \\
148 \\
163 \\
147 \\
77\end{array}$ & $\begin{array}{r}3855 \\
1784 \\
1966 \\
1772 \\
936\end{array}$ \\
\hline \multicolumn{13}{|c|}{$10 \times 711-\mathrm{mm}(0.4 \times 28-\mathrm{in}$.$) Pipe$} \\
\hline $\begin{array}{l}17652 \\
17653 \\
17654 \\
17655 \\
17656\end{array}$ & $\begin{array}{r}25 \\
204 \\
427 \\
593 \\
649\end{array}$ & $\begin{array}{r}77 \\
400 \\
800 \\
1100 \\
1200\end{array}$ & $\begin{array}{r}140(20.3) \\
62(9.0) \\
75(10.8) \\
50(7.3) \\
81(11.7)\end{array}$ & $\begin{array}{r}191(27.7) \\
117(16.9) \\
97(14.1) \\
82(11.9) \\
84(12.2)\end{array}$ & $\begin{array}{r}203(29.5) \\
128(18.5) \\
105(15.2) \\
90(13.0) \\
89(12.9)\end{array}$ & $\begin{array}{l}563(81.6) \\
470(68.2) \\
477(69.1) \\
392(56.8) \\
309(44.8)\end{array}$ & $\begin{array}{l}61.97 \\
39.46 \\
43.99 \\
48.36 \\
29.40\end{array}$ & $\begin{array}{l}84.30 \\
54.60 \\
57.10 \\
52.25 \\
40.80\end{array}$ & $\begin{array}{l}71.08 \\
45.49 \\
48.65 \\
53.55 \\
38.50\end{array}$ & $\begin{array}{l}79.53 \\
73.80 \\
68.32 \\
56.56 \\
34.45\end{array}$ & $\begin{array}{r}307 \\
148 \\
164 \\
160 \\
79\end{array}$ & $\begin{array}{r}3710 \\
1794 \\
1981 \\
1938 \\
952\end{array}$ \\
\hline \multicolumn{13}{|c|}{ 25-mm $\left(1-i n_{.}\right)$Bar } \\
\hline $\begin{array}{l}17622 \\
17623 \\
17624 \\
17625 \\
17626\end{array}$ & $\begin{array}{r}25 \\
204 \\
427 \\
593 \\
649\end{array}$ & $\begin{array}{r}77 \\
400 \\
800 \\
1100 \\
1200\end{array}$ & $\begin{array}{r}126(18.3) \\
93(13.5) \\
76(11.0) \\
72(10.4) \\
69(10.0)\end{array}$ & $\begin{array}{l}206(29.9) \\
143(20.8) \\
122(17.7) \\
105(15.2) \\
103(14.9)\end{array}$ & $\begin{array}{l}228(33.0) \\
161(23.3) \\
135(19.6) \\
117(16.9) \\
115(16.7)\end{array}$ & $\begin{array}{l}573(83.1) \\
477(69.2) \\
485(70.3) \\
407(59.0) \\
317(45.9)\end{array}$ & $\begin{array}{l}58.28 \\
35.94 \\
37.60 \\
38.66 \\
26.80\end{array}$ & $\begin{array}{l}80.30 \\
52.10 \\
55.05 \\
59.12 \\
50.58\end{array}$ & $\begin{array}{l}67.45 \\
43.34 \\
47.50 \\
49.94 \\
42.79\end{array}$ & $\begin{array}{l}79.24 \\
74.90 \\
70.38 \\
61.19 \\
44.17\end{array}$ & $\begin{array}{r}295 \\
141 \\
145 \\
132 \\
76\end{array}$ & $\begin{array}{r}3564 \\
1707 \\
1756 \\
1591 \\
916\end{array}$ \\
\hline \multicolumn{13}{|c|}{ 51-mm (2-in.) Bar } \\
\hline $\begin{array}{l}17627 \\
17628 \\
17629 \\
17630 \\
17631\end{array}$ & $\begin{array}{r}25 \\
204 \\
427 \\
593 \\
649\end{array}$ & $\begin{array}{r}77 \\
400 \\
800 \\
1100 \\
1200\end{array}$ & $\begin{array}{r}112(16.3) \\
90(13.0) \\
90(13.1) \\
55(7.9) \\
66(9.6)\end{array}$ & $\begin{array}{r}190(27.6) \\
123(17.9) \\
114(16.5) \\
94(13.6) \\
90(13.0)\end{array}$ & $\begin{array}{l}213(31.0) \\
141(20.5) \\
122(17.7) \\
104(15.1) \\
103(14.9)\end{array}$ & $\begin{array}{l}563(81.7) \\
470(68.1) \\
482(69.9) \\
400(58.0) \\
308(44.7)\end{array}$ & $\begin{array}{l}61.92 \\
39.43 \\
42.96 \\
44.52 \\
29.30\end{array}$ & $\begin{array}{l}84.65 \\
53.20 \\
53.40 \\
59.15 \\
48.05\end{array}$ & $\begin{array}{l}69.81 \\
45.64 \\
47.25 \\
52.10 \\
40.61\end{array}$ & $\begin{array}{l}80.45 \\
75.71 \\
68.59 \\
62.43 \\
43.83\end{array}$ & $\begin{array}{r}307 \\
152 \\
165 \\
150 \\
80\end{array}$ & $\begin{array}{r}3714 \\
1834 \\
1999 \\
1815 \\
969\end{array}$ \\
\hline \multicolumn{13}{|c|}{ 64-min $(2.5-\mathrm{in.})$ Bar } \\
\hline $\begin{array}{l}17632 \\
17633 \\
17634 \\
17635 \\
17636\end{array}$ & $\begin{array}{r}25 \\
204 \\
427 \\
593 \\
649\end{array}$ & $\begin{array}{r}77 \\
400 \\
800 \\
1100 \\
1200\end{array}$ & $\begin{array}{r}135(19.5) \\
112(16.3) \\
90(13.1) \\
74(10.7) \\
75(10.8)\end{array}$ & $\begin{array}{l}193(28.0) \\
150(21.8) \\
129(18.7) \\
111(16.1) \\
104(15.1)\end{array}$ & $\begin{array}{l}215(31.2) \\
169(24.5) \\
144(20.9) \\
124(18.0) \\
121(17.6)\end{array}$ & $\begin{array}{l}567(82.2) \\
475(68.9) \\
494(71.6) \\
408(59.1) \\
309(44.8)\end{array}$ & $\begin{array}{l}59.21 \\
36.11 \\
43.35 \\
42.35 \\
26.81\end{array}$ & $\begin{array}{l}80.00 \\
52.15 \\
43.35 \\
55.51 \\
41.20\end{array}$ & $\begin{array}{l}67.53 \\
42.93 \\
46.80 \\
47.03 \\
42.04\end{array}$ & $\begin{array}{l}80.35 \\
76.15 \\
71.58 \\
65.00 \\
41.71\end{array}$ & $\begin{array}{r}294 \\
142 \\
175 \\
148 \\
74\end{array}$ & $\begin{array}{r}3547 \\
1721 \\
2120 \\
1785 \\
891\end{array}$ \\
\hline
\end{tabular}

a Specimen broke at gage marks. 


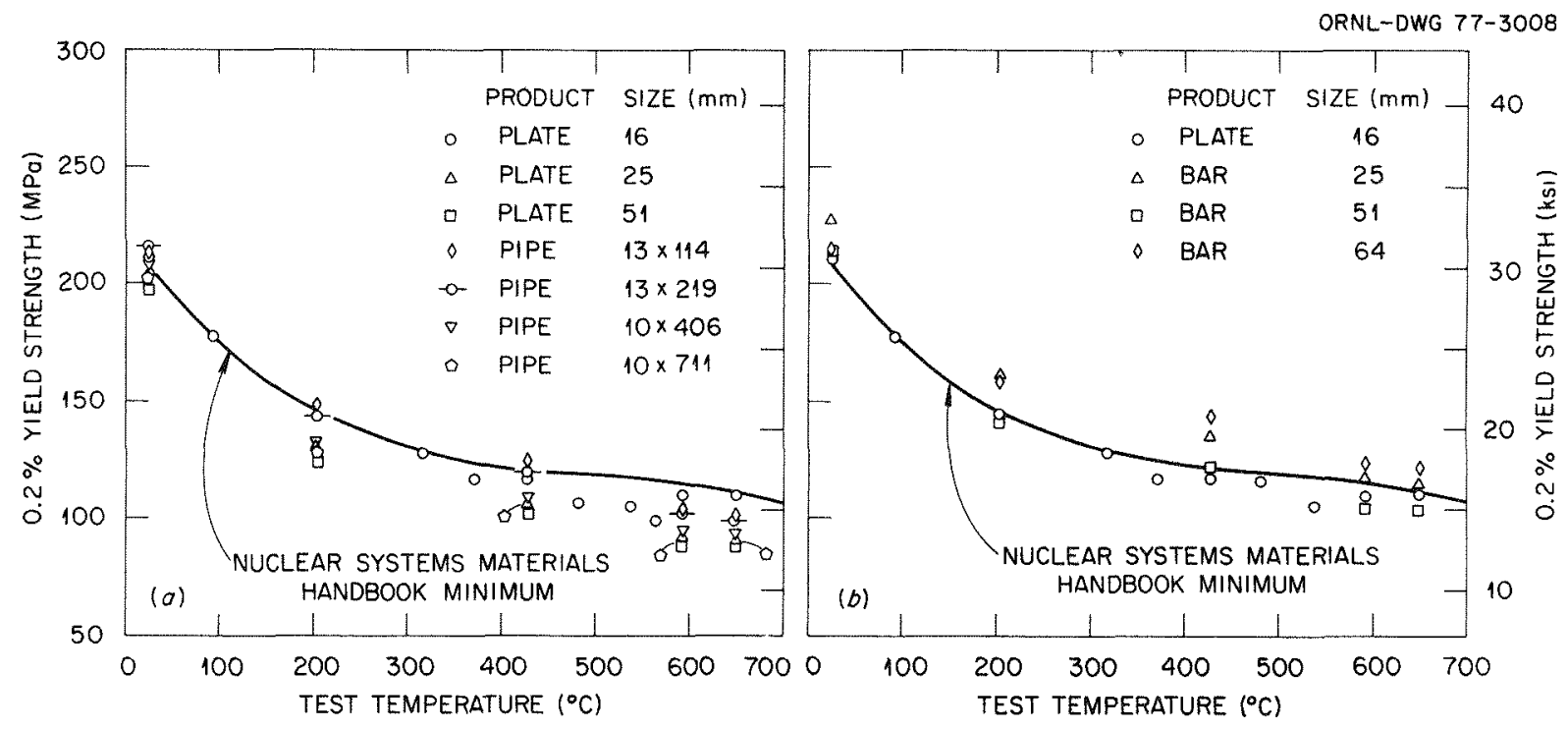

Fig. 23. The $0.2 \%$ Yield Strength as a Function of Test Temperature for Various Products of the Reference Heat (8092297) of Type 316 Stainless Steel in the Reannealed Condition $\left(0.5 \mathrm{hr}\right.$ at $1065^{\circ} \mathrm{C}$ ) at a Strain Rate of $0.004 / \mathrm{min}$. (a) Plate and pipe. (b) 16-mm (5/8-in.) plate and bar.

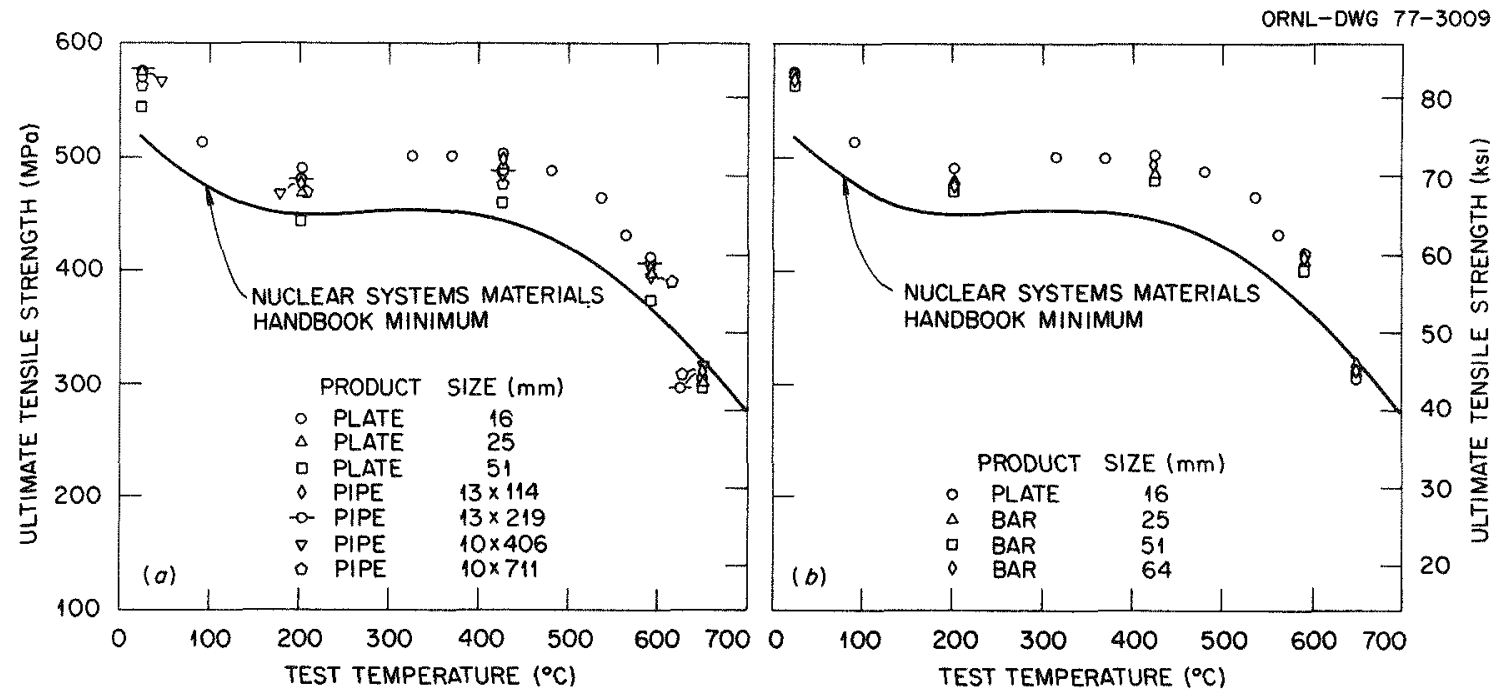

Fig. 24. The Ultimate Tensile Strength as a Function of Test Temperature for Various Products of the Reference Heat (8092297) of Type 316 Stainless Steel in the Reannealed Condition at a Strain Rate of $0.004 / \mathrm{min}$. (a) Plate and pipe. (b) 16-mm (5/8-in.) plate and bar. 

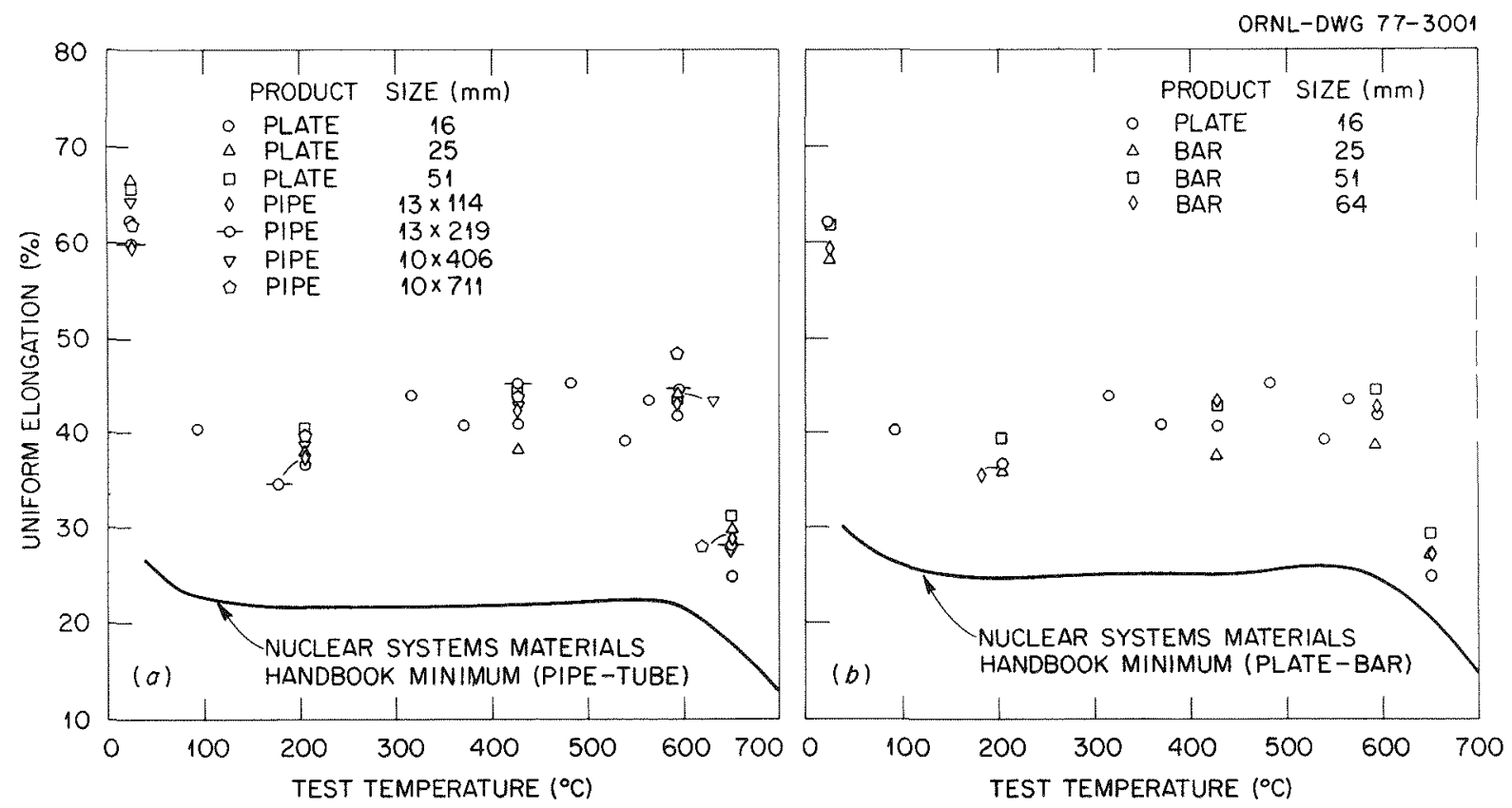

Fig. 25. The Uniform Elongation as a Function of Test Temperature for Various Products of the Reference Heat (8092297) of Type 316 Stainless Steel in the Reannealed Condition at a Strain Rate of $0.004 / \mathrm{min}$. (a) Plate and pipe. (b) 16-mm (5/8-in.) plate and bar.

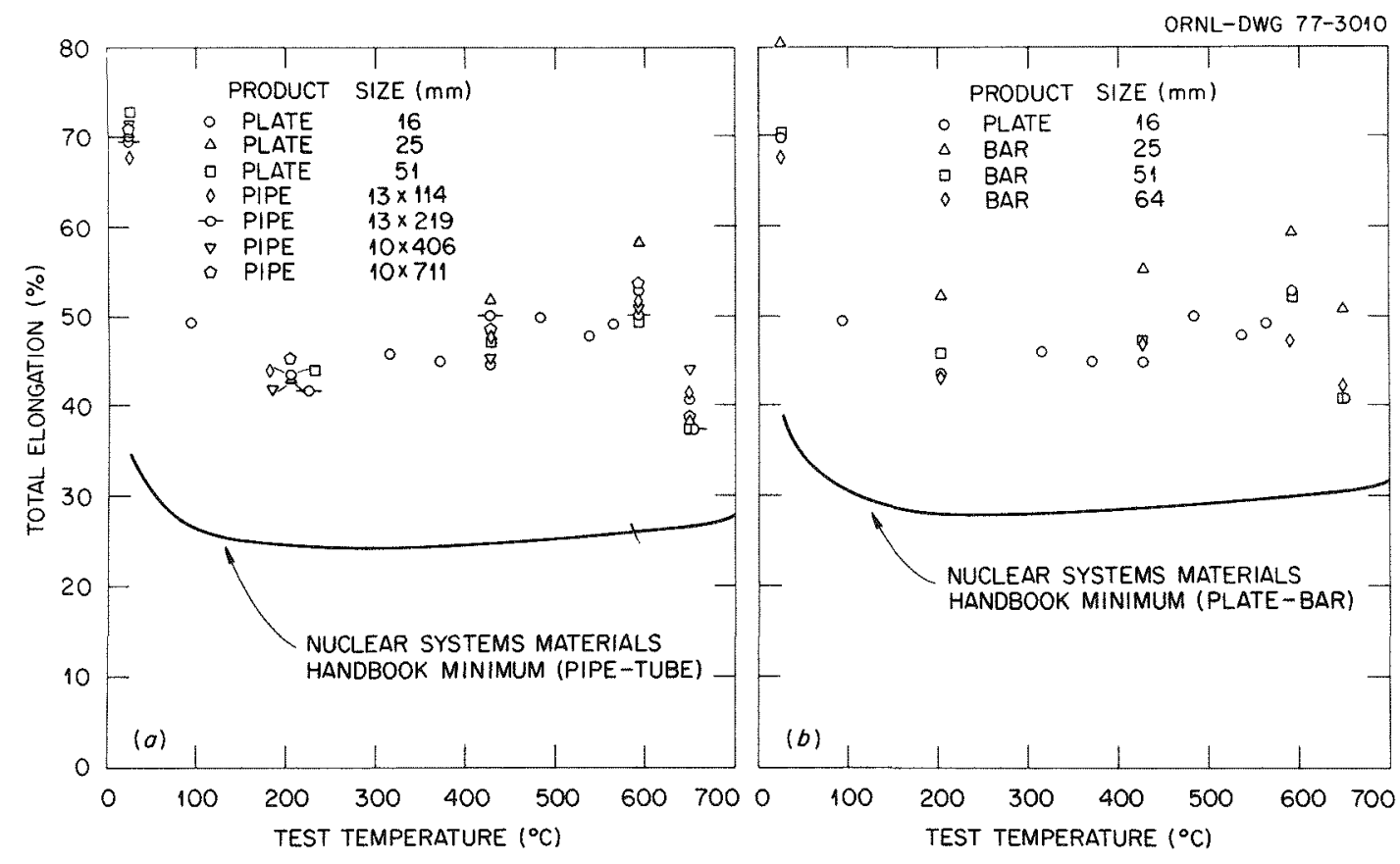

Fig. 26. The Total Elongation as a Function of Test Temperature for Various Products of the Reference Heat (8092297) of Type 316 Stainless Stee1 in the Reannealed Condition at a Strain Rate of $0.004 / \mathrm{min}$. (a) Plate and pipe. (b) 16-mm (5/8-in.) plate and bar. 


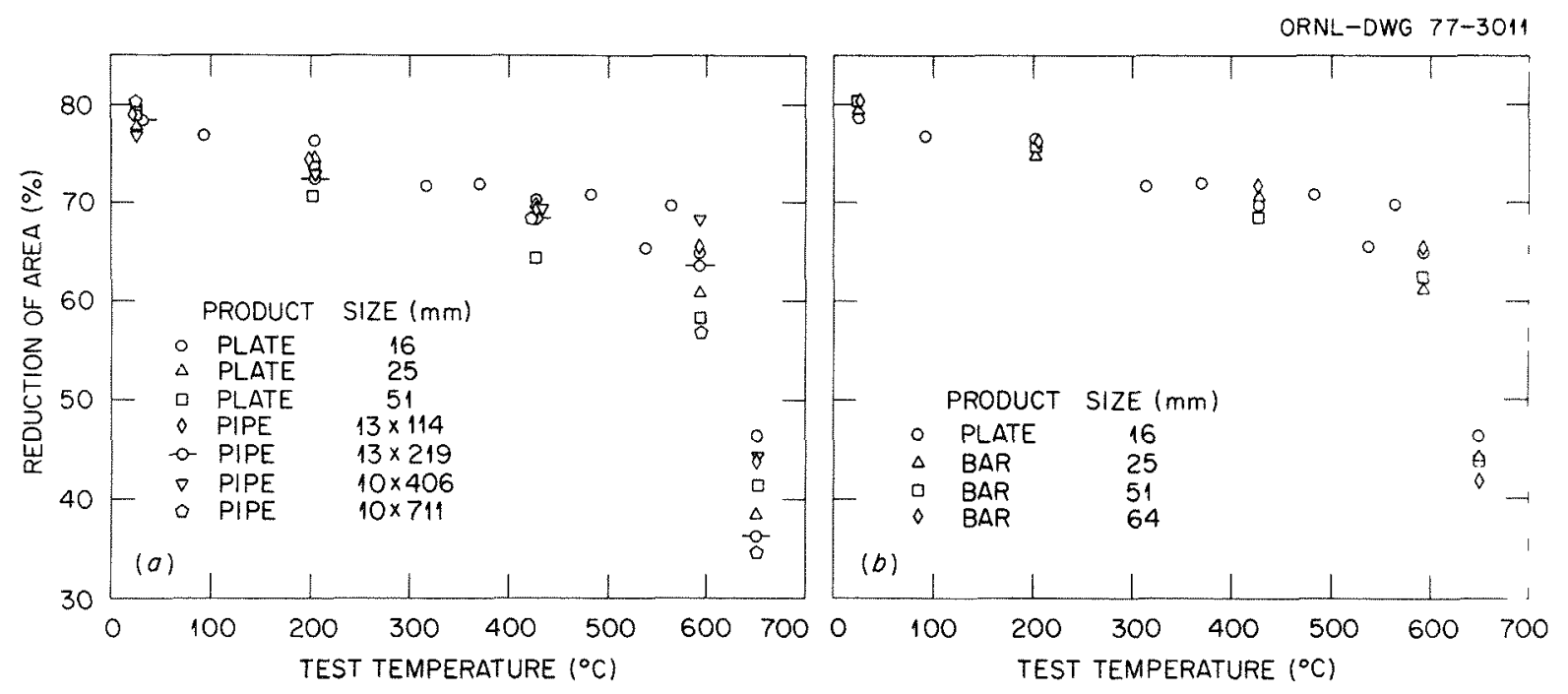

Fig. 27. The Reduction of Area as a Function of Test Temperature for Various Products of the Reference Heat (8092297) of Type 316 Stainless Steel in the Reannealed Condition at a Strain Rate of $0.004 / \mathrm{min}$. (a) Plate and pipe. (b) 16-mm (5/8-in.) plate and bar.

tensile strengths for a11 product forms were above the Handbook minimum curve for all test temperatures except $649^{\circ} \mathrm{C}\left(1200^{\circ} \mathrm{F}\right)$. Strain-rate sensitivity of ultimate tensile strength at $649^{\circ} \mathrm{C}$ may explain why the observed values fall below the minimum curve. Ultimate tensile strength values for all products in the reannealed condition showed a slight increase in the temperature range from 300 to $500^{\circ} \mathrm{C}\left(570-930^{\circ} \mathrm{F}\right)$, and this is associated with possible dynamic strain aging effects.

Uniform Elongation - Uniform elongation data for all product forms in the reannealed condition were above the Handbook minimum for the whole temperature range of this investigation. Reannealing, which removes the residual processing and straightening work from these products, increased their uniform elongation by 1.5 to $6 \%$. Dynamic strain aging over the range 300 to $500^{\circ} \mathrm{C}$ resulted in increased values of uniform elongation for all product forms.

Total Elongation - Total elongation values for a11 reannealed product forms were above the Handbook minimum curve. Reannealing increased the total elongation of all products by 1.5 to $6 \%$. Dynamic strain-aging effects observed for ultimate tensile strength and uniform elongation were also observed for total elongation. The experimentally 
observed sharp drop in total elongation at $649^{\circ} \mathrm{C}\left(1200^{\circ} \mathrm{F}\right)$ for as-received material, Fig. 20 was also observed in reannealed material. Such a drop is associated with tensile ductility minimum conditions, which are discussed elsewhere. 17

Reduction of Area - Reduction of area values for various product forms in the reannealed condition are plotted in Fig. 27. The Handbook does not contain any minimum value for this property. However, it is interesting to note that reductions of area for all product forms were essentially the same, and all showed a sharp drop at $649^{\circ} \mathrm{C}$. Such a drop is again associated with the ductility minimum, which is discussed elsewhere. ${ }^{17}$

Work to Plastic Instability - The area under the stress-strain curve up to the ultimate tensile strength point is a measure of toughness of the material. Values of this quantity were computed for various product forms in the reannealed condition and are displayed as a function of test temperature in Fig. 28. The toughness of reannealed product forms showed trends similar to those observed for the as-received material in Fig. 22.

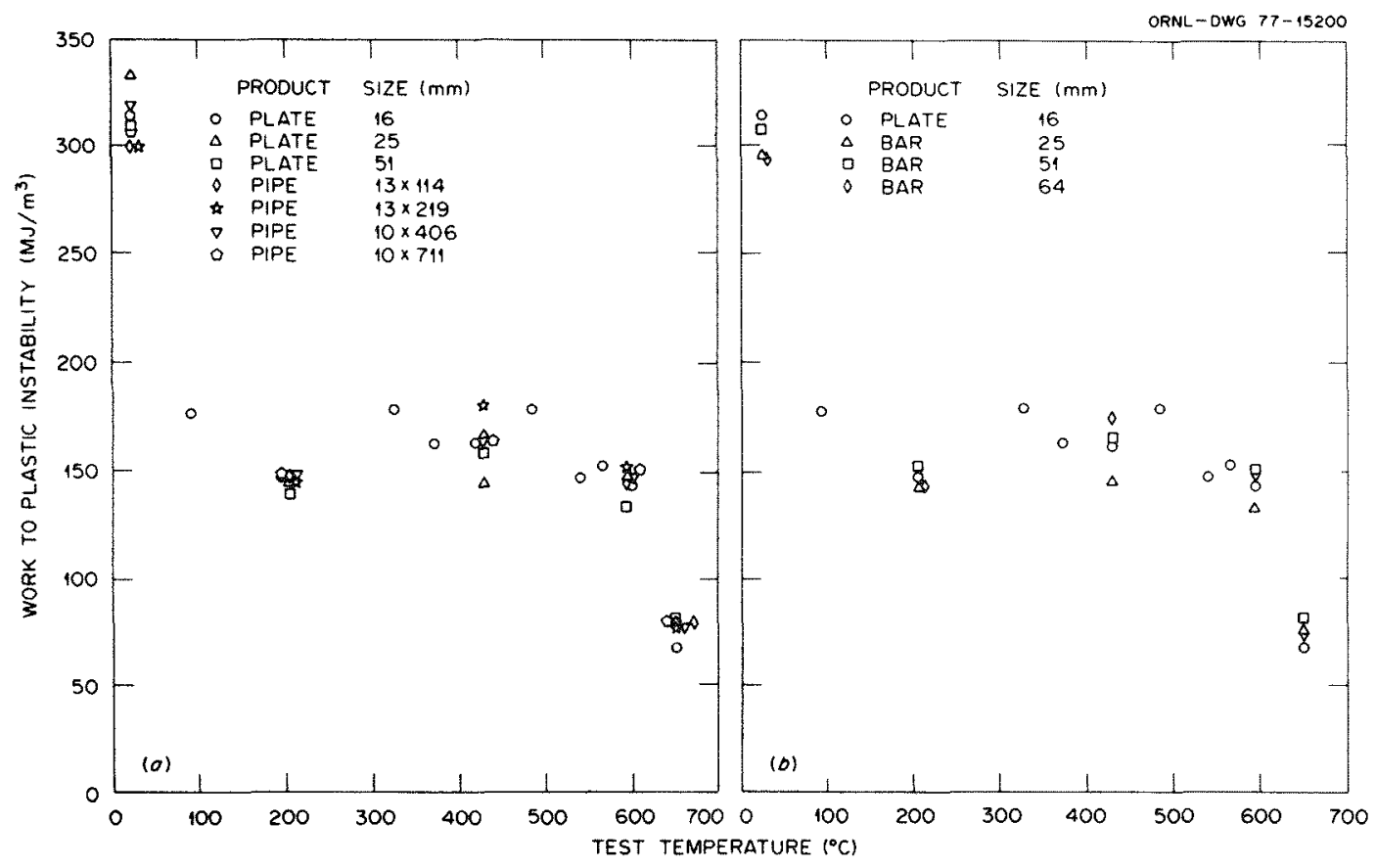

Fig. 28. Work to Plastic Instability as a Function of Test Temperature for Various Products of the Reference Heat (8092297) of Type 316 Stainless Steel in the Reannealed Condition at a Strain Rate of $0.004 / \mathrm{min}$. (a) Plate and pipe. (b) 16-mm (5/8-in.) plate and bar. 
Estimate of Residual Cold Work in Various Product Forms from Tensile Properties in As-Received and Reannealed Material

To determine the amount of residual cold work in various products, we have plotted the $0.2 \%$ yield strength of the reannealed material as a function of its value in the as-received condition. These values are plotted in Fig. 29 for the temperature range from room temperature to

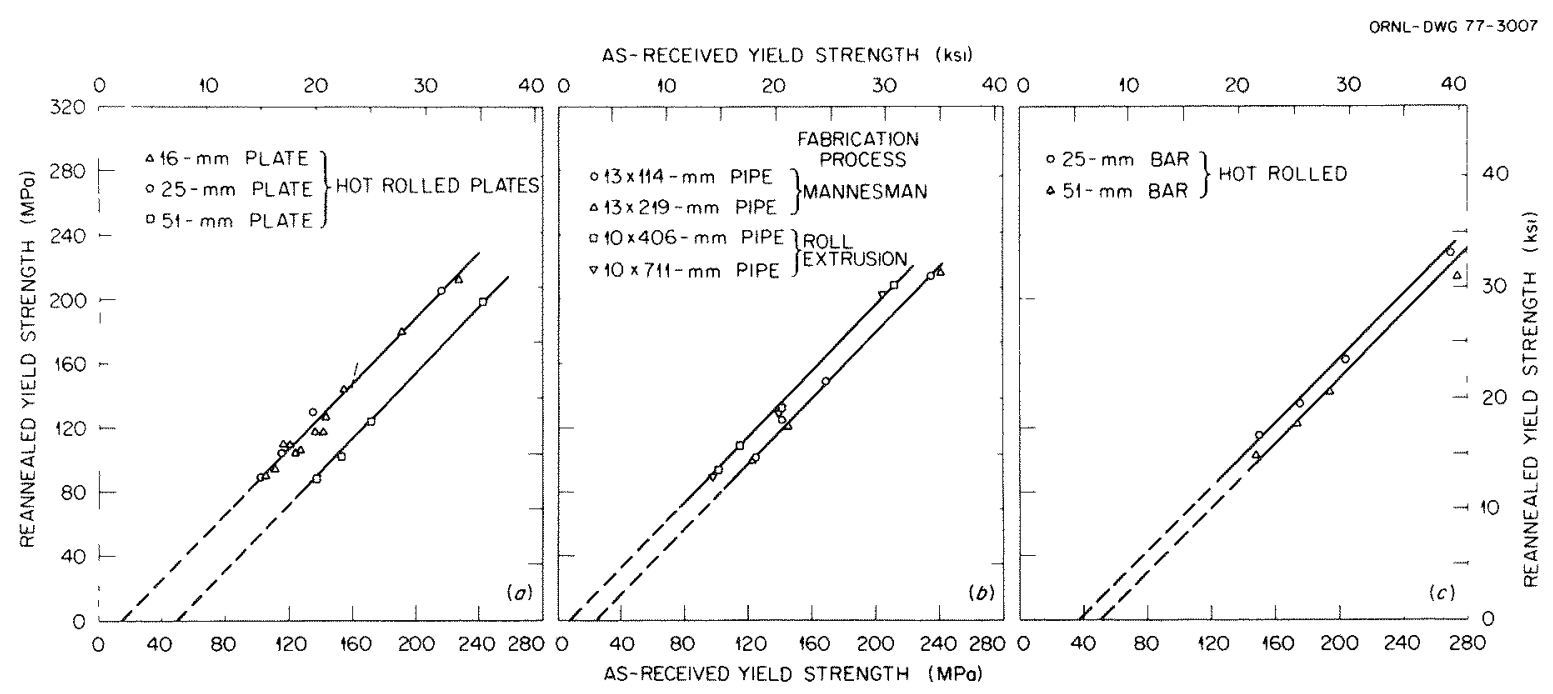

Fig. 29. Reannealed Yield Strength as a Function of As-Received Yield Strength for Various Products of the Reference Heat (8092297) of Type 316 Stainless Steel at a Strain Rate of $0.004 / \mathrm{min}$. (a) Plate. (b) Pipe. (c) Bar.

$649^{\circ} \mathrm{C}\left(1200^{\circ} \mathrm{F}\right)$. For $16-\mathrm{mm}\left(5 / 8-\mathrm{in}_{\text {. }}\right)$ plate these values extend to a test temperature of $760^{\circ} \mathrm{C}\left(1400^{\circ} \mathrm{F}\right)$. This figure indicates that the reannealed yield strength can be linearly related to as-received yield strength by the following expression:

$$
S_{y}^{\mathrm{RA}}=A+B S_{y}^{\mathrm{AR}}
$$

where

$S_{y}^{\mathrm{RA}}=0.2 \%$ yield strength in the reannealed condition, $S_{y}^{\mathrm{AR}}=0.2 \%$ yield strength in the as-received condition, $A, B=$ constants. 
Previous work ${ }^{9}$ has shown that $A$ and $B$ can be expressed as:

$$
\begin{aligned}
& A=S_{0}{ }^{\mathrm{RA}}-s_{0} \sqrt[\mathrm{AR}]{d_{\mathrm{AR}} / d_{\mathrm{RA}}} \\
& B=\sqrt{d_{\mathrm{AR}} / d_{\mathrm{RA}}}
\end{aligned}
$$

where

$$
\begin{aligned}
d_{\mathrm{AR}} & =\text { as-received grain size, } \\
d_{\mathrm{RA}} & =\text { reannealed grain size, } \\
S_{0}{ }^{\mathrm{AR}} & =\text { as-received frictional stress, } \\
S_{0}{ }^{\mathrm{RA}} & =\text { reannealed frictional stress. }
\end{aligned}
$$

Figure 30 shows reannealed grain size as a function of as-received grain size from Table 2. Data in this figure can be represented by:

$$
d_{\mathrm{RA}}=d_{\mathrm{AR}}
$$

Equation (4) indicates that the reannealing treatment does not produce grain growth in any of the ten product forms. Substituting Eq. (4) in Eqs. (2) and (3) gives the following:

$$
A=S_{0}^{\mathrm{RA}}-S_{0}^{\mathrm{AR}}
$$

and

$$
B=1
$$

When grain size does not change on reannealing, Eq. (5) represents a measure of the residual cold work.

To get a measure of residual cold work, we have drawn lines with $B=1$ in Fig. 29. Results from this figure are summarized in Table 9. The residual cold work values listed are in terms of stress. To measure residual cold work in terms of strain, we have plotted reannealed uniform 


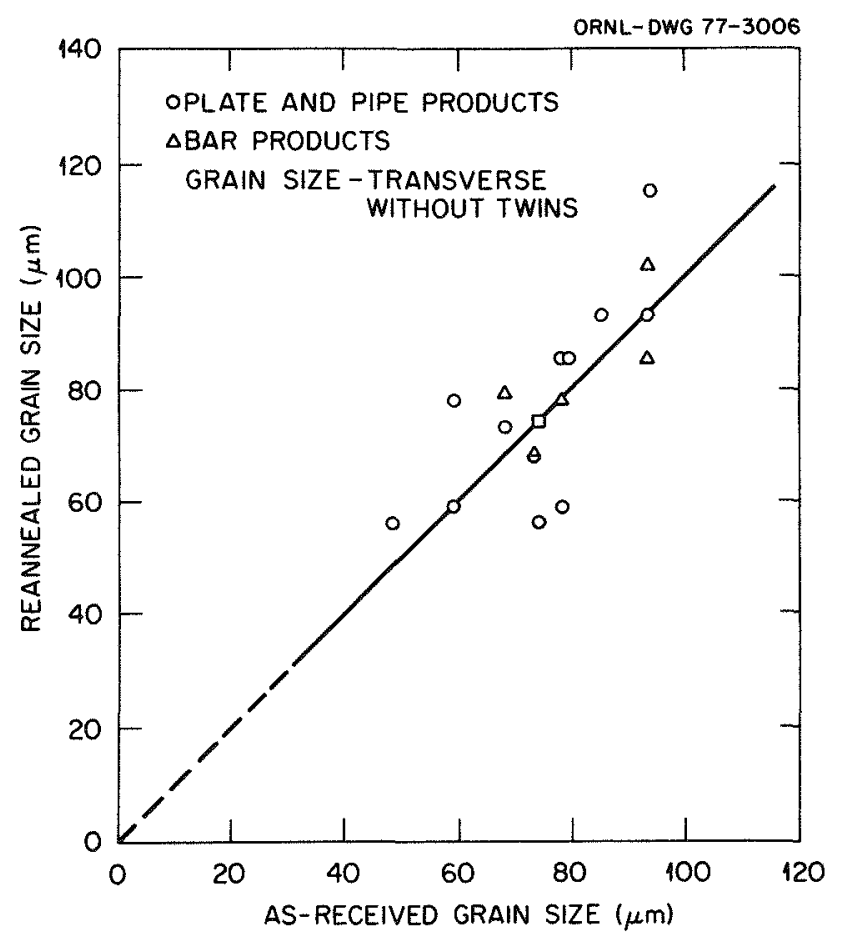

Fig. 30. Reannealed Grain Size as a Function of As-Received Grain Size for Various Products of the Reference Heat (8092297) of Type 316 Stainless Steel.

Table 9. Summary of Residual Cold Work in Various MillAnnealed Product Forms of the Reference Heat (8092297) of Type 316 Stainless Steel

\begin{tabular}{lccccc}
\hline \multirow{2}{*}{ Product Form } & $\begin{array}{c}\text { Size } \\
(\mathrm{mm})\end{array}$ & \multicolumn{2}{c}{ Residual Cold Work } & \multicolumn{1}{c}{$\begin{array}{c}\text { Fabrication } \\
\text { Process }\end{array}$} \\
& & $(\mathrm{MPa})^{\mathrm{a}}$ & $(\mathrm{ksi})^{\mathrm{a}}$ & $(\%)^{\mathrm{b}}$ & \\
\hline Plate & 16 & 16 & 2.3 & 2 & Hot Rolled \\
Plate & 25 & 16 & 2.3 & 2 & Hot Rolled \\
Plate & 51 & 50 & 7.2 & 6.5 & Hot Rolled \\
Pipe & $114 \times 13$ & 24 & 3.5 & 4.5 & Mannesman \\
Pipe & $219 \times 13$ & 24 & 3.5 & 4.5 & Mannesman \\
Pipe & $406 \times 10$ & 8 & 1.2 & 1.5 & Roll Extrusion \\
Pipe & $711 \times 10$ & 8 & 1.2 & 1.5 & Roll Extrusion \\
Bar & 25 & 38 & 5.5 & 3.0 & Hot Rolled \\
Bar & 51 & 52 & 7.5 & 5.5 & Hot Rolled \\
Barc & 64 & & & & Hot Rolled \\
\hline
\end{tabular}

arom $0.2 \%$ yield strength.

$\mathrm{b}_{\text {From uniform elongation. }}$

${ }^{c}$ Could not be determined because of nonuniform cold work. 
elongation as a function of as-received uniform elongation in Fig. 31. Using the procedure of Fig. 29, we have determined the percentage residual strains and summarized them in Table 9. Table 9 shows that estimated residual cold work is different for different product forms. In general, hot-rolled mill-annealed plates show less cold work than bar products. The unusually high residual cold work in 51-mm (2-in.) plate is possibly a result of taking specimens from the top level of three possible levels (top, middle, and bottom). This also suggests that residual cold work may be nonuniform through the cross section of a given product. Residual cold work in various pipes shows that it is a function of fabrication process. The roll extrusion process appears to introduce the minimum amount of residual cold work.

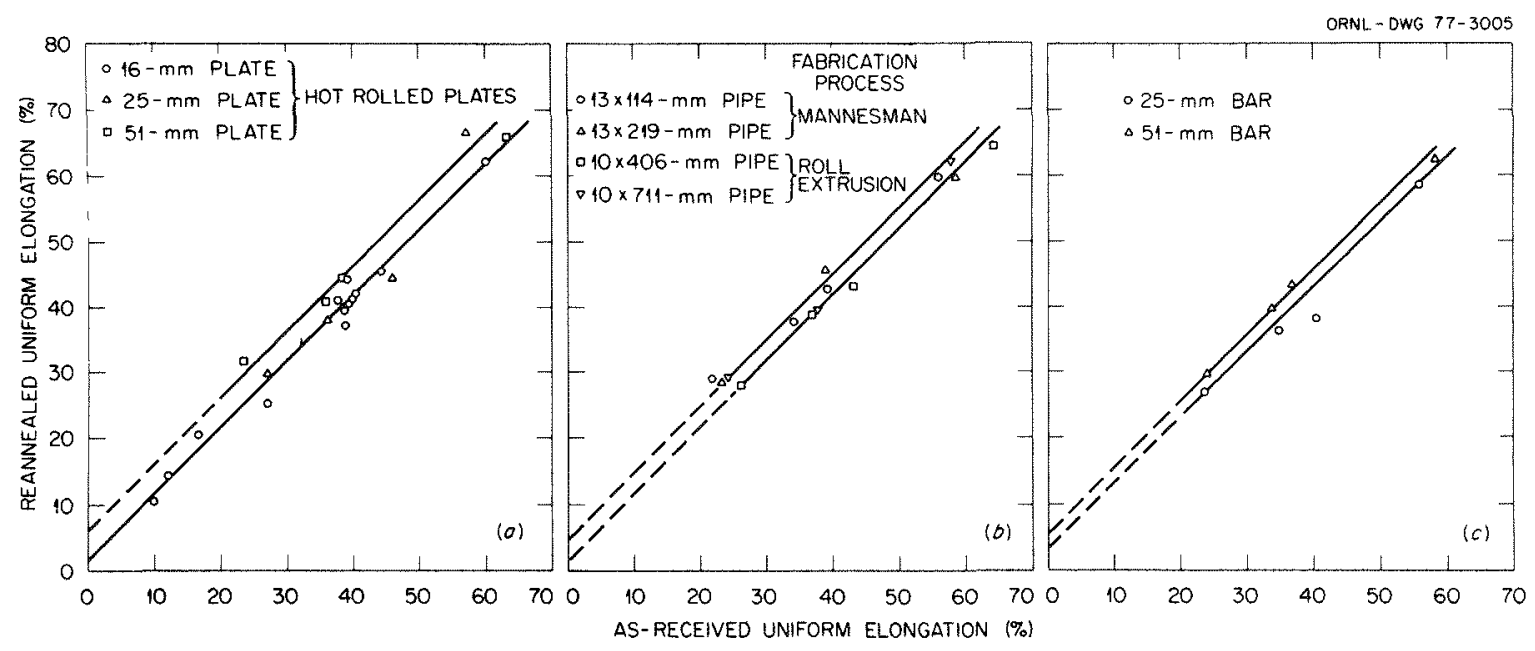

Fig. 31. Reannealed Uniform Elongation as a Function of As-Received Uniform Elongation for Various Products of the Reference Heat (8092297) of Type 316 Stainless Steel at a Strain Rate of $0.004 / \mathrm{min}$. (a) P1ate. (b) Pipe. (c) Bar.

The grain size can influence the yield strength, and the two are commonly related by the following equation:

$$
S_{y}=S_{0}+k d^{-1 / 2}
$$


where

$$
\begin{aligned}
& S_{y}=0.2 \% \text { yield strength, } \\
& S_{0}=\text { frictional stress, } \\
& k_{y}=\text { constant. }
\end{aligned}
$$

Figure 32 shows $0.2 \%$ yield strength plotted against $d^{-1 / 2}$ for all ten reannealed product forms. For $S_{y}$ in $\mathrm{MPa}$ and $d$ in $\mu \mathrm{m}$, constants $S_{0}$ and $k_{y}$ for ten product forms were 167.5 and 375 , respectively. This figure shows that the differences in $0.2 \%$ yield strength of various product forms in the reannealed condition can be accounted, for the most part, by slight grain size variation between the various product forms. Factors causing variation in grain size will be discussed in a later section.

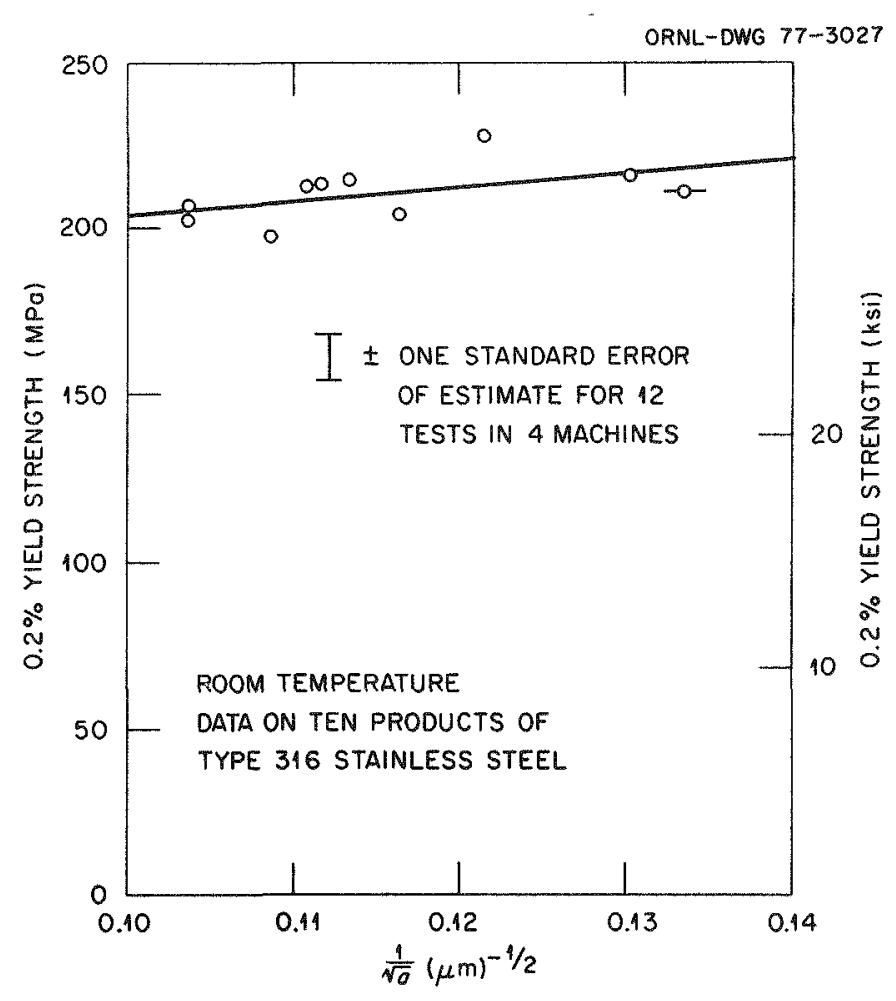

Fig. 32. The $0.2 \%$ Yield Strength as a Function of Grain Size for Various Products of the Reference Heat (8092297) of Type 316 Stainless Steel. These data are at room temperature and a strain rate of $0.004 / \mathrm{min}$. 
Modeling of Tensile Data for Various Product Forms

The $0.2 \%$ yield and ultimate tensile strength data from Tables 5 through 8 are plotted as a function of test temperature in Fig. 33 for as-received (mill-annealed) material and Fig. 34 for reannealed (laboratory annealed) material for all ten product forms. Similar plots for ductility quantities (uniform and total elongation and reduction of area) are shown in Figs. 35 and 36.

A third-degree polynomial was fit to the data:

$$
P=a_{0}+a_{1} T+a_{2} T^{2}+a_{3} T^{3}
$$

where

$$
\begin{aligned}
P & =\text { tensile property (strength in } \mathrm{MPa} \text { or ductility in } \% \text { ), } \\
T & =\text { test temperature, }{ }^{\circ} \mathrm{C}, \\
a_{i} & =\text { constants. }
\end{aligned}
$$

The goodness of fit was determined by $R^{2}$, the coefficient of determination. $\left(R^{2}=1.0\right.$ means that the model describes the data perfectly.) The constants in Eq. (8) were estimated by the method of least squares and are summarized in Table 10. The expected values based on $\mathrm{Eq}$. (8) have been plotted in Figs. 33 through 36. The variability about the expected values is measured by the standard error of estimate (SEE).

According to the SEE values in Table 10, all tensile properties showed significant product form variations in the as-received condition but not in the reannealed condition. Among other properties, $0.2 \%$ yield strength showed the maximum variation, which is consistent with similar observations made previous $1 y^{10,18}$ on type 304 stainless steel.

Equation (8) and constants in Table 10 have been used to compute expected and expected minus 2SEE values. The expected minus 2SEE values are computed to define the lower bound values, which have previously ${ }^{18,19}$ 

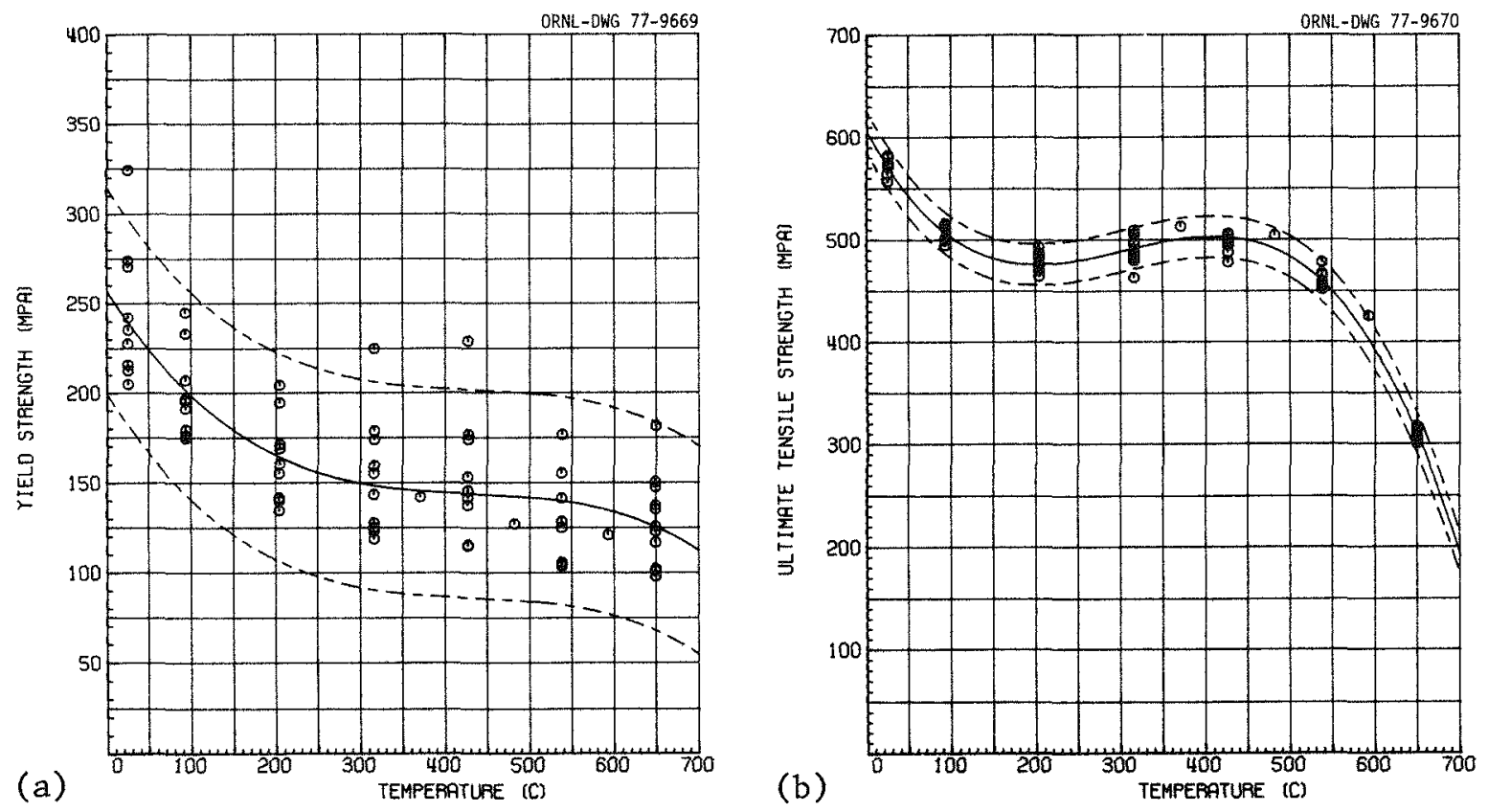

Fig. 33. The 0.2\% Yield and Ultimate Tensile Strength as Functions of Test Temperature for Ten Product Forms of the Reference Heat (8092297) of Type 316 Stainless Steel in the As-Received Condition at a Strain Rate of $0.004 / \mathrm{min}$. (a) Yield strength. (b) Ultimate tensile strength.
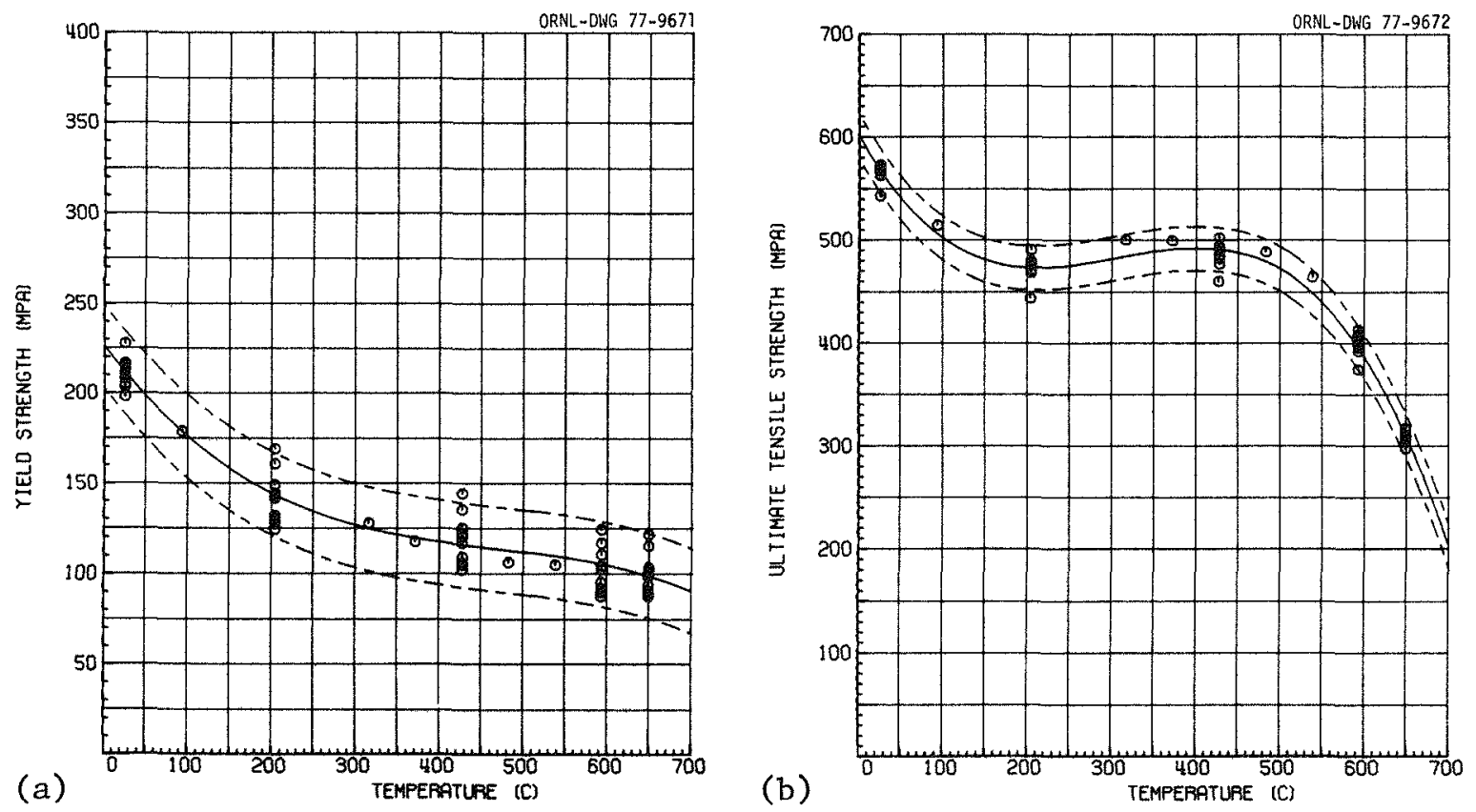

Fig. 34. The 0.2\% Yield and U1timate Tensile Strength as Functions of Test Temperature for Ten Product Forms of the Reference Heat (8092297) of Type 316 Stainless Steel in the Reannealed Condition $\left(0.5 \mathrm{hr}\right.$ at $\left.1065^{\circ} \mathrm{C}\right)$ at a Strain Rate of $0.004 / \mathrm{min}$. (a) Yield strength. (b) Ultimate tensile strength. 

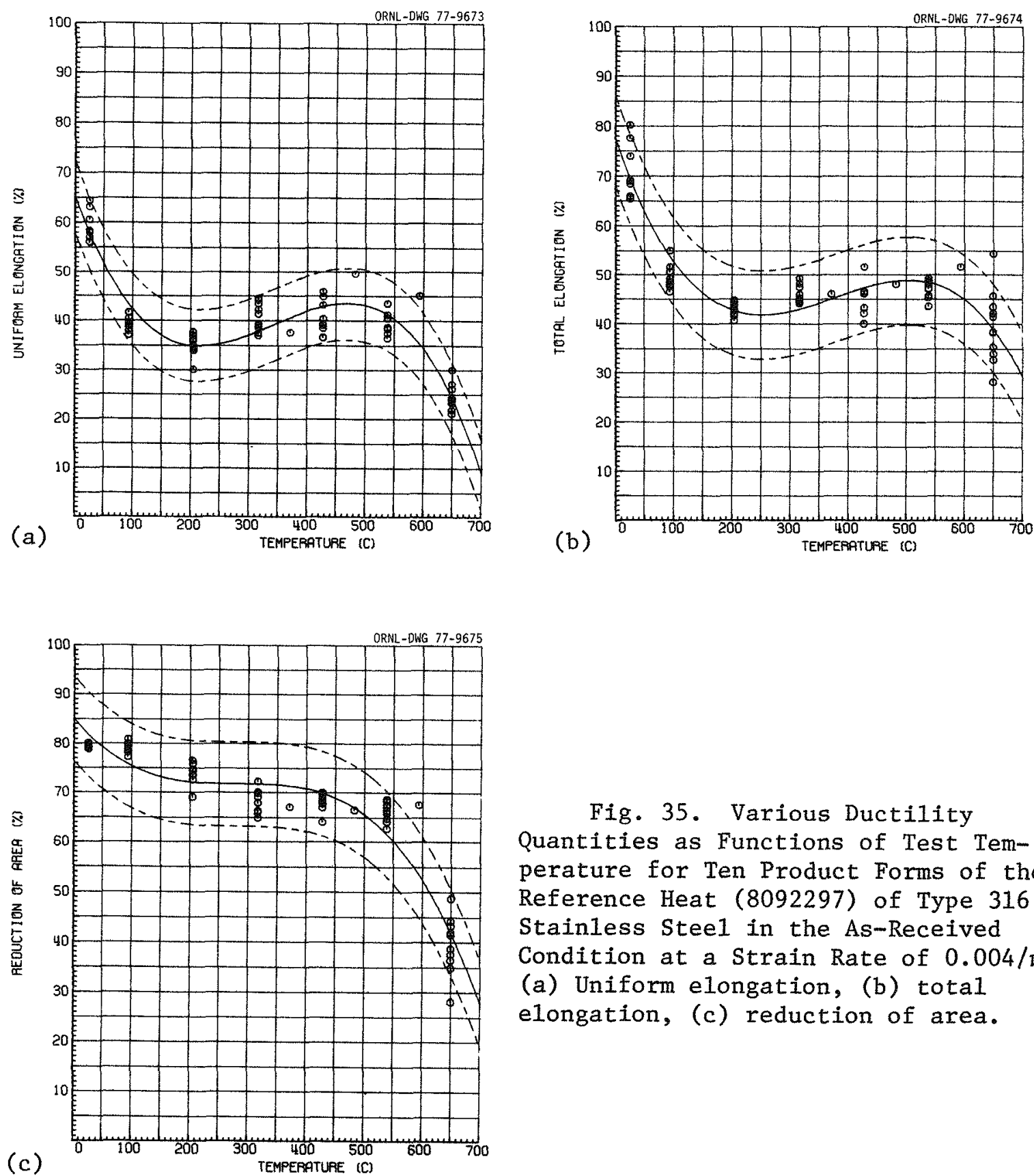

Fig. 35. Various Ductility Quantities as Functions of Test Temperature for Ten Product Forms of the Reference Heat (8092297) of Type 316 Stainless Steel in the As-Received Condition at a Strain Rate of $0.004 / \mathrm{min}$. (a) Uniform elongation, (b) total elongation, (c) reduction of area. 

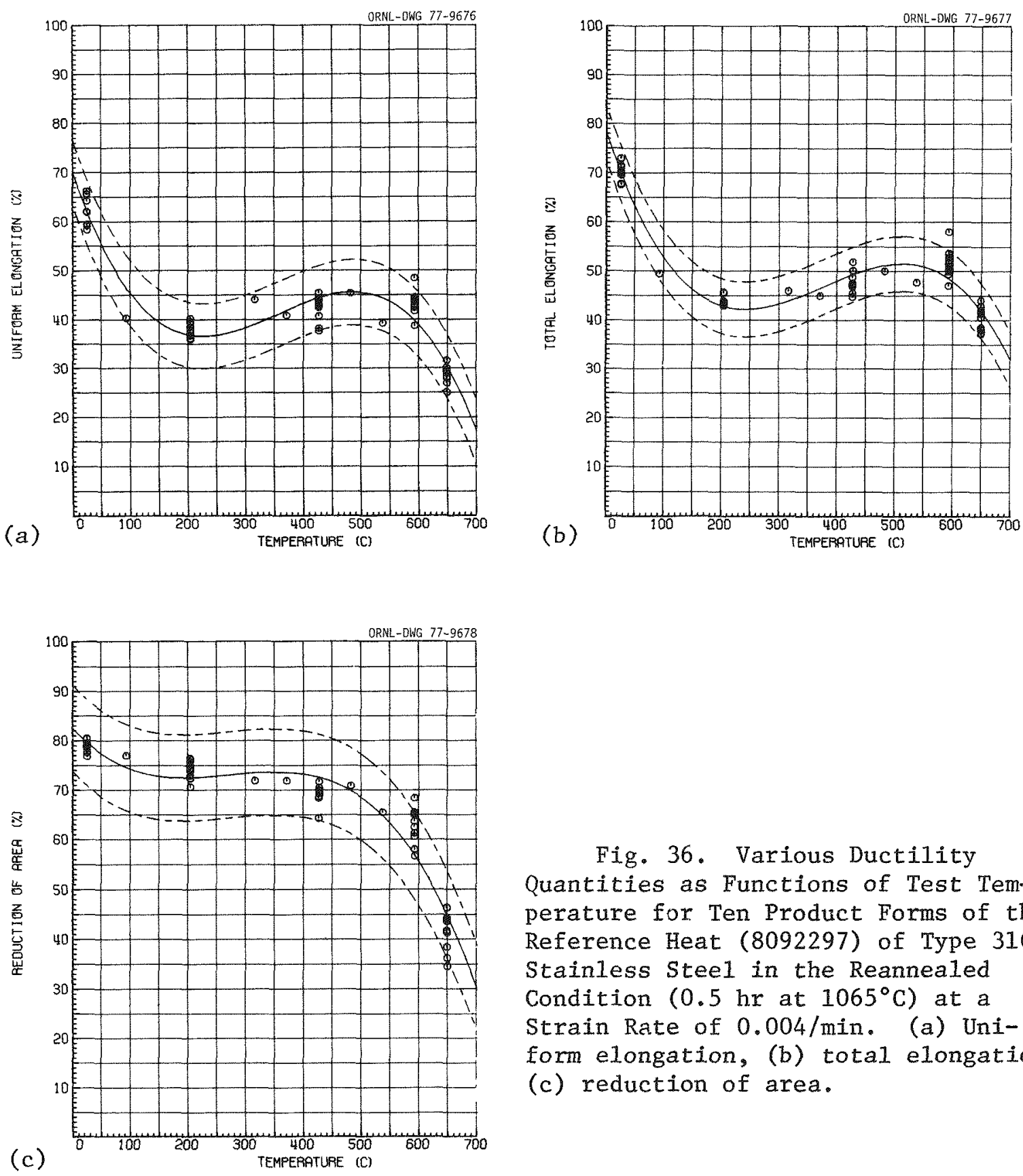

Fig. 36. Various Ductility Quantities as Functions of Test Temperature for Ten Product Forms of the Reference Heat (8092297) of Type 316 Stainless Steel in the Reannealed Condition $\left(0.5 \mathrm{hr}\right.$ at $\left.1065^{\circ} \mathrm{C}\right)$ at a Strain Rate of $0.004 / \mathrm{min}$. (a) Uniform elongation, (b) total elongation, (c) reduction of area. 
Table 10. Summary of Constants for Tensile Data Analysis on Plate, Bar, and Pipe of Reference Heat 8092297 of Type 316 Stainless Steel

\begin{tabular}{|c|c|c|c|c|c|c|c|}
\hline \multirow{2}{*}{ Condition } & \multirow{2}{*}{$\begin{array}{l}\text { Number of } \\
\text { Data Points }\end{array}$} & \multicolumn{4}{|c|}{ Regression Coefficients } & \multirow{2}{*}{ SEE } & \multirow{2}{*}{$\begin{array}{l}R^{2} \\
(\%)\end{array}$} \\
\hline & & $a_{0}$ & $a_{1}$ & $\alpha_{2}$ & $\alpha_{3}$ & & \\
\hline \multicolumn{8}{|c|}{$0.2 \%$ Yield Strength, MPa } \\
\hline Mil1 Annealed & 73 & 256.4 & -0.7390 & $1.662 \mathrm{E}-03$ & $-1.287 \quad E-06$ & 28.90 & 63.44 \\
\hline Reannealed & 55 & 225.6 & -0.6125 & $1.196 \mathrm{E}-03$ & $-8.540 \mathrm{E}-07$ & 11.63 & 92.71 \\
\hline \multicolumn{8}{|c|}{ U1timate Tensile Strength, MPa } \\
\hline Mill Annealed & 73 & 604.7 & -1.5267 & $5.267 \mathrm{E}-03$ & $-6.119 \mathrm{E}-06$ & 10.13 & 98.31 \\
\hline Reannealed & 55 & 599.7 & -1.4501 & $5.203 \mathrm{E}-03$ & $-5.631 \mathrm{E}-06$ & 10.69 & 98.52 \\
\hline \multicolumn{8}{|c|}{ Uniform Elongation, \% } \\
\hline Mill Annealed & 73 & 65.00 & -0.3289 & $1.107 \mathrm{E}-03$ & $-1.075 \mathrm{E}-06$ & 3.65 & 87.27 \\
\hline Reannealed & 55 & 69.74 & -0.3462 & $1.116 \mathrm{E}-03$ & $-1.042 \mathrm{E}-06$ & 3.34 & 90.89 \\
\hline \multicolumn{8}{|c|}{ Total Elongation, \% } \\
\hline Mi11 Annealed & 73 & 76.86 & -0.3351 & $9.989 \mathrm{E}-04$ & $-8.818 \quad E-07$ & 4.49 & 81.70 \\
\hline Reannealed & 55 & 77.86 & -0.3504 & $1.066 \mathrm{E}-03$ & $-9.414 \quad \mathrm{E}-07$ & 2.80 & 92.82 \\
\hline \multicolumn{8}{|c|}{ Reduction of Area, $\%$} \\
\hline Mill Annealed & 73 & 84.92 & -0.1403 & $4.995 E-04$ & $-5.398 \mathrm{E}-07$ & 4.30 & 89.50 \\
\hline Reannealed & 55 & 82.43 & -0.1266 & $5.038 E-04$ & $-6.128 \quad E-07$ & 4.36 & 89.39 \\
\hline
\end{tabular}


been shown to be more representative of experimental data than results from the ratio or the central tolerance method. The expected and lower bound values of each property are summarized in Table 11.

The room-temperature expected value of yield strength for ten reannealed product forms was $211 \mathrm{MPa}$. The SEE for these product forms was $11.63 \mathrm{MPa}$. Recently, we performed 24 room-temperature tensile tests on reannealed $16-\mathrm{mm}$ plate. The average yield strength from 24 tests was $214 \mathrm{MPa}$, with an SEE of $1 \mathrm{MPa}$. An SEE of $1 \mathrm{MPa}$ for 24 tests indicates that the reannealed material is microstructurally uniform and that the testing variation is minimal. The total variation in yield strength $(\mathrm{SEE}=11.6 \mathrm{MPa})$ of al1 product forms in reannealed condition is

Table 11. Summary of Expected and Minimum Values of Tensile Properties of Ten Product Forms of Reference Heat (8092297) of Type 316 Stainless Steel

\begin{tabular}{|c|c|c|c|c|c|c|c|c|c|c|}
\hline \multirow{2}{*}{$\begin{array}{c}\text { Test } \\
\text { Temperature } \\
\left({ }^{\circ} \mathrm{C}\right)\end{array}$} & \multicolumn{2}{|c|}{$0.2 \%$ Yield, MPa } & \multicolumn{2}{|c|}{$\begin{array}{l}\text { Ultimate Tensile } \\
\text { Strength, MPa }\end{array}$} & \multicolumn{2}{|c|}{$\begin{array}{l}\text { Uniform Elongation } \\
\qquad(\%)\end{array}$} & \multicolumn{2}{|c|}{$\begin{array}{c}\text { Total Elongation } \\
(\%)\end{array}$} & \multicolumn{2}{|c|}{$\underset{(\%)}{\text { Reduction of Area }}$} \\
\hline & Expected & Minimum ${ }^{a}$ & Expected & Minimum & Expected & Minimum & Expected & Minimum & Expected & Minimum \\
\hline \multicolumn{11}{|c|}{ As-Received Condition } \\
\hline 25 & 239 & 181 & 570 & 550 & 55 & 48 & 69 & 60 & 82 & 73 \\
\hline 50 & 223 & 165 & 542 & 522 & 51 & 44 & 62 & 53 & 79 & 70 \\
\hline 100 & 198 & 140 & 502 & 482 & 42 & 35 & 53 & 44 & 75 & 66 \\
\hline 150 & 179 & 121 & 482 & 462 & 37 & 30 & 46 & 37 & 73 & 64 \\
\hline 200 & 165 & 107 & 476 & 456 & 35 & 28 & 43 & 34 & 72 & 63 \\
\hline 250 & 155 & 97 & 479 & 459 & 35 & 28 & 42 & 33 & 72 & 63 \\
\hline 300 & 150 & 92 & 488 & 468 & 37 & 30 & 42 & 33 & 72 & 63 \\
\hline 350 & 146 & 88 & 497 & 477 & 39 & 32 & 44 & 35 & 72 & 63 \\
\hline 400 & 144 & 86 & 503 & 483 & 42 & 35 & 46 & 36 & 71 & 62 \\
\hline 450 & 143 & 85 & 500 & 480 & 43 & 36 & 48 & 38 & 69 & 60 \\
\hline 500 & 142 & 84 & 483 & 463 & 43 & 36 & 49 & 39 & 65 & 56 \\
\hline 550 & 139 & 81 & 449 & 429 & 40 & 33 & 48 & 38 & 60 & 51 \\
\hline 600 & 133 & 75 & 393 & 373 & 34 & 27 & 45 & 36 & 52 & 43 \\
\hline 650 & 1.25 & 67 & 309 & 289 & 24 & 17 & 39 & 30 & 42 & 33 \\
\hline \multicolumn{11}{|c|}{ Reannealed Condition } \\
\hline 25 & 211 & 187 & 567 & 546 & 62 & 55 & 70 & 64 & 80 & 71 \\
\hline 50 & 198 & 174 & 539 & 518 & 55 & 48 & 63 & 57 & 78 & 69 \\
\hline 100 & 175 & 151 & 501 & 480 & 45 & 38 & 53 & 47 & 75 & 66 \\
\hline 150 & 158 & 134 & 480 & 459 & 39 & 32 & 46 & 40 & 73 & 64 \\
\hline 200 & 144 & 120 & 473 & 452 & 37 & 30 & 43 & 37 & 73 & 64 \\
\hline 250 & 134 & 110 & 464 & 453 & 37 & 30 & 42 & 36 & 73 & 64 \\
\hline 300 & 126 & 102 & 481 & 460 & 38 & 31 & 43 & 37 & 74 & 65 \\
\hline 350 & 121 & 97 & 488 & 467 & 41 & 34 & 45 & 39 & 74 & 65 \\
\hline 400 & 117 & 93 & 492 & 471 & 43 & 36 & 48 & 42 & 74 & 65 \\
\hline 450 & 114 & 90 & 488 & 467 & 45 & 38 & 50 & 44 & 72 & 63 \\
\hline 500 & 112 & 88 & 472 & 451 & 45 & 38 & 52 & 46 & 69 & 60 \\
\hline 550 & 108 & 84 & 439 & 418 & 44 & 37 & 51 & 45 & 64 & 55 \\
\hline 600 & 104 & 80 & 386 & 365 & 39 & 32 & 48 & 42 & 56 & 47 \\
\hline 650 & 98 & 74 & 309 & 288 & 30 & 23 & 42 & 36 & 45 & 36 \\
\hline
\end{tabular}

${ }^{a}$ Minimum values $=$ expected -2 SEE. 
significantly greater than the variations observed with a single product form and testing variations ( $1 \mathrm{MPa}$ ). To help explain these differences, the experimental work described in the next section was performed on the effects of cold work on properties of post-cold-work-annealed 16-mm-plate.

Effect of the Amount of Cold Work on the Room-Temperature Tensile Properties after Subsequent Annealing

In this section we will show how room-temperature tensile properties of cold-worked-and-annealed specimens depend on the amount of cold work. We reannealed 24 as-received specimens from $16-\mathrm{mm}$ plate of the reference heat for $0.5 \mathrm{hr}$ at $1065^{\circ} \mathrm{C}$. Specimens in two sets were subjected to 12 different amounts of cold work (plastic strain) up to $30 \%$ in an Instron machine at a nominal strain rate of $0.004 / \mathrm{min}$. Tensile properties (proportional 1imit, $0.02 \%$ offset yield, $0.2 \%$ offset yield, stress at the end of plastic straining, and reduction of area) were obtained from extensometer traces, Instron load-time charts, and measurements on the specimens after straining. These data are summarized in Table 12.

of the specimens listed in Table 12, one set of 12 cold-worked specimens was annealed for $0.5 \mathrm{hr}$ at $1065^{\circ} \mathrm{C}$ and the other at $1150^{\circ} \mathrm{C}$. Then, the specimens were tensile tested at a nominal strain rate of $0.004 / \mathrm{min}$. The tensile data are summarized in Table 13. Various tensile properties of cold-worked-and-annealed specimens are plotted as a function of cold work in Figs. 37 and 38. These figures show the following:

1. Specimens cold worked and then annealed at $1065^{\circ} \mathrm{C}$ show an increase in the strength properties up to $4 \%$ cold work. Beyond $4 \%$ cold work the strength properties show a sharp drop. The $0.2 \%$ yield strength falls below the room-temperature minimum specified value of $207 \mathrm{MPa}$ at a cold work level of 5 to $6 \%$. The yield strength attains a minimum value of $197 \mathrm{MPa}$ at a cold-work level of $10 \%$. Beyond $10 \%$ cold work strength properties again show an increase, which levels off at cold-work levels of 15 to $30 \%$. In this region strengths become independent of cold work and even the annealing temperature after cold-working. 
Table 12. Tensile Data Taken During Cold Working Reannealed 16-mm Plate of Reference Heat (8092297) of Type 316 Stainless Steel. A11 specimens were annealed $0.5 \mathrm{hr}$ at $1065^{\circ} \mathrm{C}$ before cold working.

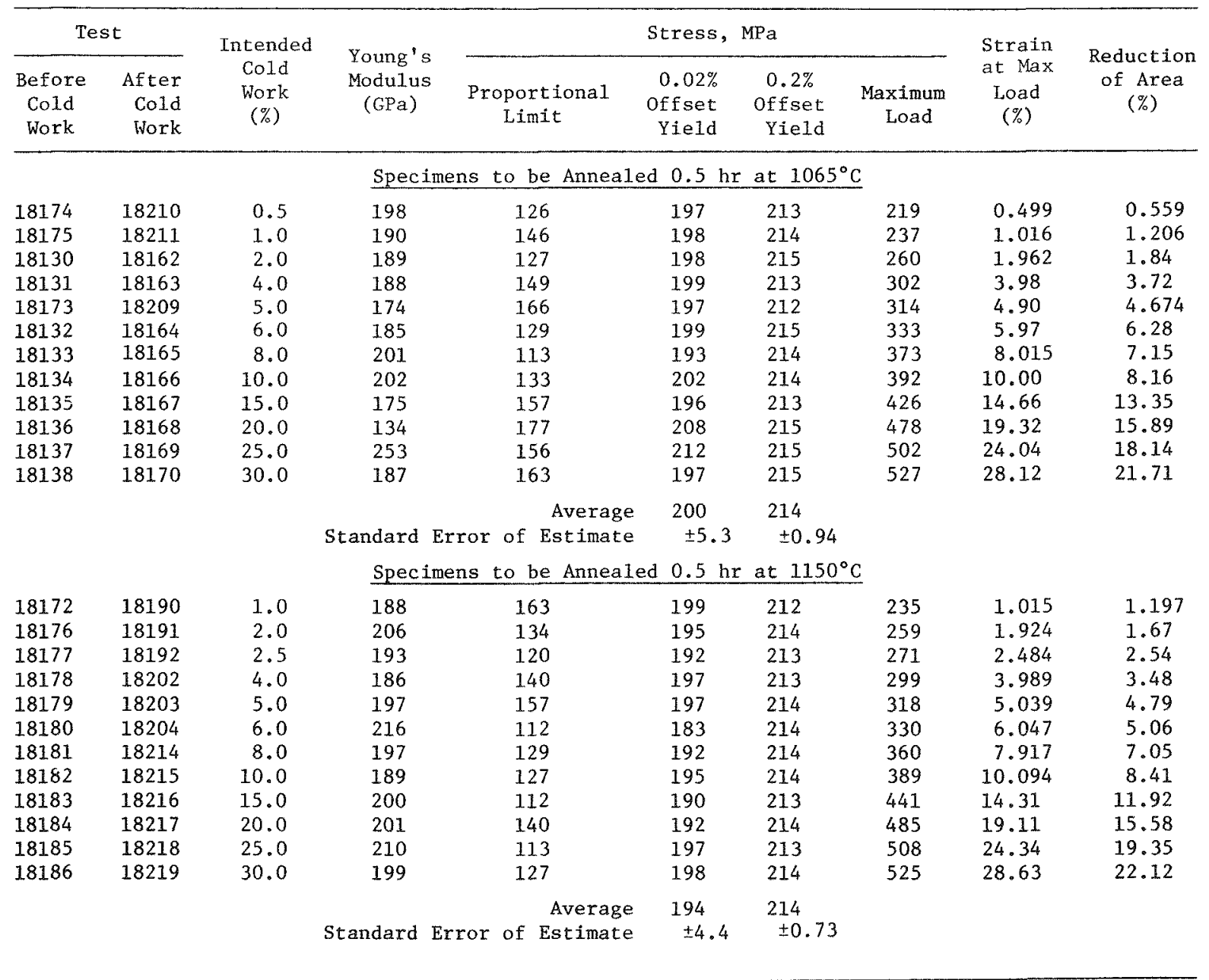

2. Specimens cold worked and then annealed at $1150^{\circ} \mathrm{C}$ showed a drop in strength properties for a cold-work less than $1 \%$. The yield strength again drops below the room-temperature minimum specified value and attains a value of approximately $190 \mathrm{MPa}$ for cold-work levels of 2 to $6 \%$. At higher cold-work levels the yield strength increases and approaches the values obtained for the $1065^{\circ} \mathrm{C}$ anneal at cold-work levels of $20 \%$ and greater.

3. Annealing at $1150^{\circ} \mathrm{C}$ after cold working did not show the initial hardening observed in yield strength for annealing at $1065^{\circ} \mathrm{C}$. 
Table 13. Tensile Data on Cold-Worked-and-Annealed 16-mm Plate of Reference Heat (8092297) of Type 316 Stainless Steel.

All specimens were annealed $0.5 \mathrm{hr}$ at $1065^{\circ} \mathrm{C}$ before cold working.

\begin{tabular}{|c|c|c|c|c|c|c|c|c|c|c|}
\hline \multicolumn{2}{|c|}{ Test } & \multirow{3}{*}{$\begin{array}{l}\text { Nominal } \\
\text { Cold } \\
\text { Work } \\
(\%)\end{array}$} & \multirow{3}{*}{$\begin{array}{l}\text { Young's } \\
\text { Modulus } \\
\text { (GPa) }\end{array}$} & \multicolumn{4}{|c|}{ Stress, MPa } & \multirow{2}{*}{\multicolumn{2}{|c|}{ Elongation, \% }} & \multirow{3}{*}{$\begin{array}{c}\text { Reduction } \\
\text { of Area } \\
(\%)\end{array}$} \\
\hline Before & After & & & \multirow{2}{*}{$\begin{array}{l}\text { Proportional } \\
\text { Limit }\end{array}$} & \multirow{2}{*}{$\begin{array}{r}0.02 \% \\
\text { Offset } \\
\text { Yield }\end{array}$} & \multirow{2}{*}{$\begin{array}{c}0.2 \% \\
\text { Offset } \\
\text { Yield }\end{array}$} & \multirow{2}{*}{$\begin{array}{l}\text { Ultimate } \\
\text { Tensile } \\
\text { Strength }\end{array}$} & & & \\
\hline $\begin{array}{l}\text { Cold } \\
\text { Work }\end{array}$ & $\begin{array}{l}\text { Cold } \\
\text { Work }\end{array}$ & & & & & & & Uniform & Total & \\
\hline \multicolumn{11}{|c|}{ Specimens Annealed $0.5 \mathrm{hr}$ at $1065^{\circ} \mathrm{C}$} \\
\hline 18174 & 18210 & 0.5 & 176 & 163 & 197 & 21.4 & 572 & 58.50 & 67.38 & 76.48 \\
\hline 18175 & 18211 & 1.0 & 183 & 159 & 209 & 225 & 583 & 59.55 & 70.30 & 79.26 \\
\hline 18130 & 18162 & 2.0 & 197 & 130 & 214 & 234 & 575 & 57.13 & 66.20 & 74.78 \\
\hline 18131 & 18163 & 4.0 & 198 & 131 & 226 & 251 & 578 & 57.12 & 68.25 & 78.00 \\
\hline 18173 & 18209 & 5.0 & 197 & 139 & 194 & 213 & 562 & 53.96 & 63.85 & 79.31 \\
\hline 18132 & 18164 & 6.0 & 204 & 107 & 187 & 202 & 561 & 61.32 & 71.86 & 78.88 \\
\hline 18133 & 18165 & 8.0 & 199 & 109 & 182 & 200 & 553 & 60.89 & 73.58 & 79.13 \\
\hline 18134 & 18166 & 10.0 & 192 & 135 & 190 & 197 & 537 & 62.24 & 71.05 & 78.06 \\
\hline 18135 & 18167 & 15.0 & 202 & 149 & 203 & 213 & 590 & 58.69 & 73.00 & 78.46 \\
\hline 18136 & 1.8168 & 20.0 & 203 & 104 & 197 & 207 & 560 & 57.38 & 67.58 & 77.78 \\
\hline 18137 & 18169 & 25.0 & 200 & 140 & 198 & 206 & 557 & 61.19 & 72.50 & 79.11 \\
\hline 18138 & 18170 & 30.0 & 194 & 144 & 203 & 211 & 565 & 55.11 & 67.90 & 78.40 \\
\hline \multicolumn{11}{|c|}{ Specimens Annealed $0.5 \mathrm{hr}$ at $1150^{\circ} \mathrm{C}$} \\
\hline 18358 & 18358 & 0.0 & 186 & 186 & 182 & 205 & 558 & 63.10 & 74.90 & 80.06 \\
\hline 18172 & 18190 & 1.0 & 196 & 140 & 187 & 203 & 550 & 58.54 & 68.75 & 78.18 \\
\hline 18176 & 18191 & 2.0 & 186 & 119 & 171 & 190 & 542 & 67.18 & 77.34 & 80.48 \\
\hline 18177 & 18192 & 2.5 & 203 & 103 & 171 & 191 & 546 & 65.14 & 76.58 & 79.14 \\
\hline 18178 & 18202 & 4.0 & 187 & 110 & 178 & 193 & 544 & 66.26 & 78.00 & 79.63 \\
\hline 18179 & 18203 & 5.0 & 197 & 105 & 171 & 195 & 549 & 66.24 & 75.75 & 80.03 \\
\hline 18180 & 18204 & 6.0 & 176 & 90 & 169 & 191 & 545 & 63.15 & 71.95 & 79.97 \\
\hline 18181 & 18214 & 8.0 & 1.83 & 126 & 181 & 198 & 557 & 63.92 & 73.70 & 79.37 \\
\hline 18182 & 18215 & 10.0 & 199 & 124 & 184 & 198 & 548 & 61.40 & 75.48 & 79.40 \\
\hline 18183 & 18216 & 15.0 & 184 & 137 & 189 & 201 & 553 & 60.08 & 71.10 & 78.58 \\
\hline 18184 & 18217 & 20.0 & 185 & 136 & 191 & 205 & 558 & 58.01 & 68.10 & 78.91 \\
\hline 18185 & 18218 & 25.0 & 195 & 126 & 197 & 204 & 561 & 57.07 & 69.65 & 79.17 \\
\hline 18186 & 18219 & 30.0 & 196 & 127 & 194 & 207 & 571 & 59.11 & 71.35 & 78.50 \\
\hline
\end{tabular}

4. Ductility quantities (uniform and total elongation and reduction of axea) decreased where strength properties showed an increase and increased where strength properties showed a decrease.

To describe the cold work effects, we have defined recovery of yield strength in the following manner:

$$
\text { Recovery }(\%)=\frac{S_{\max }-S_{y}}{S_{\max }-S_{y_{0}}} \times 100
$$

where

$$
\begin{aligned}
S_{\max } & =\text { flow stress at a given cold work (total strain) level, } \\
S_{y_{0}} & =0.2 \% \text { yield strength for annealed specimens, } \\
S_{y} & =0.2 \% \text { yield strength for cold-worked-and-annealed specimens. }
\end{aligned}
$$




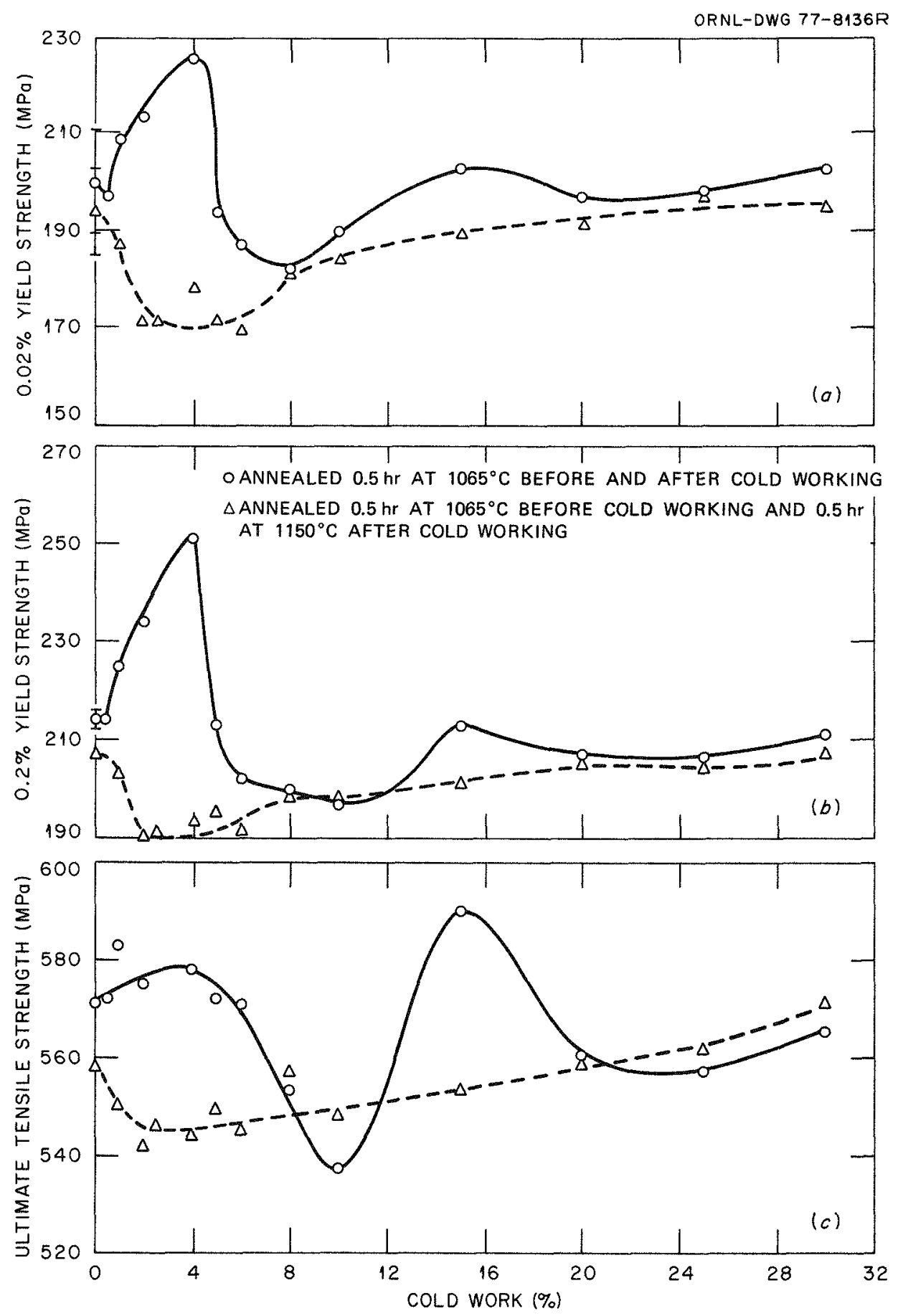

Fig. 37. Various Tensile Strength Properties as Functions of Cold Work for Cold-Worked-and-Annealed 16-mm P1ate of Reference Heat (8092297) of Type 316 Stainless Steel. All specimens were annealed for $0.5 \mathrm{hr}$ at $1065^{\circ} \mathrm{C}$ before cold working. One set of cold-worked specimens was annealed at $1065^{\circ} \mathrm{C}$ and the other at $1150^{\circ} \mathrm{C}$. (a) $0.02 \%$ yield strength. (b) $0.2 \%$ yield strength. (c) Ultimate tensile strength. 

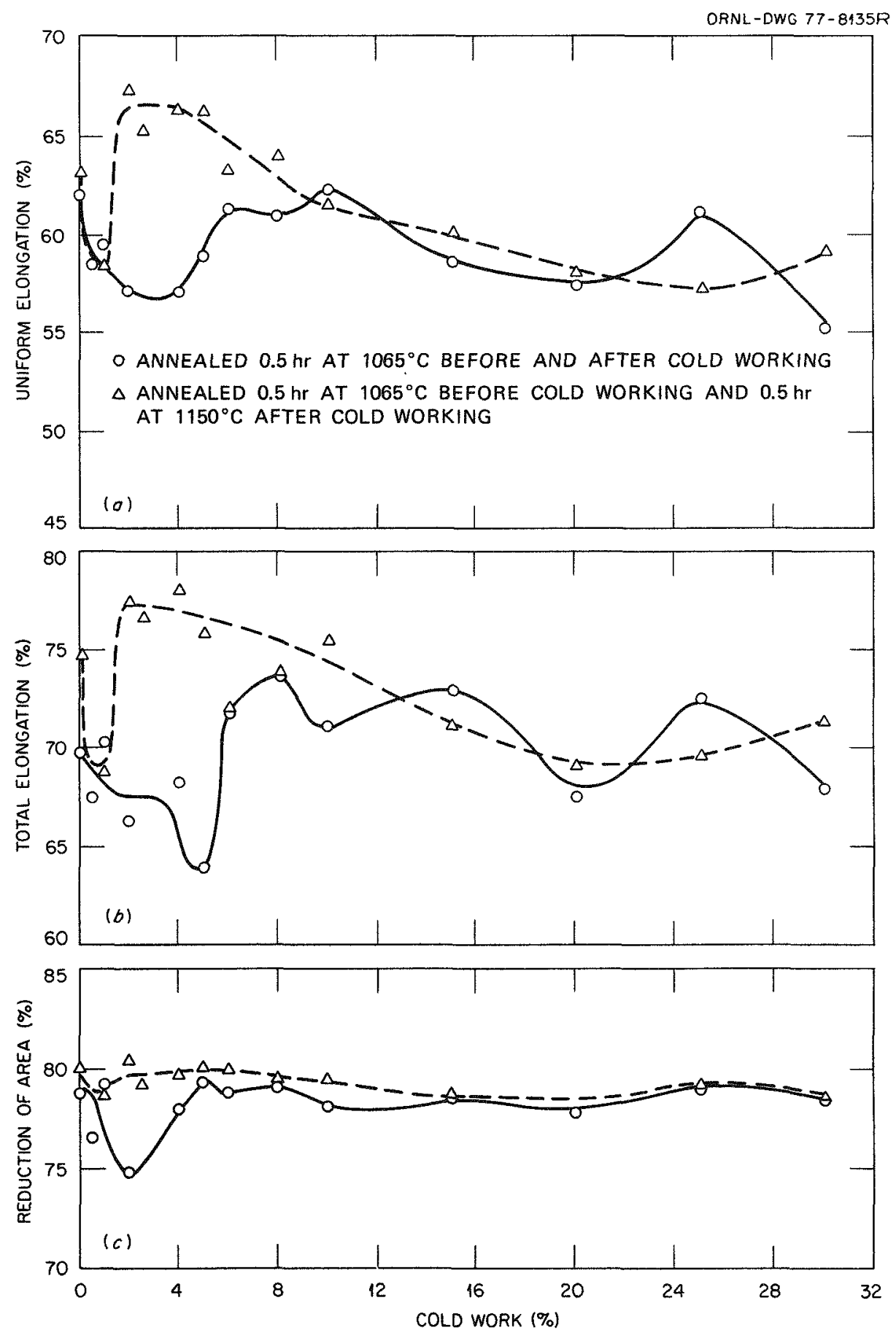

Fig. 38. Various Ductility Quantities as Functions of Cold Work for Cold-Worked-and-Annealed 16-mm Plate of Reference Heat (8092297) of Type 316 Stainless Steel. A.11 specimens were annealed for $0.5 \mathrm{hr}$ at $1065^{\circ} \mathrm{C}$ before cold working. One set of cold-worked specimens was annealed at $1065^{\circ} \mathrm{C}$ and the other at $1150^{\circ} \mathrm{C}$. (a) Uniform elongation. (b) Total elongation. (c) Reduction of area. 
The $S_{y_{0}}$ values for specimens cold worked and then annealed at $1150^{\circ} \mathrm{C}$ were obtained by reannealing an as-received specimen at $1065^{\circ} \mathrm{C}$ for $0.5 \mathrm{hr}$ and then again at $1150^{\circ} \mathrm{C}$ for $0.5 \mathrm{hr}$ and tensile testing at room temperature. This specimen served as a reference material for other specimens that were cold worked and then annealed at $1150^{\circ} \mathrm{C}$.

Recovery pexcent defined by $\mathrm{Eq}$. (9) is plotted as a function of cold work in Fig. 39. The recovery curves for both annealing temperatures start at $100 \%$ recovery for zero cold work. These curves for both annealing temperatures have been divided into regions. Regions for the $1065^{\circ} \mathrm{C}$

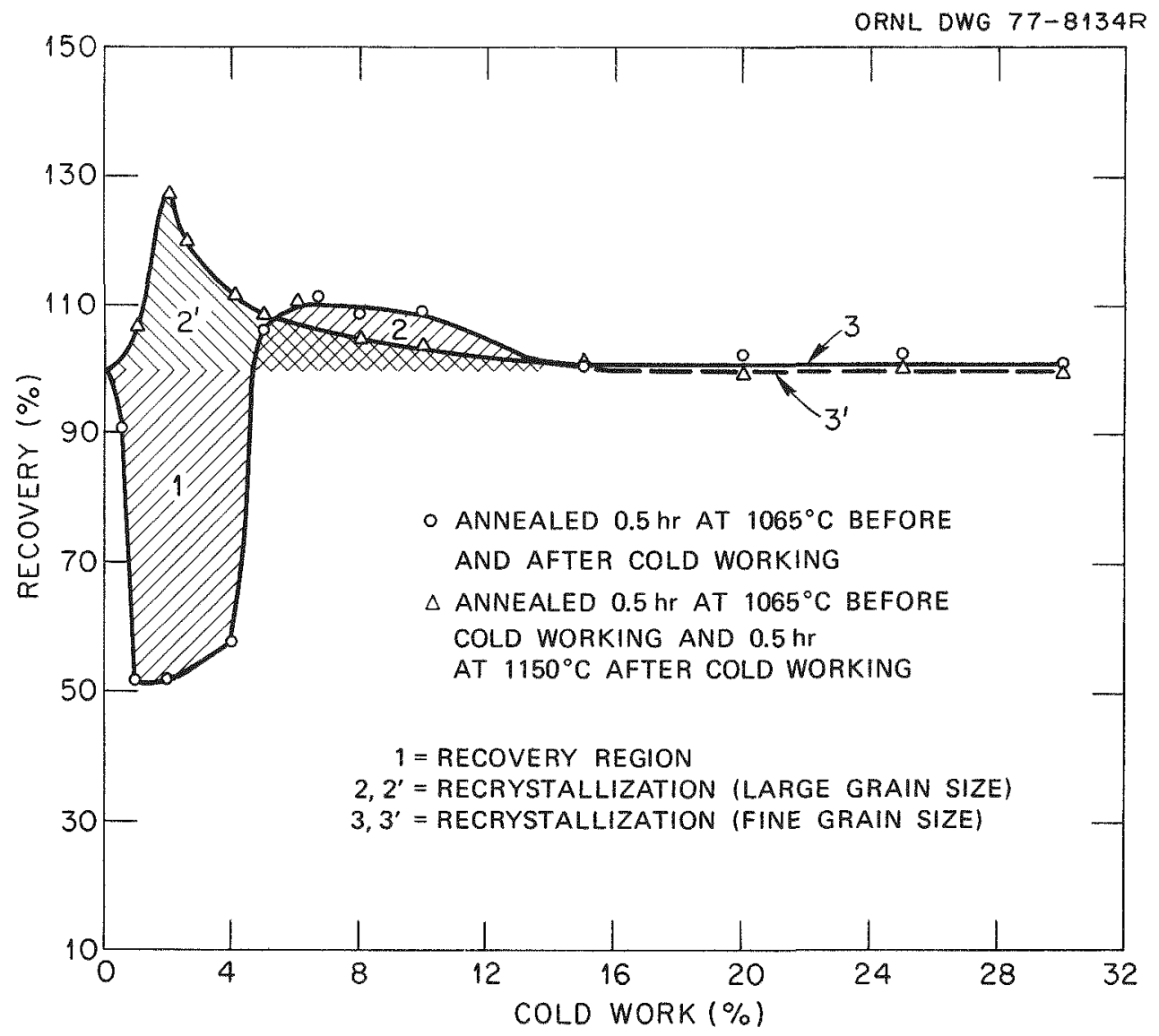

Fig. 39. Recovery as a Function of Cold Work for Cold-Worked-andAnnealed Specimens of the Reference Heat (8092297) of Type 316 Stainless Stee1. Regions 1, 2, and 3 are marked for annealing at $1065^{\circ} \mathrm{C}$ after cold-working, and the numbers with primes show the regions for annealing at $1150^{\circ} \mathrm{C}$. Region 1 is the recovery region. Regions 2 and $2^{\circ}$ show recrystallization with large grain size as end product. Regions 3 and $3^{-}$ show recrystallization with fine grain size as end product. 
anneal are marked by 1, 2, and 3, whereas regions for $1150^{\circ} \mathrm{C}$ anneal are marked by numbers with primes. The following optical microstructural observations were performed in an effort to explain various regions observed in Fig. 39.

1. Tensile tested specimens after various amounts of cold work and annealed at 1065 and $1150^{\circ} \mathrm{C}$ are shown in Figs. 40 and 41 . Note that tensile specimens annealed at $1065^{\circ} \mathrm{C}$ showed an orange peel effect at cold work levels of $5,6,8$, and $10 \%$, whereas specimens annealed at $1150^{\circ} \mathrm{C}$ showed orange peel effect at cold work levels of $2,2.5,4,5$, and $6 \%$. This effect reflects coarse grain structure.

2. Figures 42 through 48 show the optical microstructures in the unstressed and stressed regions of tensile tested specimens annealed at 1065 and $1150^{\circ} \mathrm{C}$ after cold work levels of $1,2,6,10,15,20$, and $30 \%$. The stressed microstructure shows elongated grains and also martensite formed during tensile testing. Grain size varied not only with cold work levels and annealing temperature, but also from specimen to specimen in the unstressed regions. Grain sizes (Table 14) were measured $^{15}$ for both unstressed and stressed regions. Since grain size in the unstressed region varied from specimen to specimen, a grain intercept ratio (GIR) was determined as a function of cold work. The GIR is given by:

$$
G I R=\frac{(\text { cold-worked plus reannealed) size }}{\text { (no cold work plus reannealed) size }}
$$

The no cold-work-plus-reannealed size represents microstructure in the buttonhead region of the tensile tested specimen. The grain size measurements in Table 14 did not include annealing-twin boundaries.

The GIR data from Table 14 are plotted against cold work in Fig. 49. We have marked a band of $1 \pm 0.2$ GIR as an error region due to grain size variations within the same specimen and to errors in measurement of grain size. This figure also shows two peaks in GIR for both annealing temperatures. 

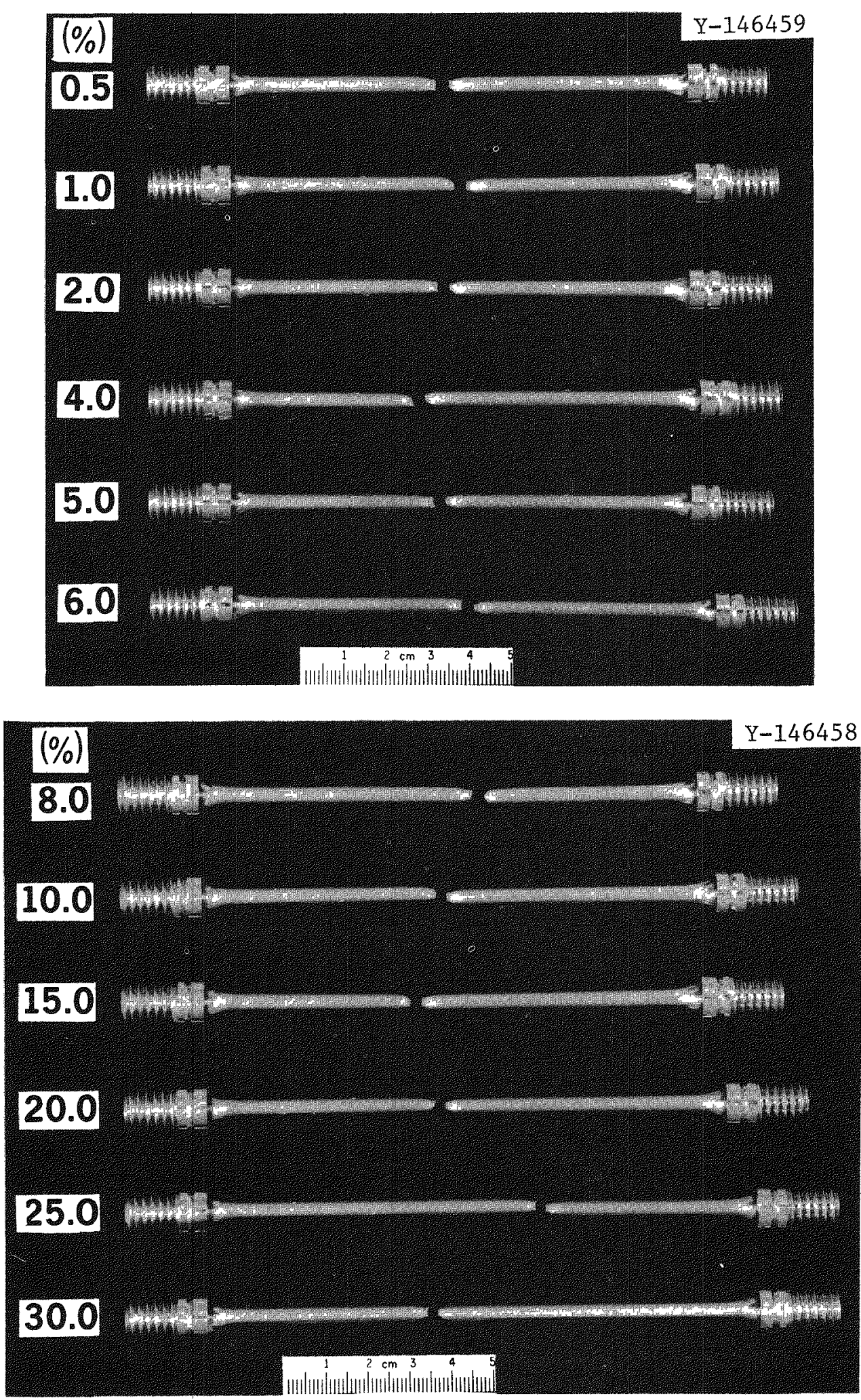

Fig. 40. Specimens of 16-mm Plate of the Reference Heat (8092297) of Type 316 Stainless Steel Cold-Worked the Indicated Percentages, Annealed $0.5 \mathrm{hr}$ at $1065^{\circ} \mathrm{C}$, and Tensile Tested. 

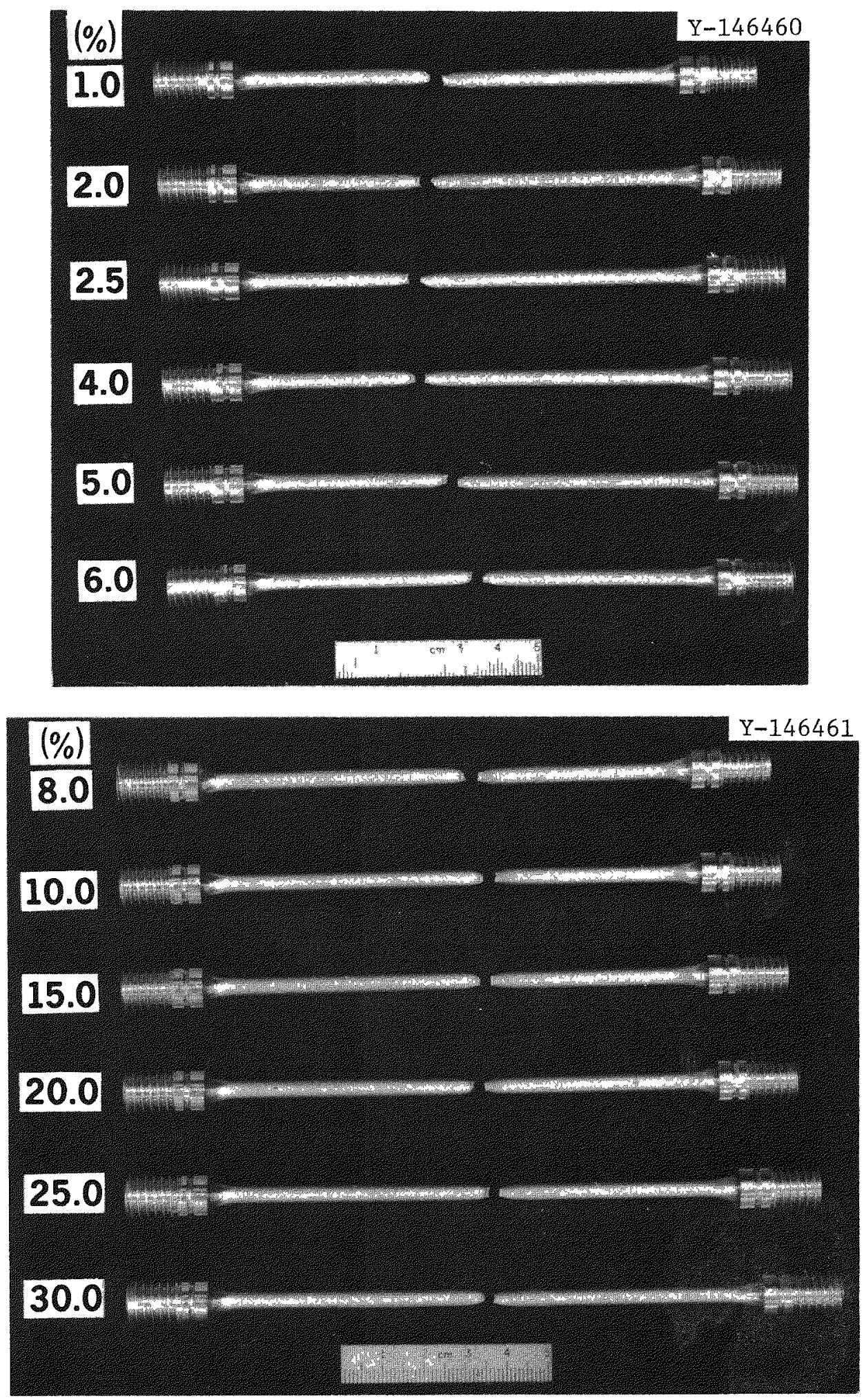

Fig. 41. Specimens of 16-mm Plate of the Reference Heat (8092297) of Type 316 Stainless Steel Cold-Worked the Indicated Percentages, Annealed $0.5 \mathrm{hr}$ at $1150^{\circ} \mathrm{C}$, and Tensile Tested. 

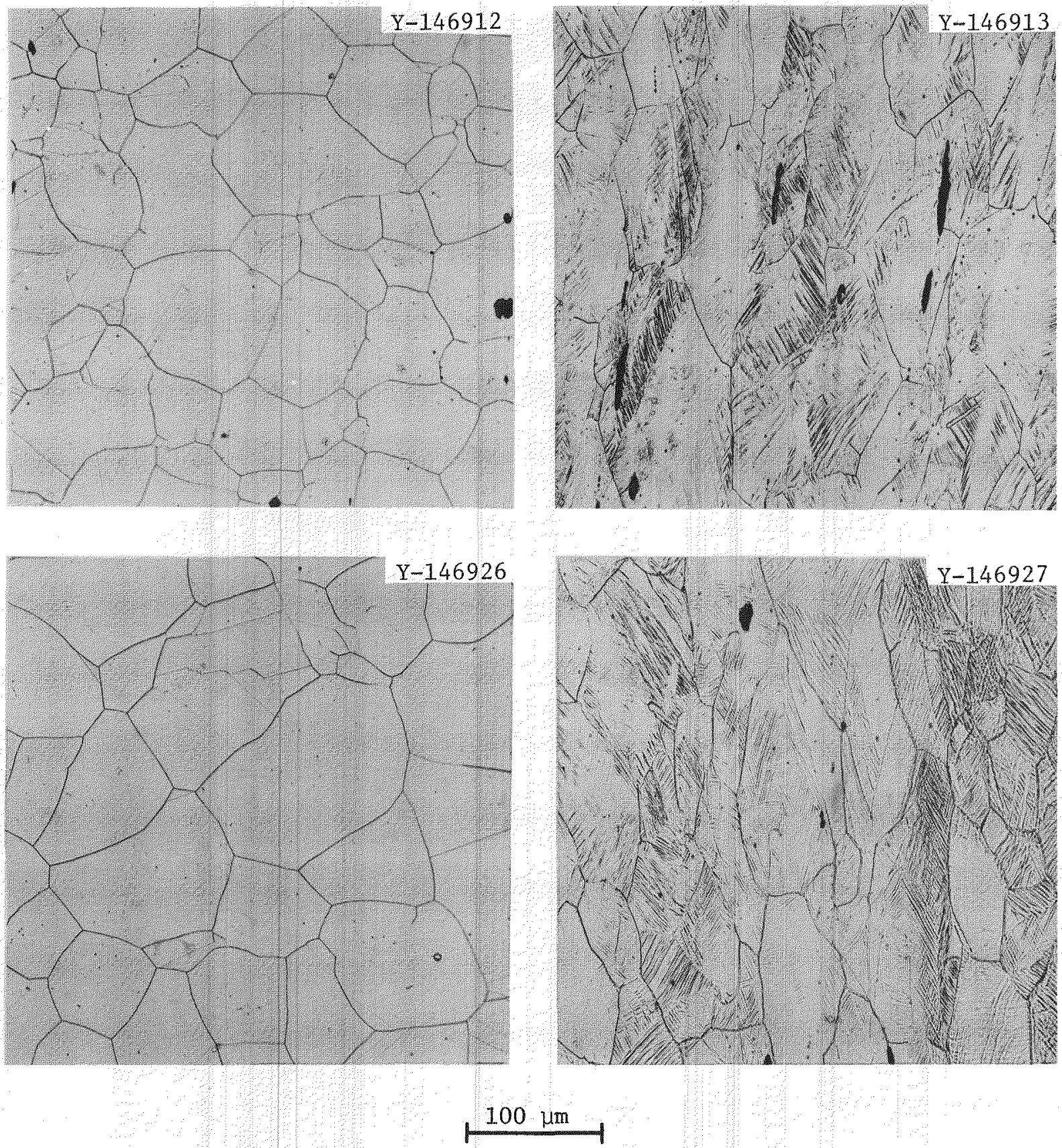

Fig: 42. Optical Microstructure of Unstressed (Left) and Stressed (Right) Regions of Tensile specimens of 16- $\mathrm{mm}$ Plate of the Reference Heat (8092297) of Type 316 Stainless Steel. Tensile specimens were cold-worked $1 \%$ and annealed for $0.5 \mathrm{hr}$ at 1065 (top) or $1150^{\circ} \mathrm{C}$ (bottom). 

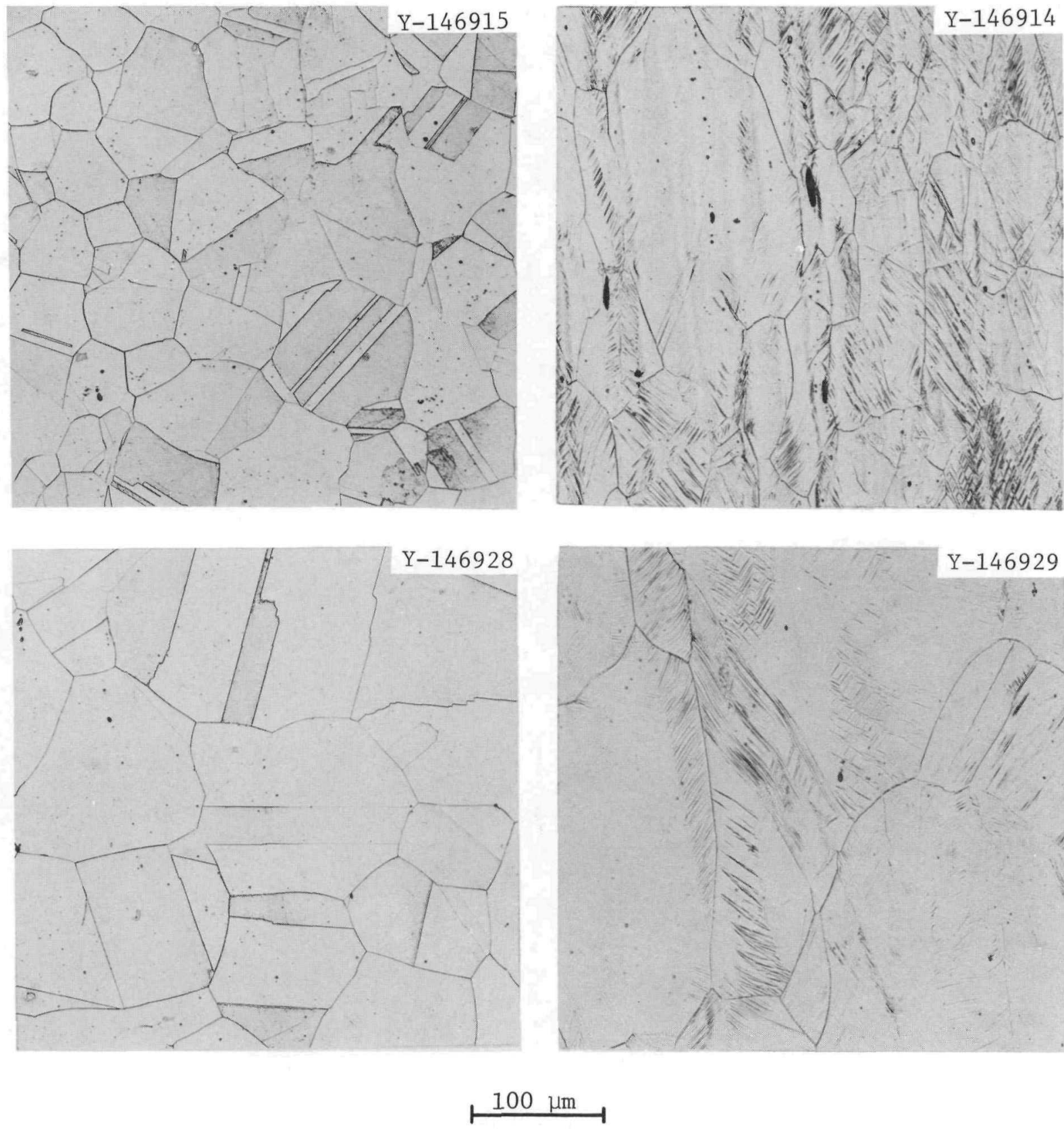

Fig. 43. Optical Microstructure of Unstressed (Left) and Stressed (Right) Regions of Tensile Specimens of 16-mm Plate of the Reference Heat (8092297) of Type 316 Stainless Steel. Tensile specimens were cold-worked $2 \%$ and annealed for $0.5 \mathrm{hr}$ at 1065 (top) or $1150^{\circ} \mathrm{C}$ (bottom). 

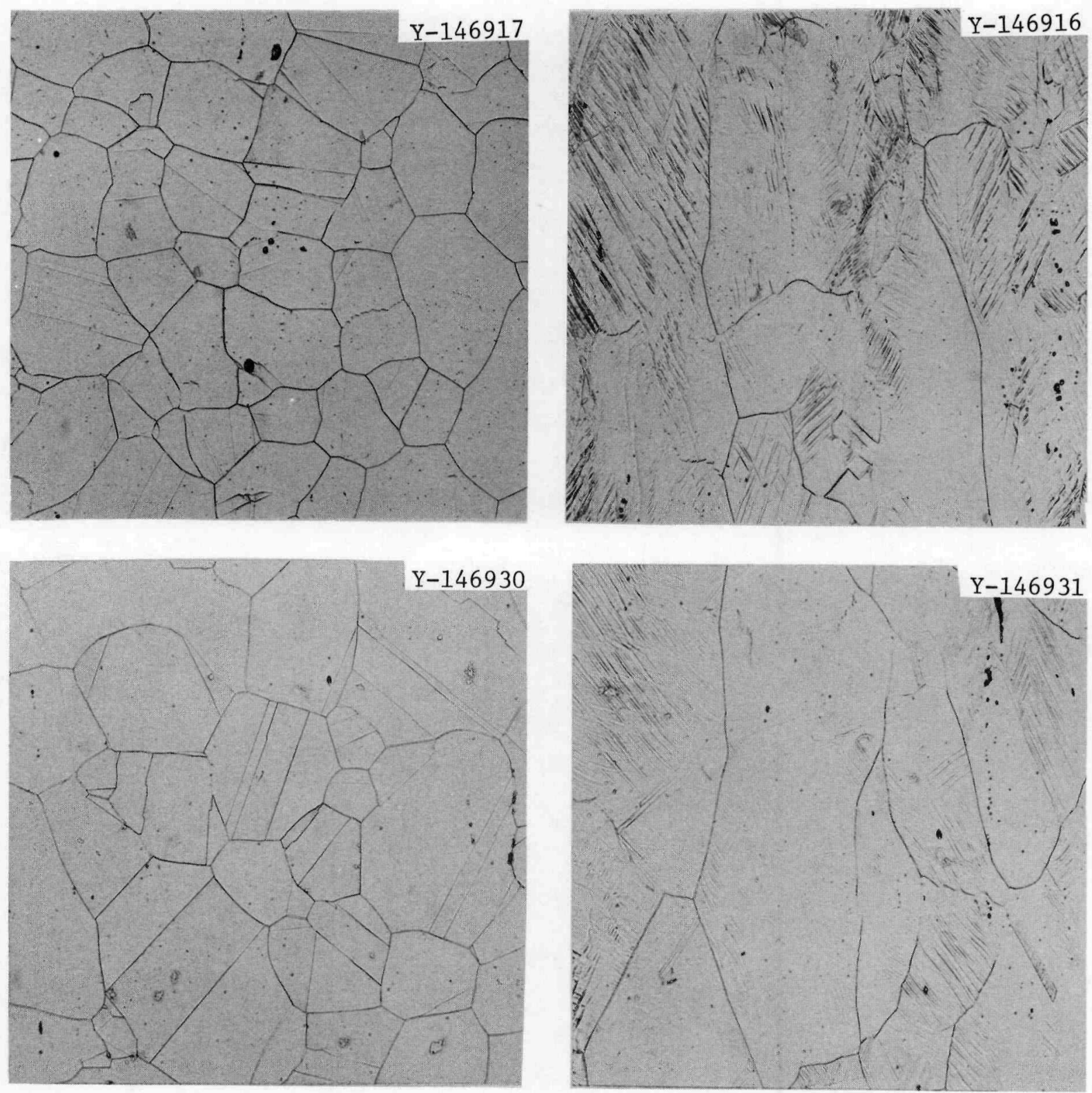

$100 \mu \mathrm{m}$

Fig. 44. Optical Microstructure of Unstressed (Left) and Stressed (Right) Regions of Tensile Specimens of 16-mm Plate of the Reference Heat (8092297) of Type 316 Stainless Steel. Tensile specimens were cold-worked $6 \%$ and annealed for $0.5 \mathrm{hr}$ at 1065 (top) and $1150^{\circ} \mathrm{C}$ (bottom). 

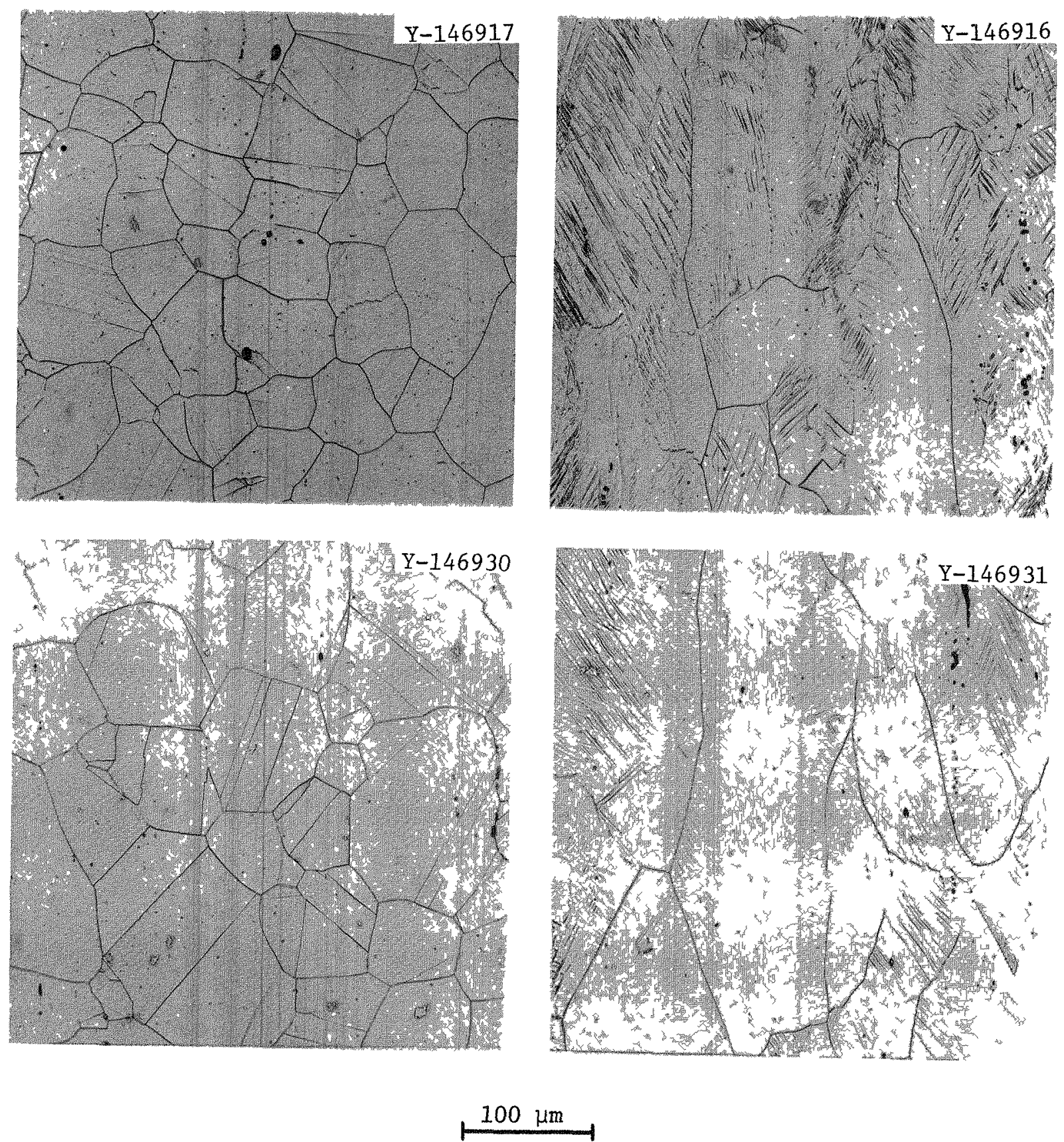

Fig. 44. Optical Microstructure of Unstressed (Left) and Stressed (Right) Regions of Tensile Specimens of 16-mm Plate of the Reference Heat (8092297) of Type 316 Stainless Steel. Tensile specimens were cold-worked $6 \%$ and annealed for $0.5 \mathrm{hr}$ at 1065 (top) and $1150^{\circ} \mathrm{C}$ (bottom). 

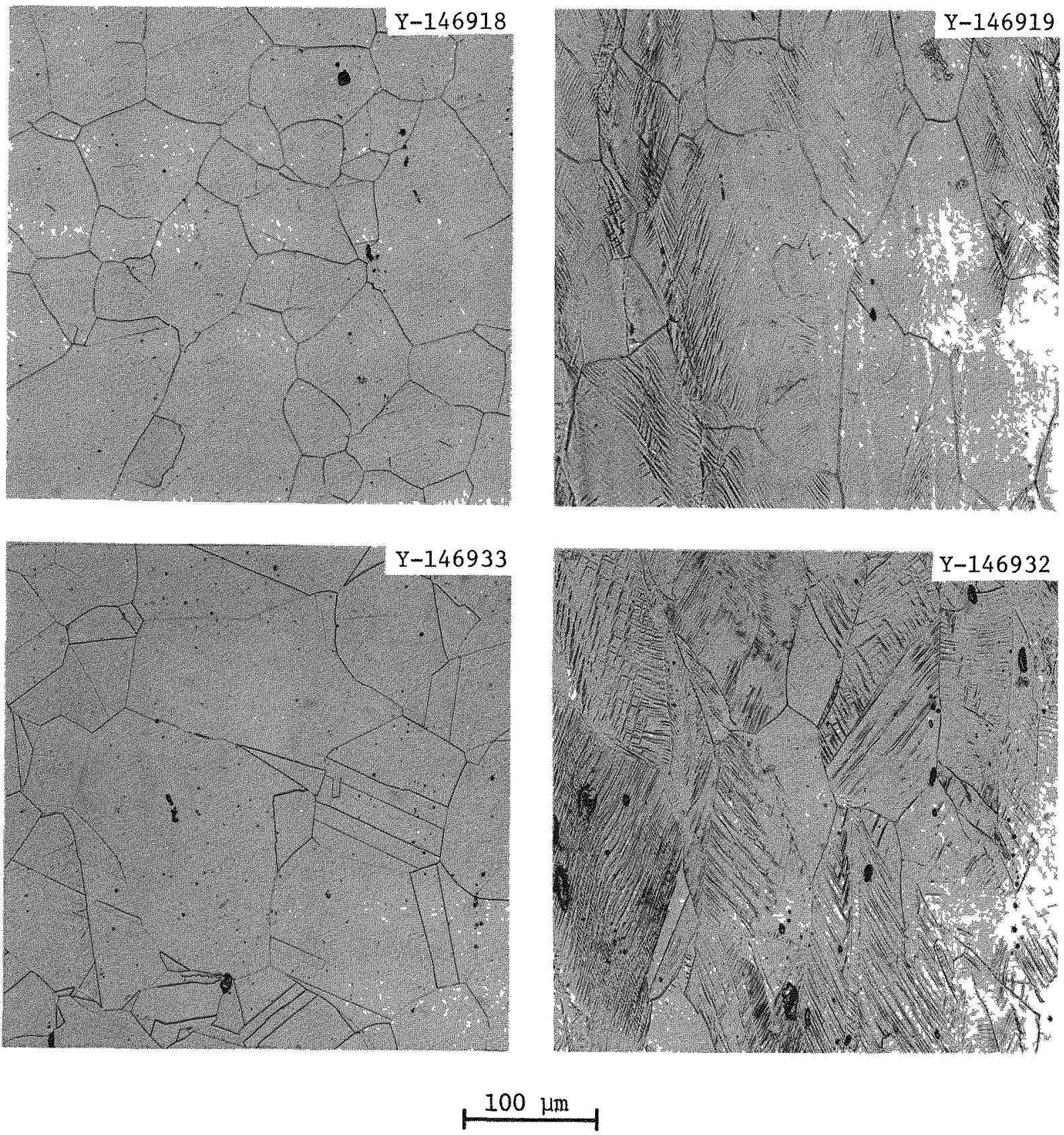

Fig. 45. Optical Microstructure of Unstressed (Left) and Stressed (Right) Regions of Tensile Specimens of 16-mm Plate of the Reference Heat (8092297) of Type 316 Stainless Steel. Tensile specimens were cold-worked $10 \%$ and annealed for $0.5 \mathrm{hr}$ at 1065 (top) or $1150^{\circ} \mathrm{C}$ (bottom). 

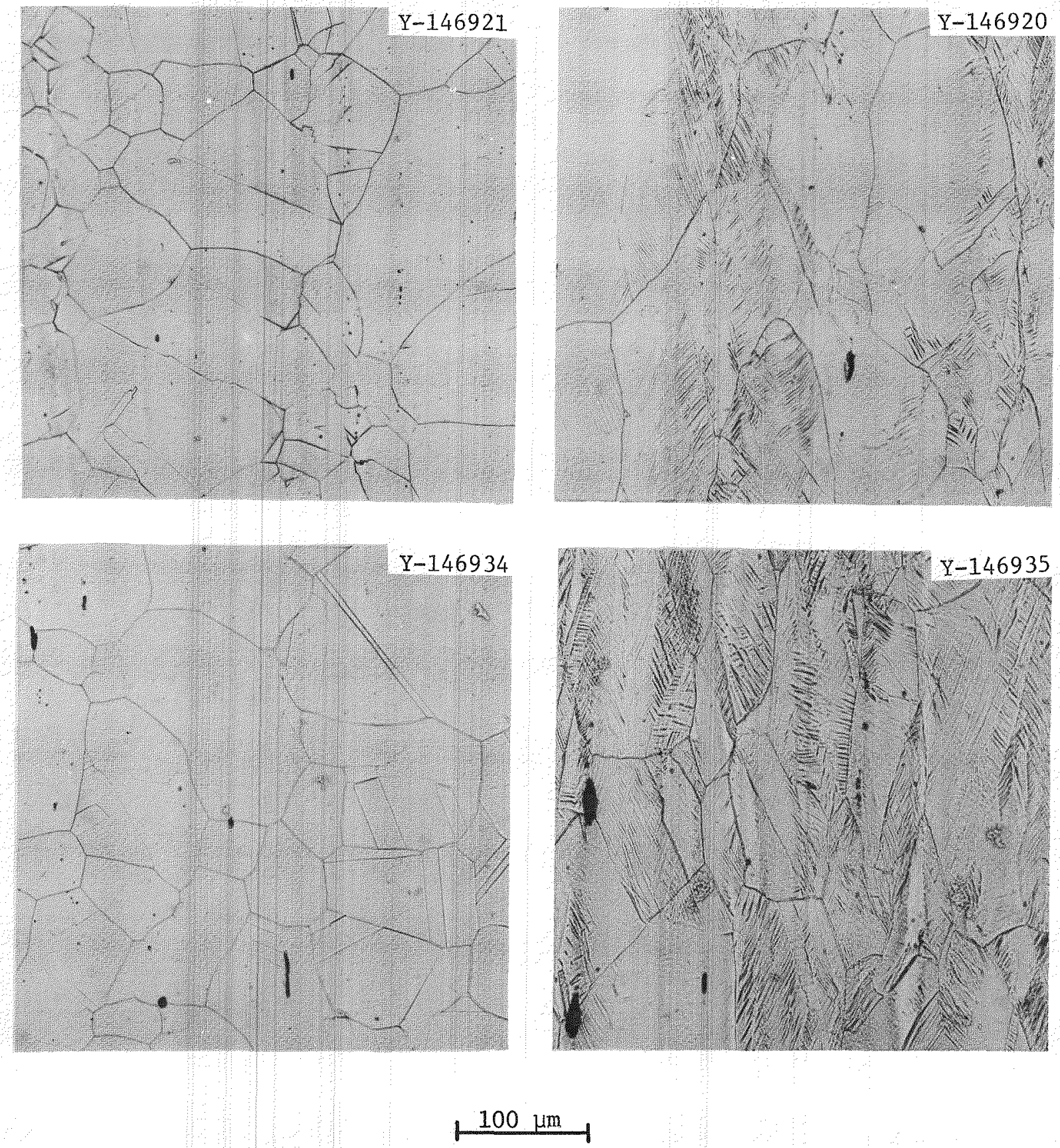

Fig. 46. Optical Microstructure of Unstressed (Left) and Stressed (Right) Regions of Tensile Specimens of 16- mm Plate of the Reference Heat (8092297) of Type 316 Stainless Steel. Tensile specimens were cold-worked $15 \%$ and annealed for $0.5 \mathrm{hr}$ at 1065 (top) or $1150^{\circ} \mathrm{C}$ (bottom). 

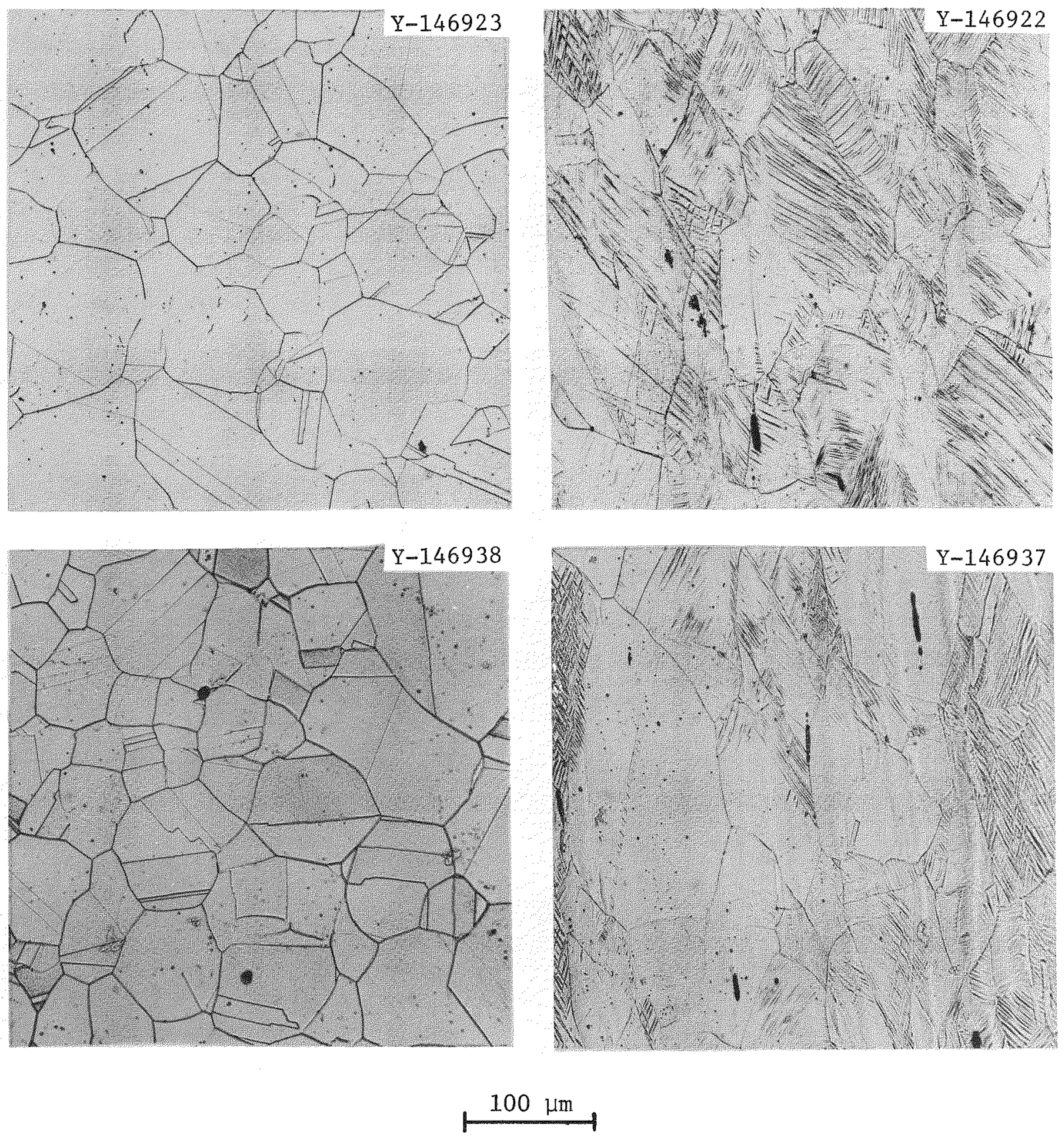

Fig. 47. Optical Microstructure of Unstressed (Left) and Stressed (Right) Regions of Tensile Specimens of $16-\mathrm{mm}$ Plate of the Reference Heat (8092297) of Type 316 Stainless Steel. Tensile specimens were cold-worked $20 \%$ and annealed for $0.5 \mathrm{hr}$ at 1065 (top) or $1150^{\circ} \mathrm{C}$ (bottom). 

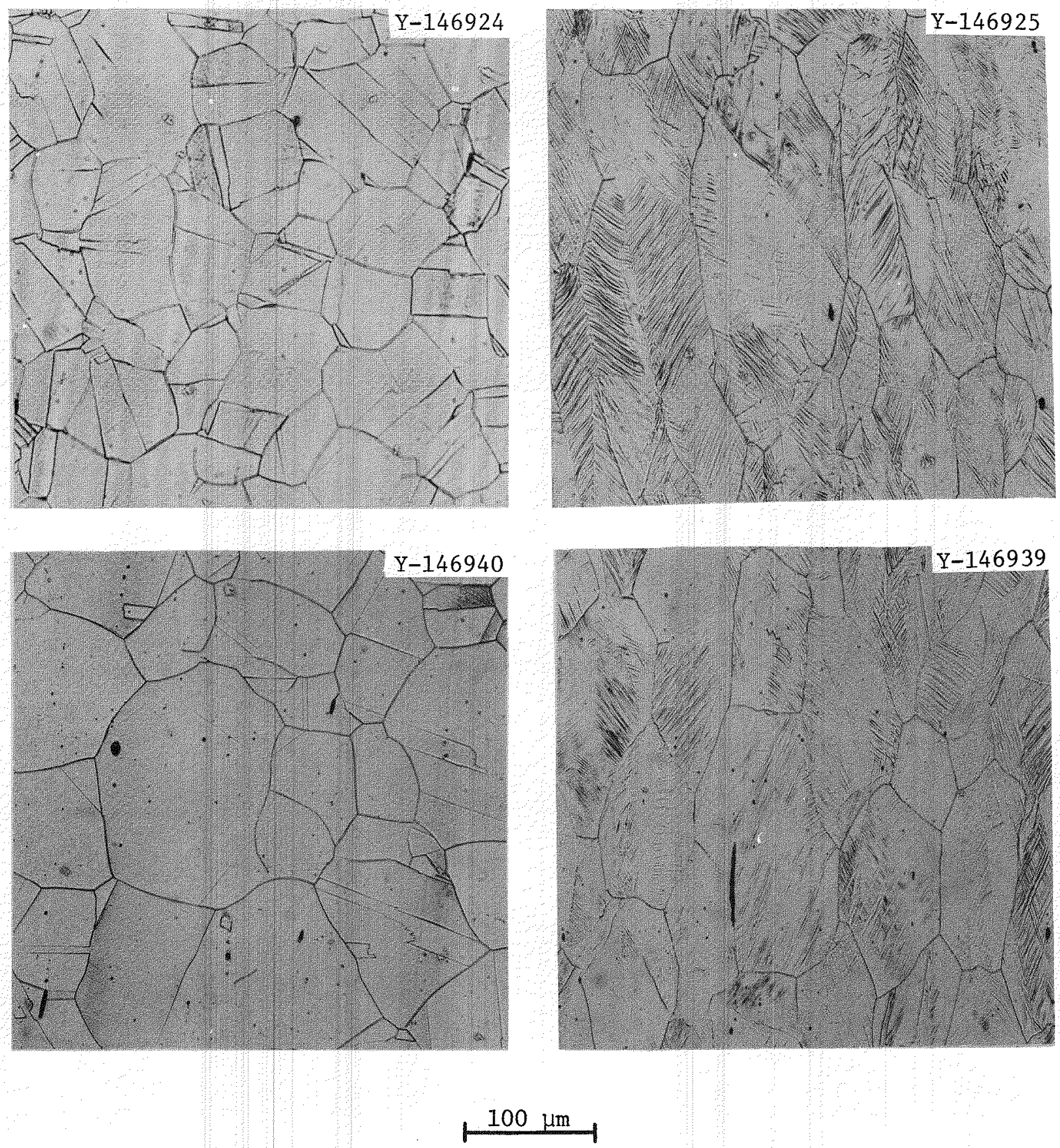

Fig. 48. Optical Microstructure of Unstressed (Left) and Stressed (Right) Regions of Tensile Specimens of 16-mm Plate of the Reference Heat (8092297) of Type 316 Stainless Steel. Tensile specimens were cold-worked $30 \%$ and annealed for $0.5 \mathrm{hr}$ at 1065 (top) and $1150^{\circ} \mathrm{C}$ (bottom). 
Table 14. Summary of Grain Sizes for Specimens Annealed after Various Amounts of Cold Work

\begin{tabular}{|c|c|c|c|c|c|c|}
\hline \multirow{3}{*}{$\begin{array}{c}\text { Cold } \\
\text { Work } \\
(\%)\end{array}$} & \multicolumn{4}{|c|}{ Grain Size, $\mu \mathrm{m}$ (ASTM) } & \multirow{2}{*}{\multicolumn{2}{|c|}{$\begin{array}{c}\text { GIR, Grain } \\
\text { Intercept Ratio }\end{array}$}} \\
\hline & \multicolumn{2}{|c|}{ Reannealed at $1065^{\circ} \mathrm{C}$} & \multicolumn{2}{|c|}{ Reannealed at $1150^{\circ} \mathrm{C}$} & & \\
\hline & Unstressed & Stressed & Unstressed & Stressed & $1065^{\circ} \mathrm{C}$ & $1150^{\circ} \mathrm{C}$ \\
\hline 1 & $51(5.2)$ & $57(4.9)$ & $76(4.1)$ & $56(4.9)$ & 1.11 & 0.74 \\
\hline 2 & $56(4.9)$ & $57(4.9)$ & $70(4.3)$ & $110(3.0)$ & 1.02 & 1.57 \\
\hline 6 & $64(4.6)$ & $103(3.2)$ & $76(4.1)$ & $110(3.0)$ & 1.61 & 1.45 \\
\hline 10 & $57(4.9)$ & $90(3.6)$ & $64(4.6)$ & $78(4.0)$ & 1.58 & 1.22 \\
\hline 15 & $73(4.2)$ & $108(3.1)$ & $70(4.3)$ & $76(4.1)$ & 1.48 & 1.09 \\
\hline 20 & $66(4.5)$ & $76(4.1)$ & $48(5.4)$ & $58(4.8)$ & 1.15 & 1.21 \\
\hline 30 & $46(5.5)$ & $56(4.9)$ & $70(4.3)$ & $62(4.7)$ & 1.22 & 0.89 \\
\hline
\end{tabular}

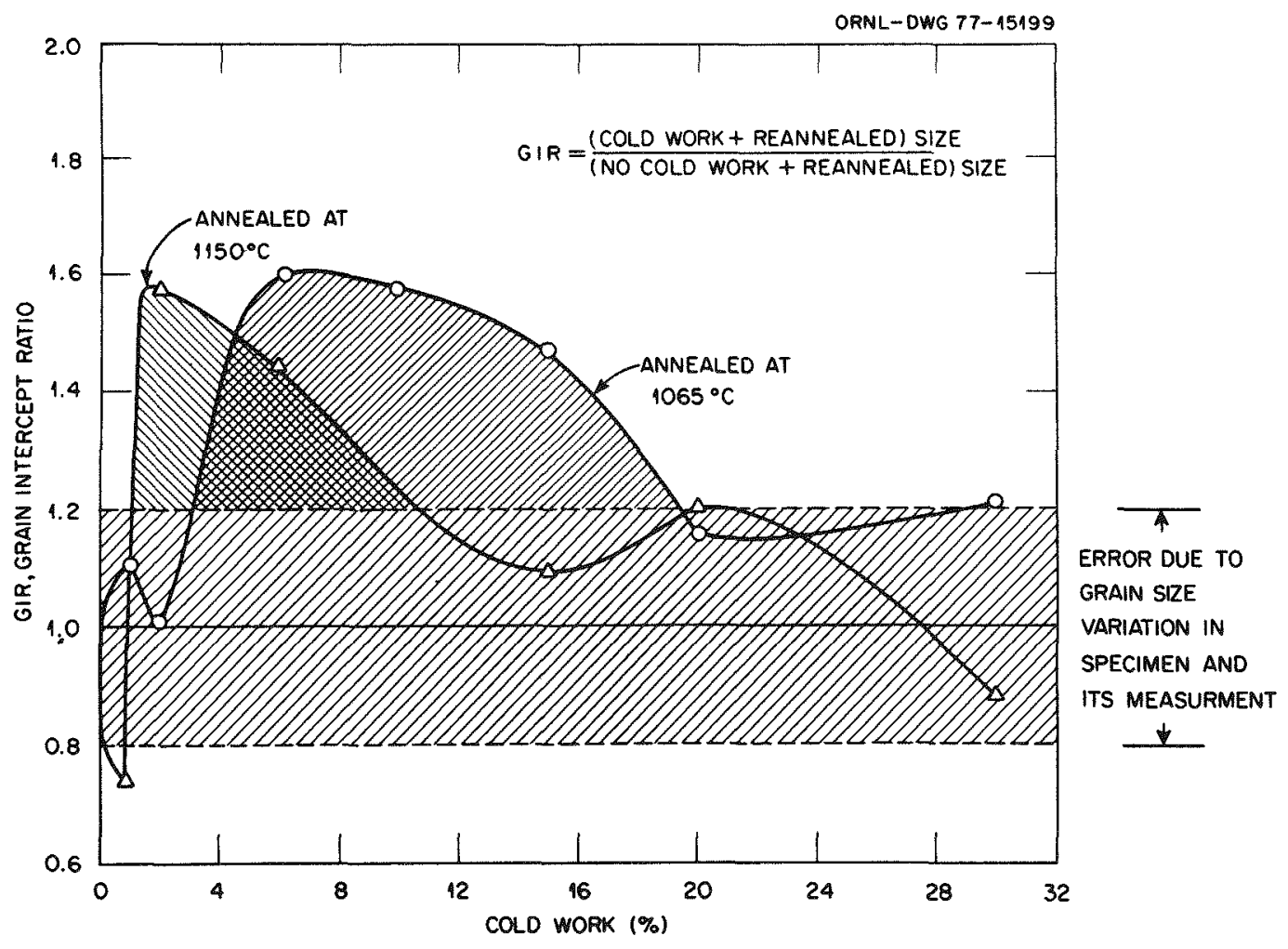

Fig. 49. Grain Intercept Ratio as a Function of Cold Work for ColdWorked-and-Annealed Tensile Specimens of 16-mm Plate of the Reference Heat (8092297) of Type 316 Stainless Stee1. 
The various regions in Fig. 39 can now be explained as follows:

Region 1 shows recovery. This region has recovery values of less than $100 \%$. The yield strength values in this region are higher than values after the first reanneal - before the cold work. This region is observed only for annealing at $1065^{\circ} \mathrm{C}$ after cold working and does not exist for the higher annealing temperature. The suggested recovery process in region 1 is supported by the essential lack of change in grain size in this region (Fig. 49).

Regions 2 and $2^{*}$ show recrystallization, with large grain size as the end product. This region is characterized by recovery values exceeding $100 \%$. The yield strength in this region is below the yield strength of reannealed material. The higher annealing temperature $\left(1150^{\circ} \mathrm{C}\right)$ has shifted the initiation of region $2^{\prime}$ to lower cold work values and has spread it over a wide range of cold work values as compared with region 2 observed for an annealing temperature of $1065^{\circ} \mathrm{C}$. The suggested recrystallization with large grain size as the end product is supported by the grain size peaks observed in Fig. 49.

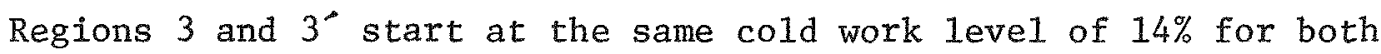
annealing temperatures. Recovery in these regions again shows values close to $100 \%$. These regions also represent recrystallization, but it produces a fine grain size as the end product. The cold-worked-andannealed yield strength in these regions is independent of both the amount of cold work and the annealing temperature. Furthermore, yield strength in these regions approaches the ASTM minimum specified value of $207 \mathrm{MPa}$.

The suggested recrystallization with fine grain size as end product in regions 3 and $3^{\circ}$ is again supported by the grain size observations presented in Fig. 49.

The yield strength data for the recrystallized regions are plotted as a function of $d^{-1 / 2}$ in Fig. 50. Included is the line fitted to yield strength data for various reannealed product forms in Fig. 32. We have also included in this figure the line determined from the following relationship observed for seven different reannealed heats: 


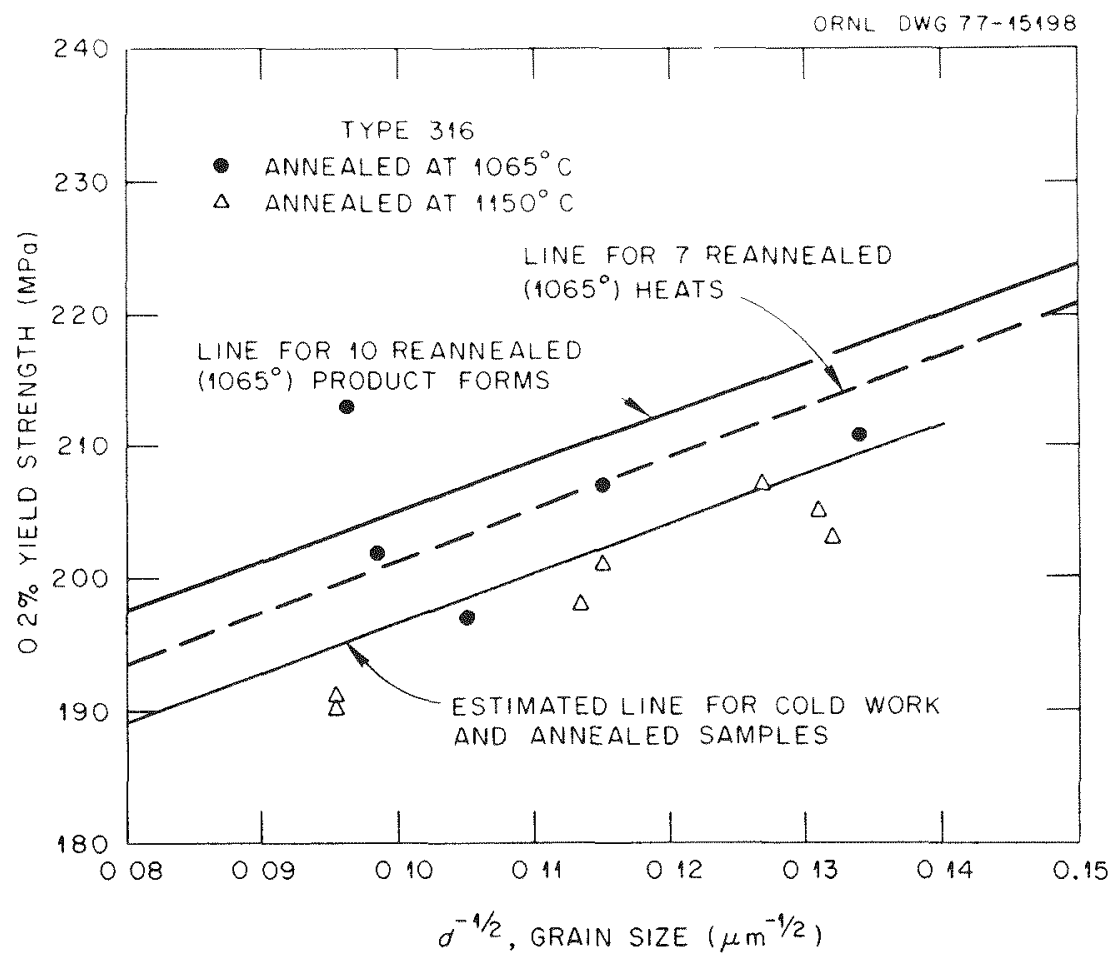

Fig. 50. The 0.2\% Yield Strength as a Function of Grain Size for Cold-Worked-and-Annealed Tensile Specimens of 16-mm Plate of the Reference Heat (8092297) of Type 316 Stainless Steel.

$$
S_{y}=S_{0}+B(C+N) d^{-1 / 2}
$$

where $S_{0}$ and $B$ are constants with room-temperature values of 162 and 4286, respectively, for $S_{y}$ in $\mathrm{MPa}$, carbon $(C)$ and nitrogen $(N)$ in wt $(\%)$, and grain size (d) in $\mu \mathrm{m}$. For comparison, we have drawn an estimated line of slope shown in Fig. 32 through the data on cold-worked-andannealed specimens. The following points are to be noted from Fig. 50 .

1. Lines determined from data on ten different product forms of a single heat (8092297) agree reasonably well with the line determined from data on seven different heats.

2. Data on cold-worked-and-annealed specimens show a slope similar to that shown by ten different product forms or seven different heats. However, the data fall 8.5 and $4.5 \mathrm{MPa}$ ( 1.23 and $0.65 \mathrm{ksi}$ ), respectively, below the two lines.

3. The changes observed in yield strength for regions $2,2^{-}$and $3,3^{-}$of Fig. 39 are indeed a consequence of corresponding changes in 
grain size in these regions by recrystallization and grain growth. However, a difference of $8.5 \mathrm{MPa}(1.23 \mathrm{ksi})$ between the results obtained from various product forms and the data from cold-worked-and-annealed specimens need explanation. In our opinion, the shift in the estimated line to the right of that observed for ten different product forms (which gives lower values) is caused by the following two reasons:

a. The grain size measured from elongated grains of stressed region is most likely to give smaller values (from geometric considerations) as compared with equiaxed grains. The correction factors to correct for elongated grains will depend on grain size and thus require an extensive test program for their determination. However, it is to be noted that the correction factor yielding higher grain size values will shift the estimated line towards the line for ten different product forms.

b. The martensite present in the deformed elongated grains introduced additional problems in measuring the grain size. Since martensite feathers could be confused with grain boundaries, the measured grain size is possibly again smaller than the actual size. Correction for errors due to martensite will also shift the estimated line in the correct direction.

From what has been said above, one can state that the changes in yield strength in regions marked as recrystallized in Fig. 39, are indeed a result of grain size changes, although the exact position of the estimated line is shifted because of errors described above in measuring grain sizes.

Use of the Properties of Cold-Worked-and-Annealed Specimens to Explain Variations in Tensile Properties of Various Product Forms

Results presented in Table 9 showed that the residual cold work in various product forms can vary from 2 to $6.5 \%$. Furthermore, the residual cold work for 51 - and $64-\mathrm{mm}$ bars (Fig. 11) varied from the center to the outside. The reannealing of various product forms involves the same steps 
as are involved in cold-working and annealing. That is, the final step in manufacturing various products is solution annealing. The solution annealed products are subjected to straightening and sizing, which introduce varying amounts of cold work into these products. These products were reannealed $0.5 \mathrm{hr}$ at $1065^{\circ} \mathrm{C}$ at ORNL. Thus, the reannealed material should be quite similar to the cold-worked-and-annealed material. The data for cold-worked-and-annealed material in Fig. 37(b) show that a variation in cold work of 0 to $14 \%$ can change the yield strength by approximately $40 \mathrm{MPa}$. The SEE of $11 \mathrm{MPa}$ observed for all products minus $1 \mathrm{MPa}$ observed for 24 tests on 16-mm plate gives a net variation of $10 \mathrm{MPa}$. Previous work $\mathrm{k}^{18,19}$ and results plotted in Figs. 33 through 36 show that the total variations in experimental data are described by $\pm 2 \mathrm{SEE}$ about the expected value. Thus, an SEE of $10 \mathrm{MPa}$ corresponds to approximately $40 \mathrm{MPa}$ of variation in yield strength of these product forms, which is in excellent agreement with the cold-worked-and-annealed properties in Fig. $37(\mathrm{~b})$.

The ultimate tensile strength for reannealed product form showed an SEE of $10.69 \mathrm{MPa}$ (Table 10), which gives a total variation close to $43 \mathrm{MPa}$. Such a variation again agrees excellently with the data in Fig. 37 (c) and Table 13 on cold-worked-and-annealed material. The uniform elongation for all reannealed products showed an SEE of $3.34 \%$ or a total variation of ( $₫ 2 \mathrm{SEE}) 13 \%$. Such a variation also agrees reasonably well with the results of Fig. 38(a) and Table 13 on coldworked-and-annealed material. Total variations in total elongation and reduction of area of all product forms can also be explained by the data for cold-worked-and-annealed material.

Thus, we can conclude that the product form variations observed in the reannealed data for this single heat are related to the effect of varying amount of cold work on recovery and recrystallization processes.

\section{Comparison of Expected and Minimum Properties}

The expected and minimum (expected minus 2SEE) values of yield and ultimate tensile strength from Table 11 are plotted in Fig. 51 for both as-received and reannealed material. Similar values for uniform and 

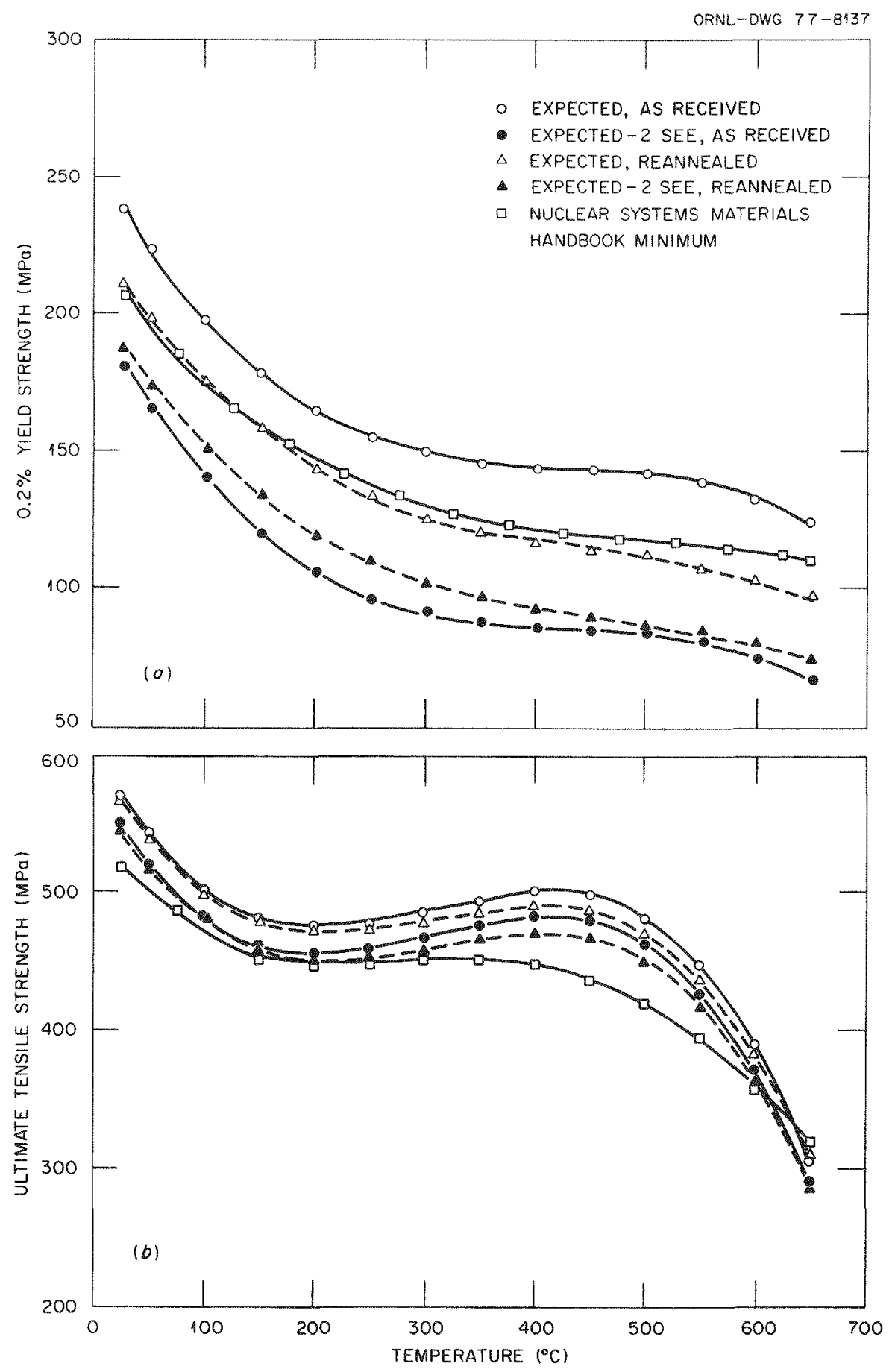

Fig. 51. Expected and Minimum Values (Expected Minus 2SEE) of Yield and Ultimate Tensile Strength as a Function of Test Temperature for Ten Product Forms of the Reference Heat (8092297) of Type 316 Stainless Steel. Nuclear Systems Materials Handbook minimum values are also included in these plots. (a) Yield strength. (b) ritimate tensile strength. 
total elongation and reduction of area are plotted in Fig. 52. These figures also include the Nuclear Systems Materials Handbook (NSMH) minimum values. The following comments can be made from these figures. Yield Strength - The expected value curve for reannealed product forms falls approximately $29 \mathrm{MPa}$ below the as-received expected values. Because of significantly higher variation in as-received data, the reannealed minimum values are slightly above the as-received minimum values. The NSMH minimum value curve is significantly higher than the as-received minimum defined as expected minus 2SEE. Furthermore, the NSMH minimum curve lies for most of the temperature range above the reannealed average. This is consistent with previously reported ${ }^{18,19}$ work on type 304 stainless stee1.

Ultimate Tensile Strength - The expected and minimum value curves for ultimate tensile strength were quite close for both as-received and reannealed product forms. The NSMH minimum value curve agreed with the ORNL minimum curve for test temperatures below $600^{\circ} \mathrm{C}$. At higher temperatures the NSMH minimum value curve crosses over the expected value curve. Ductility Quantities - The expected and minimum value curves for all three ductility quantities (uniform elongation, total elongation, and reduction of area) in the reannealed condition were slightly above the as-received curves. The NSMH minimum value curves were well below the ORNL minimum curves for both the uniform and total elongation. There is no minimum value curve for reduction of area in the NSMH.

\section{Stress-Strain Behavior (Up to $4 \%$ Strain)}

The monotonic stress-strain behavior (up to $4 \%$ strain) of austenitic stainless steel can be described by:

$$
\sigma-\sigma_{P L}=\frac{C P e_{p}}{1+P e_{p}}+H e_{p}
$$



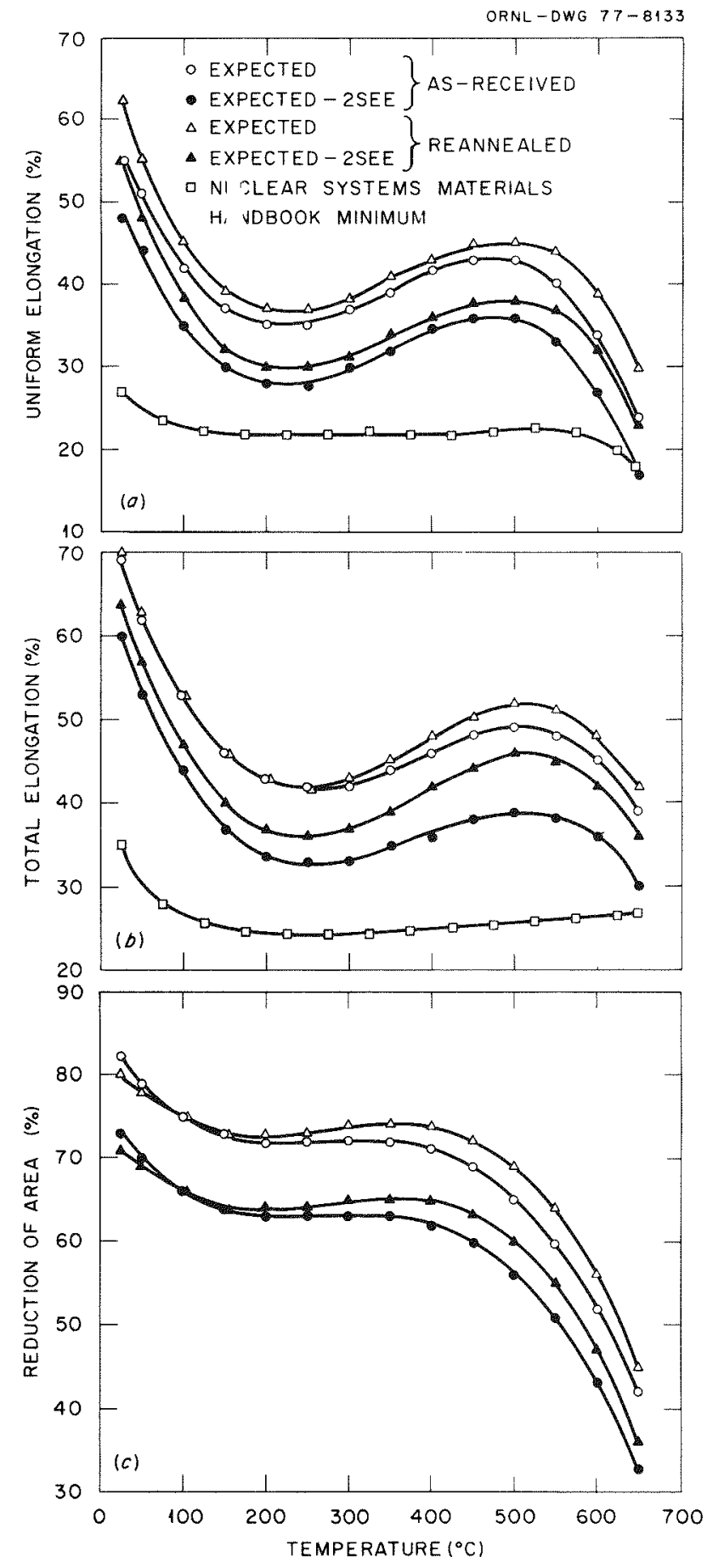

Fig. 52. Expected and Minimum Values for Various Ductility Quantities as Functions of Test Temperature for Ten Product Forms of the Reference Heat (8092297) of Type 316 Stainless Steel. Nuclear Systems Materials Handbook minimum values are also included in these plots. (a) Uniform elongation. (b) Total elongation. (c) Reduction of area. 
where

$$
\begin{aligned}
C= & \text { a measure of strength level and, as shown later, is related } \\
& \text { to yield strength, } \\
H= & \text { steady-state hardening rate }(d \sigma / d \varepsilon), \\
P= & \text { parameter describing the shape of the stress-strain curve } \\
& \text { before reaching the steady-state hardening, } \\
\sigma_{P L}= & \text { proportional limit of stress below which there is no plastic } \\
& \text { strain, } \\
e_{p}= & \text { true plastic strain. }
\end{aligned}
$$

The value $\sigma_{P L}$ was estimated to be $0.5 \sigma_{y}$, where $0.5 \sigma_{y}$ is the $0.2 \%$ offset yield strength. The constant $H$ is $2758 \mathrm{MPa}$, while $P$ is given by $500 C$. The value of $C$ is determined by the criterion that $\sigma=\sigma_{y}$ for $e_{p}=0.002$. Since a knowledge of stress and Young's modulus yields the magnitude of the elastic strain, Eq. (12) can be used to calculate the total strain corresponding to a given stress. The analysis of stressstrain behavior is fully described elsewhere. 20

Sikka and Booker ${ }^{21}$ and Hammond and Sikka ${ }^{7}$ have found excellent agreement between experimental stress-strain curves and those predicted by Eq. (12) for several heats of types 304 and 316 stainless steel. From this agreement, the model was considered to be reliable and accurate. Therefore, Eq. (12) was used to predict the maximum and minimum stressstrain curves (up to $4 \%$ ) for both the mill-annealed and reannealed product forms. These curves are compared with the range for experimental curves in Fig. 53. The maximum and minimum stress-strain curves were based on the average yield strength (Table 11) I2SEE (Table 10). Figure 53 shows the following:

1. The range of experimental curves for both mill-annealed and reannealed product forms is well described by tensile curves based on maximum and minimum yield strength values and the model given by Eq. (12).

2. The range of experimental curves for the reannealed product forms, Fig. 53(b), is significantly narrower than observed for the mill-annealed product forms. 

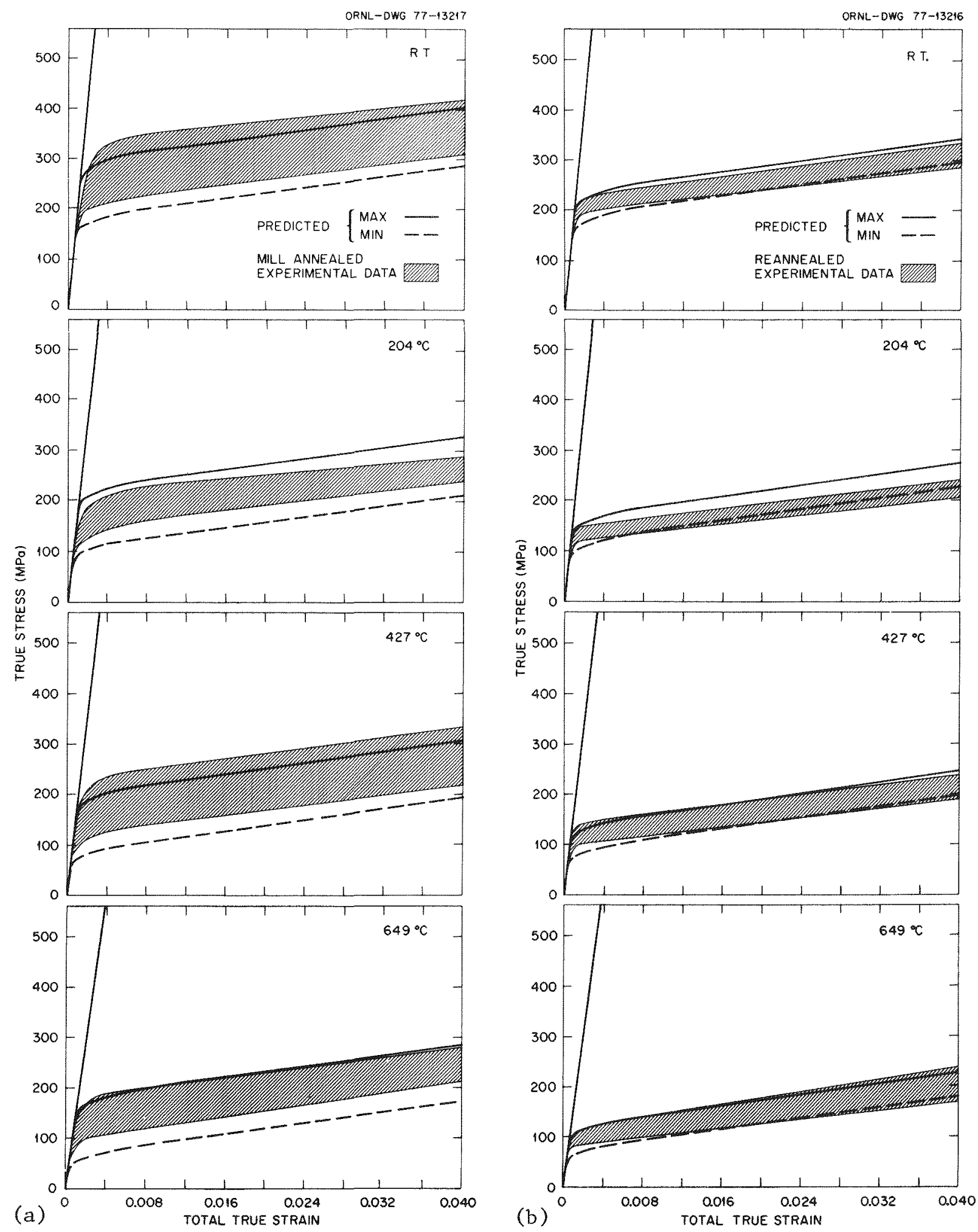

Fig. 53. Comparison of Experimental Stress-Strain Behavior with Predicted Maximum and Minimum Stress-Strain Curves for Ten Different Product Forms of the Reference Heat (8092297) of Type 316 Stainless Steel. (a) Mill-annealed material. (b) Reannealed material. 
Relation Between Room-Temperature Yield Strength and Hardness Values

In Table 4 we noted that the average room-temperature hardness of various product forms varied from 70.5 to $80.3 \mathrm{R}_{\mathrm{B}}$ for the mill-annealed product forms and from 64.9 to $71.5 \mathrm{R}_{\mathrm{B}}$ for the reannealed product forms. The $0.2 \%$ yield strength is known to increase with increasing hardness. To check if various product forms showed changes in yield strength corresponding to changes in hardness, data were plotted in Fig. 54. For 63.5-mm bar, hardness of the specimen tested at room-temperature in the as-received condition was $84.9 \mathrm{R}_{\mathrm{B}}$, compared with an average of 80.3 $R_{B}$ for the bar, and therefore the value for the individual specimen was used in Fig. 54. This figure also includes data for the reannealed product forms. The following observations can be made from Fig. 54.

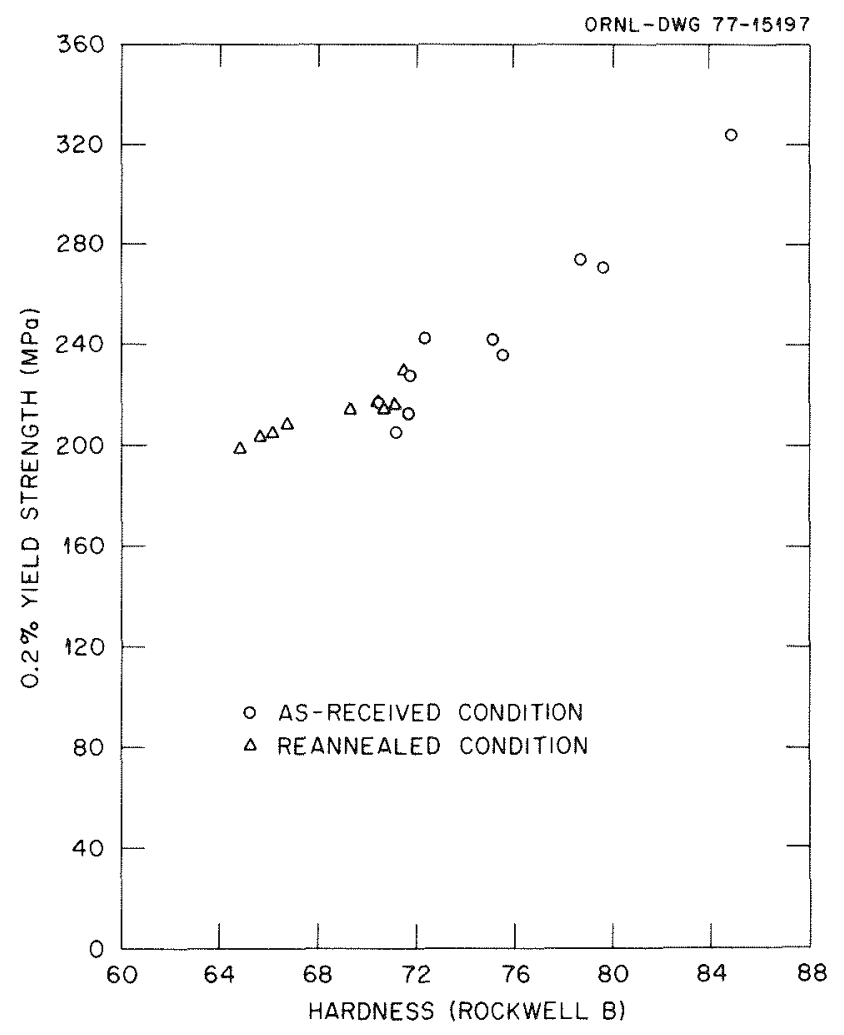

Fig. 54. Room-Temperature Yield Strength as a Function of Rockwell Hardness for As-Received and Reannealed Product Forms of the Reference Heat (8092297) of Type 316 Stainless Steel. 
1. The $0.2 \%$ yield strength increases with increase in room-temperature hardness.

2. The $0.2 \%$ yield strength and hardness being on the lower end for the reannealed product forms suggests that the additional hardness and the corresponding increased yield strength of the as-received material are associated with finishing operations performed after mi11annealing treatment. The reannealed data are more representative of the base line properties.

3. The hardness curve in Fig. 54 can be used to estimate the room-temperature $0.2 \%$ yield strength of a given product form in the range of the data.

\section{Comparison of $0.2 \%$ Yield Strength Data with Data on Previously Studied Heats}

The $0.2 \%$ yield strength data on pipe and bar products are compared with the range of data on previously studied heats in Fig. 55. The literature data ${ }^{22}$ were fitted to a third-degree polynomial in temperature. The dotted lines in these plots are for the expected $\pm 2 \mathrm{SEE}$. Superimposed in Fig. 55(a) are our data on as-received pipe of four different sizes. Data on all pipe made from the reference heat between the expected and lower bound curves. Figure 55 (b) shows that yield strength values of
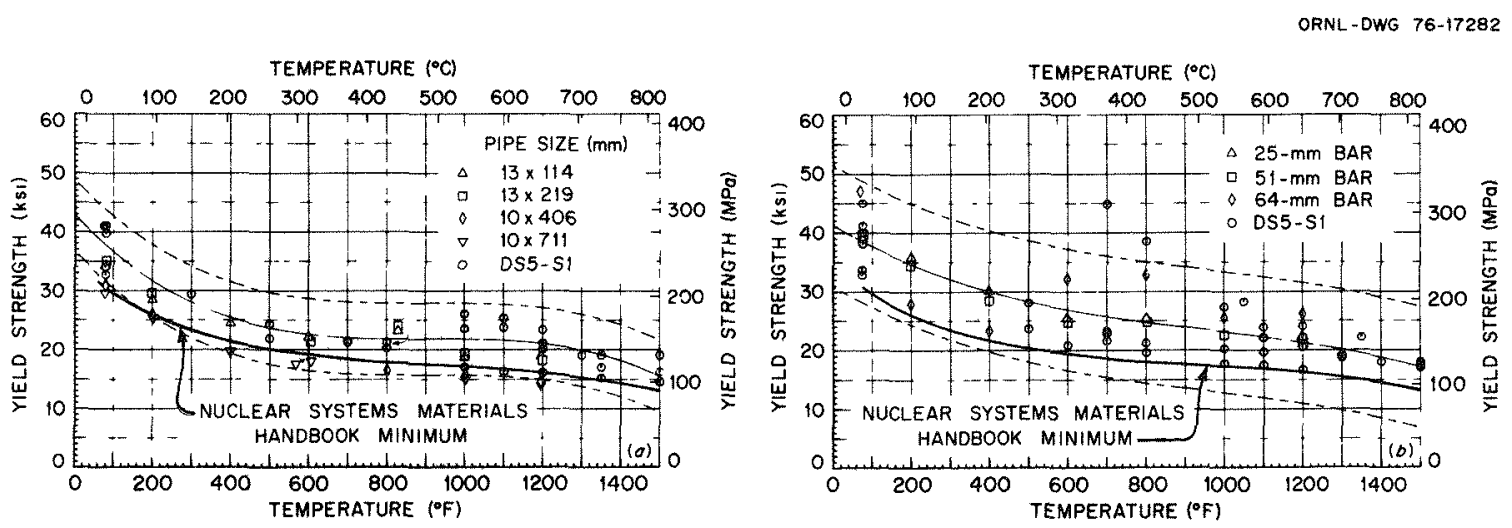

Fig. 55. Comparison of $0.2 \%$ Yield Strength Data on the Reference Heat of Type 316 Stainless Steel with the Range of Older Literature Data. (a) Pipe of four sizes. (b) Bar of three sizes. The solid line is a polynomial fit to the literature data; the dashed lines represent twice the standard error of estimate of the polynomial. 
bar products of the reference heat are close to or above the expectedvalue curves for the older heats. Considering the expected $\pm 2 \mathrm{SEE}$ method of defining the range of properties, the ORNL reference heat can be classified to fall within the range of the older heats. However, when compared with the Handbook minimum value curve, the 10 by $406-$ and 10 by 711-mm pipes of the reference heat will have to be considered different from or weaker than the older heats. Thus, it appears that the real answer to whether the ORNL reference heat, melted recentIy, is comparable with older heats depends on the method of defining the minimum values.

\section{Comparison of $0.2 \%$ Yield and Ultimate Tensile Strengths with} Vendor-Certified Mechanical Property Data

Certified room-temperature mechanical property data were supplied by the vendor on each product form of the reference heat. Figure 56 compares the certified data with ASTM minimum values and our values of $0.2 \%$ yield and ultimate tensile strength. The ORNL values were obtained at a strain rate of $0.004 / \mathrm{min}$ for material in both as-received and reannealed conditions.

Yield Strength - Figure 56(a) shows a significant difference between the certified data supplied by the vendor and the ORNL data. The plate and pipe product data supplied by the vendor were significantly higher than the data obtained at ORNL. However, the reverse was true for the bar product. The differences between the two data sources became even greater for reannealed plate and pipe products. Again the reverse was true for the bar products.

U1timate Tensile Strength - Figure 56(b) shows that only minimal differences existed for this property between the data supplied by the vendor and that obtained at ORNL. Such a result is expected because ultimate tensile strength values are relatively insensitive to residual stresses introduced by straightening and finishing (Fig. 37).

Previous work ${ }^{18,19}$ showed that $0.2 \%$ yield strength controls the time-independent design stresses for test temperatures below $600^{\circ} \mathrm{C}$. Therefore, the difference observed between the two data sets raises some questions about the significance of the certified mechanical property data supplied by the vendor. The differences observed between 

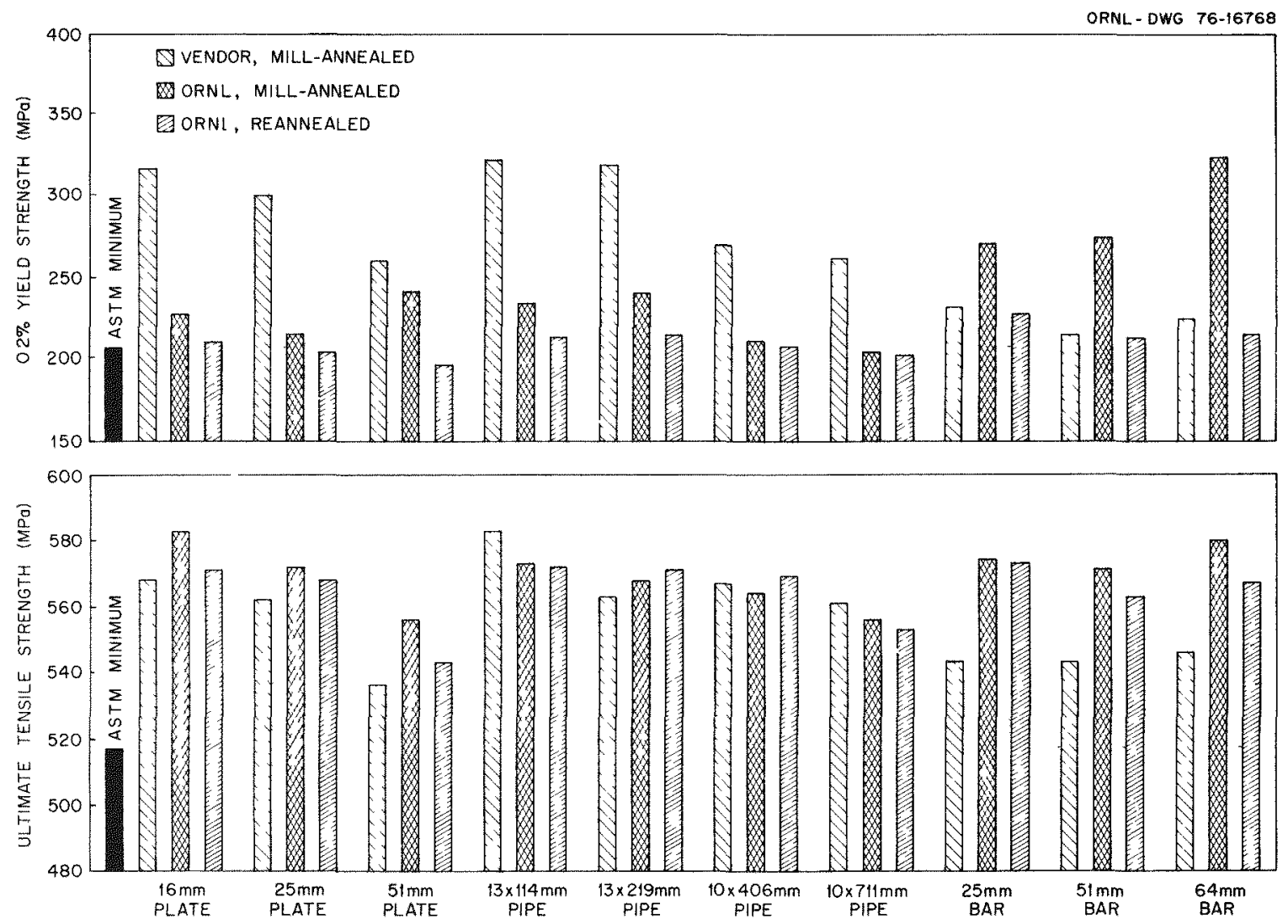

Fig. 56. Comparison of $0.2 \%$ Yield and Ultimate Tensile Strength Data with Certified Room-Temperature Properties Supplied by Vendors on Various Products of the Reference Heat (8092297) of Type 316 Stainless Steel.

the two data sets have further implications, if the vendor-certified room-temperature values of a given product were used in conjunction with yield strength ratios $^{23}$ to generate a yield strength versus temperature plot.

The vendor of the reference heat, Republic Steel, was contacted ${ }^{24}$ to establish possible reasons for differences observed between the ORNL data and certified data supplied by the vendor. The following possible explanations were offered for the differences for various products:

Bar Products - The vendor took specimens from bars after annealing. However, after taking specimens the bars were straightened and ground to size before shipping. Thus, the higher values observed by ORNL data are a result of residual cold work introduced in the bar by straightening 
and grinding. If the vendor's explanation is correct, ORNL reannealed data should agree with the certified value. Figure 56 shows that indeed ORNL reannealed data showed excellent agreement with the vendor data for all three bar products.

Plate Products - The vendor data on all plate products were higher than the ORNL data. Odar ${ }^{24}$ of Republic Steel suggested that for the plate products specimens were taken from the trimmed ends of plates, which contain more straightening work than plate away from the trimmed ends (a consequence of more buckling at ends during mill annealing). If such is the case the difference between the plate trims and the area away from the trimmed end is expected to decrease with increasing plate thickness. The ORNL tensile specimens were taken from the plate section away from the trimmed end. The decrease with increasing plate thickness is confirmed by results presented in Fig. 56.

Pipe Products - The vendor data on all pipe products were higher than the values obtained at ORNL and the vendor has no satisfactory explanation for such an observation. However, Rollnet ${ }^{25}$ and Republic Steel have been working with us to check the differences in machining specimens and testing procedures. Data from this program are summarized in Table 15. Al1 tests were on two pieces of 10 by $711-\mathrm{mm}$ pipes. The ORNL specimens were made by Tasco, whereas Atlas made specimens for Rol1met. Al1 but one specimen were tested with an Instron machine. One specimen was tested with a Baldwin machine. Data in Table 15 show the following:

1. ORNL data show that specimens machined by Tasco or Atlas give the same results.

2. Instron data are in close agreement with Baldwin machine data.

3. Axial and circumferential test data show that Rollmet process produces an isotropic pipe product.

4. Both ORNL and Republic Steel data are in excellent agreement, whereas Rollmet obtained slightly higher values.

5. Yield strengths obtained at ORNL, Republic Steel, and Rollmet are significantly lower than the vendor-certified results reported in Table 16. 
Table 15. Summary of Room-Temperature Tensile Data (at a Strain Rate of $0.004 / \mathrm{min}$ ) Obtained at Various Laboratories on 10 by $711-\mathrm{mm}$ Pipe of the Reference Heat of Type 316 Stainless Steel

\begin{tabular}{|c|c|c|c|c|c|c|c|c|}
\hline \multirow{2}{*}{ Specimen $^{a}$} & \multirow{2}{*}{$\begin{array}{c}\text { Specimen } \\
\text { Manufacturer }\end{array}$} & \multirow{2}{*}{$\begin{array}{c}\text { Testing } \\
\text { Laboratory }\end{array}$} & \multicolumn{3}{|c|}{ Strength, MPa (ksi) } & \multicolumn{2}{|c|}{ Elongation $(\%)$} & \multirow{2}{*}{$\begin{array}{c}\text { Reduction of } \\
\text { Area } \\
(\%)\end{array}$} \\
\hline & & & & ield & Ultimate & Uniform & $\begin{array}{c}\text { Total } \\
\text { in } 25.4 \mathrm{~mm}\end{array}$ & \\
\hline $3 \mathrm{G} 1 \mathrm{~A}$ & $\begin{array}{l}\text { ORNL } \\
\text { (TASCO) }\end{array}$ & $\mathrm{ORNL}^{\mathrm{b}}$ & 216 & $(31.3)$ & & & & \\
\hline $3 \mathrm{G} 2 \mathrm{~A}$ & $\begin{array}{l}\text { ORNL } \\
\text { (TASCO) }\end{array}$ & ORNZ & 208 & $(30.1)$ & $561(81.3)$ & 58.0 & 67.2 & 80.3 \\
\hline $3 \mathrm{G} 4 \mathrm{C}$ & $\begin{array}{l}\text { ORNL } \\
\text { (TASCO) }\end{array}$ & ORNL & 210 & $(30.5)$ & $556(80.7)$ & 60.6 & 66.2 & 69.6 \\
\hline $5 \mathrm{G} 2 \mathrm{~A}$ & $\begin{array}{l}\text { ORNL } \\
\text { (TASCO) }\end{array}$ & ORNL & 211 & $(30.6)$ & $561(81.3)$ & 60.0 & 71.6 & 79.9 \\
\hline $5 \mathrm{G} 4 \mathrm{C}$ & $\begin{array}{l}\text { ORNL } \\
\text { (TASCO) }\end{array}$ & ORNL & 208 & $(30.1)$ & $553(80.2)$ & 60.3 & 67.1 & 68.3 \\
\hline $5 \mathrm{G} 5 \mathrm{~A}$ & $\begin{array}{l}\text { Ro11met } \\
\text { (ATLAS) }\end{array}$ & ORNL & 212 & $(30.8)$ & $580(84.1)$ & 71.1 & 80.6 & 79.1 \\
\hline $5 \mathrm{G} 8 \mathrm{C}$ & $\begin{array}{l}\text { Rollmet } \\
\text { (ATLAS) }\end{array}$ & ORNL & 207 & $(30.1)$ & $549(79.6)$ & 71.3 & 77.7 & 70.5 \\
\hline $5 \mathrm{G} 6 \mathrm{~A}$ & $\begin{array}{l}\text { Rollmet } \\
\text { (ATLAS) }\end{array}$ & $\begin{array}{l}\text { Republic } \\
\text { Steel }\end{array}$ & 212 & $(30.8)$ & $548(79.5)$ & c & c & c \\
\hline $5 \mathrm{G} 9 \mathrm{C}$ & $\begin{array}{l}\text { Rollmet } \\
\text { (ATLAS) }\end{array}$ & $\begin{array}{l}\text { Republic } \\
\text { Steel }\end{array}$ & 214 & $(31.1)$ & $532(77.2)$ & c & $c$ & c \\
\hline $5 \mathrm{G} 7 \mathrm{~A}$ & $\begin{array}{l}\text { Rollmet } \\
\text { (ATLAS) }\end{array}$ & At 1 as & 224 & $(32.5)$ & $557(80.8)$ & c & 63.0 & 79.0 \\
\hline $5 \mathrm{G} 10 \mathrm{C}$ & $\begin{array}{l}\text { Rollmet } \\
\text { (ATLAS) }\end{array}$ & Atlas & 223 & $(32.3)$ & $549(79.6)$ & c & 61.0 & 69.0 \\
\hline
\end{tabular}

${ }^{\mathrm{a}}$ Specimen numbers ending with $\mathrm{A}$ represent axial specimen, whereas numbers ending with $\mathrm{C}$ represent circumferential specimens.

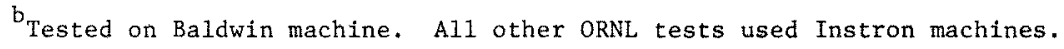

${ }^{c}$ Data not provided.

Table 16. Summary of Certified Mechanical Properties ${ }^{a}$ of 10 by $711-\mathrm{mm}$ Pipe made by Rollmet of Type 316 Stainless Steel Reference Heat (8092297)

\begin{tabular}{|c|c|c|c|c|c|}
\hline \multirow{2}{*}{ Identity } & \multicolumn{3}{|c|}{ Strength, $\mathrm{MPa}$ (ksi) } & \multirow{2}{*}{$\underset{(\%)}{\text { E1ongation }}$} & \multirow{2}{*}{$\begin{array}{c}\text { Reduction of } \\
\text { Area } \\
(\%)\end{array}$} \\
\hline & & Yield & Ultimate & & \\
\hline CF-003 & 262 & $(38.05)$ & $563(81.70)$ & 61.0 & 76.1 \\
\hline$C F-003 G$ & 258 & $(37.45)$ & $560(81.25)$ & 56.0 & 78.1 \\
\hline $\mathrm{CF}-004$ & 279 & $(40.40)$ & $560(81.25)$ & 56.3 & 63.9 \\
\hline CF-004G & 265 & $(38.45)$ & $557(80.75)$ & 56.3 & 65.9 \\
\hline CF-005 & 251 & $(36.40)$ & $561(81.40)$ & 60.0 & 78.3 \\
\hline$C F-005 G$ & 258 & $(37.40)$ & $566(82.10)$ & 56.0 & 74.4 \\
\hline
\end{tabular}

${ }_{\mathrm{A} 11}$ tests were performed in the circumferential direction. 
6. The reasons for differences between the certified and laboratory data are still not clear. ORNL, Republic, and Rollmet are working together to find an explanation.

In summary it may be stated that while laboratory tests at three different locations produced the same results, the significantly higher values of the certified tests (used in meeting the ASTM material specifications) raise some questions about their value.

\section{SUMMARY AND CONCLUSIONS}

The product form characterization of reference heat (8092297) of type 316 stainless steel was completed. Ten product forms were studied: three plates, four pipes, and three bars. The characterization process involved lescription of melting, fabrication processes, composition variations, optical microstructure and grain size, room temperature Rockwell and microhardness data, and tensile properties in both millannealed and reannealed conditions. Residual cold work in various product forms was estimated from the tensile properties. Tensile data were modeled and compared with a "minimum" value curve. Stress-strain curves (up to $4 \%$ ) were predicted and compared with the experimental data. Roomtemperature tensile properties on various product forms were compared with the vendor certified data. Following are some important observations and conclusions:

1. All ten product forms showed essentially the same composition.

2. Some grain size differences were observed between the outer and inner surfaces of all pipes and the outer surface and the center of the 51- and 64-mm bars in the as-received condition. However, reannealing for $0.5 \mathrm{hr}$ at $1065^{\circ} \mathrm{C}$ did not significantly change grain size.

3. The 51- and $64-\mathrm{mm}$ bars showed substantial hardness gradients from the outer edge to the center of the bar. Such gradients were not observed in the 25-mm bar, but hardness data showed large variations. The plate products also showed hardness gradients from the edges to the center.

4. All bar products showed higher hardness values in the as-received condition than did the plate and pipe products. However, all product forms approached approximately the same hardness on annealing for $0.5 \mathrm{hr}$ at $1065^{\circ} \mathrm{C}$. 
5. The $0.2 \%$ yield strength data showed maximum differences between the various products in the as-received condition. Plate and pipe were weaker than bar. The room-temperature yield strength value for 10 by $711-\mathrm{mm}(0.4 \times 28 \mathrm{in.})$ pipe was slightly below the ASTM minimum specified value of $207 \mathrm{MPa}$ (30 ksi). Results also showed that meeting the roomtemperature specified value did not assure the elevated-temperature values to fall above the Nuclear Systems Materials Handbook minimum curve.

6. Reannealing lowered the yield strength of a11 product forms. Some of the product forms met the room-temperature ASTM minimum specified value of $207 \mathrm{MPa}(30.0 \mathrm{ksi})$. However, all product forms except two bars showed yield strength values below the Handbook minimum at elevated temperature.

7. U1timate tensile strength, uniform and total elongation, and reduction of area were not significantly different between the various products in the as-received condition.

8. Ultimate tensile strength was not significantly altered by laboratory reannealing. However, uniform and total elongation and reduction of area increased on reannealing for all product forms.

9. The reannealed $0.2 \%$ yield strength and uniform elongation were plotted as functions of as-received values. The intercepts of lines of unit slope through the data gave measures of residual cold work in terms of stress and strain. The stress and strain ranges for various product forms were 8 to $52 \mathrm{MPa}$ and 1.5 to $6.5 \%$, respectively.

10. The residual cold work was different for different product forms. Large pipe made by roll extrusion showed the least residual cold work, while bar product forms showed the most.

11. Reannealing for $0.5 \mathrm{hr}$ at $1065^{\circ} \mathrm{C}$ did not produce any change in grain size for any of the ten product forms.

12. Total variations for all ten product forms, measured as standard error of estimate (SEE), were significantly greater for all tensile properties in the as-received condition than in the reannealed condition. Among other properties, yield strength showed the greatest variation. 
13. Twenty-four room-temperature tests on $16-\mathrm{mm}$ plate in the reannealed condition showed an SEE of $1 \mathrm{MPa}$ for yield strength. The SEE of $1 \mathrm{MPa}$ indicated that variations within the same reannealed product form and variations due to testing procedure were negligible.

14. The SEE for yield strength of ten product forms in the reannealed condition was $11.6 \mathrm{MPa}$. The total variation about the expected value was measured by $\pm 2 \mathrm{SEE}$, and therefore an SEE of $11.6 \mathrm{MPa}$ produces a variation of approximately $\pm 23 \mathrm{MPa}$ in reannealed yield strength of various product forms.

15. Cold-worked-and-annealed specimens were studied to show that the observed variations in yield strength of various product forms were associated with varying amounts of cold work in these products through its influence on recovery and recrystallization behavior. This was supported by optical microstructural observations.

16. Variations in ultimate tensile strength and ductility were also explained from the study on cold-worked-and-annealed specimens.

17. The data on cold-worked-and-annealed specimens showed that for a certain cold work range ( 6 to $10 \%$ ), reannealing at $1065^{\circ} \mathrm{C}$ can 1 ower the yield strength of type 316 stainless steel below the room-temperature minimum specified value of $207 \mathrm{MPa}$.

18. The expected-value curve of reannealed yield strength was approximately $29 \mathrm{MPa}$ below the as-received curve.

19. The NSMH minimum value curve was not only above the reannealed average curve, but also significantly higher than the as-received minimum curve. Similar observations were previous $1 y^{18,19}$ made for type 304 stainless steel.

20. Yield strength data on bar and pipe product forms showed that the ORNL reference heat is comparable to previously studied heats.

21. Certified $0.2 \%$ yield strength data supplied by the vendor differed significantly from the ORNL data.

22. A single rational polynomial tensile model could describe the stress-strain range in experimental data for all product forms. 


\section{ACKNOWLEDGMENTS}

The author gratefully acknowledges L. T. Ratcliff for performing tensile tests, R. H. Baldwin for analyzing tensile data, M. K. Booker and B.L.P. Booker for regression analysis, and C. W. Houck for metallography. Thanks are also due to M. K. Booker, J. P. Strizak, C. R. Brinkman, G. M. Slaughter, and P. Patriarca for reviewing, Sigfred Peterson for editing, and Denise Jackson for typing the manuscript.

\section{REFERENCES}

1. H. E. McCoy, Jr., and R. D. Waddel1, Jr., "Mechanical Properties of Several Products from a Single Heat of Type 304 Stainless Steel," J. Eng. Mater. Technol. 97: 343-49 (1975).

2. R. W. Swindeman, Room-Temperature Characterization Data for Type 304 Stainless Steel (Heat 9T2796) Plate, ORNL/TM-4396 (February 1974).

3. R. W. Swindeman, W. J. McAfee, and V. K. Sikka, "Product Form Variability in the Mechanical Behavior of Type 304 Stainless Steel at $593^{\circ} \mathrm{C}, "$ pp. 41-64 in Reproducibility and Accuracy of Mechanical Tests, ASTM Spec. Tech. Publ. 626, American Society for Testing and Materials, Philadelphia, May 1977.

4. V. K. Sikka, "Tensile Properties of Several Products from a Single Heat (8092297) of Type 316 Stainless Steel," report in preparation, 1977.

5. H. E. McCoy, Interim Report of Tensile and Creep Data for Type 304 Stainless Steel Plate (Reference Heat 9T2796, 2 in. Thick), ORNL/TM-4627 (October 1974).

6. H. E. McCoy, Tensize and Creep Properties of Several Heats of Type 304 Stainless Steel, ORNL/TM-4709 (November 1974).

7. J. P. Hammond and V. K. Sikka, Heat-to-Heat Variation of Total Strain (to 5\%) at Discrete Stress Levels in Types 316 and 304 Stainless Steel from 24 to $316^{\circ} \mathrm{C}$, ORNL/NUREG/TM-57 (December 1976). 
8. V. K. Sikka, H. E. McCoy, M. K. Booker, and C. R. Brinkman, "Heat-to-Heat Variation in Creep Properties of Types 304 and 316 Stainless Stee1,"J. Pressure Vessel Technol. 97: 243-51 (1975).

9. V. K. Sikka, R. W. Swindeman, T. L. Hebble, C. R. Brinkman, and M. K. Booker, "Residual Cold Work and Its Influence on Tensile and Creep Properties of Types 304 and 316 Stainless Steels, "Nucl. Technol. 31: 96-114 (1976).

10. V. K. Sikka, T. L. Hebble, M. K. Booker, and C. R. Brinkman, Influence of Laboratory Annealing on Tensize Properties and TimeIndependent Design Stress Intensity Limits for Type 304 Stainless Steel, ORNL-5175 (December 1976).

11. V. K. Sikka, C. R. Brinkman, and H. E. McCoy, Jr., "Effect of Thermal Aging on Tensile and Creep Properties of Types 304 and 316 Stainless Stee1s," pp. 316-50 in Stmuctural Materials for service at Elevated Temperatures in Nuclear Power Generation, MPC-1, ed. by A. 0. Schaefer, American Society of Mechanical Engineers, New York, 1975.

12. V. K. Sikka and C. R. Brinkman, Uniaxial Tensile Properties of Austenitic Stainless Steels Following Prior Creep Deformation - An Interim Report, ORNL/TM-5193 (April 1976).

13. R. J. Beaver and W. R. Martin, Procurement of Type 316 Staintess Steel Reference Heat for LMFBR Research and Development Program, ORNL/TM-5196 (January 1976).

14. Hanford Engineering Development Laboratory, Nuclear Systems Materials Handbook, TID-26666 (continually updated).

15. J. E. Hillard, "Estimating Grain Size by the Intercept Method," Met. Progr. 85: 99-102 (1964).

16. E 151-64, "Recommended Practice for Tension Tests on Metallic Materials at Elevated Temperatures with Rapid Heating and Conventional or Rapid Strain Rates," Book of ASTM Standards, Part 31, American Society for Testing and Materials, Philadelphia, 1971, pp. 521-28.

17. V. K. Sikka, R. W. Swindeman, and C. R. Brinkman, "Elevated Temperature Tensile Ductility Minima in Types 304 and 316 Stainless Stee1," in Fracture 1977, vo1. 2, ICF4, Waterloo, Canada, June 19-24, 1977. 
18. V. K. Sikka and M. K. Booker, "Influence of Laboratory Annealing on Tensile Properties and Design Stress Intensity Limits for Type 304 Stainless Steel," accepted for publication at ASME winter meeting, November 1977.

19. V. K. Sikka et a1., Tensile Properties of Type 304 Stainzess Steel, ORNL-5325 (in prepartion).

20. V. K. Sikka, M. K. Booker, and J. P. Hammond, Rational Polynomial Tensile Stress-Strain Equation for Low-Strain Behavior of Types 304 and 316 stainless Steel, report in preparation.

21. V. K. Sikka and M. K. Booker, "Mechanical Property Characterization of Type 316 Stainless Steel Reference Heat," Mechanical Properties Test Data for Stmuctural Materials Quart. Prog. Rep. April 30, 1976 , ORNL-5150, pp. 55-63.

22. W. F. Simmons and J. A. Van Echo, Report on the EZevated-Temperature Properties of Stainless SteeZs, ASTM Data Ser. DS 5 S1, American Society for Testing and Materials, Philadelphia, 1965.

23. G. V. Smith, An Evaluation of the Yiezd, Tensize, Creep, and Rupture Strength of Wrought 304, 316, 321, and 347 Stainless Steels at Elevated Temperatures, ASTM Data Ser. DS 5 S2, American Society for Testing and Materials, Philadelphia, February 1969.

24. J. Odar, Republic Steel Co., Canton, Ohio, private communication, August 1977.

25. D. Corn, Rollmet, Inc., Irvine, Calf., private communication, August 1977. 
APPENDIX A

HEAT TREATMENT BACKUP WORK 
0

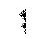

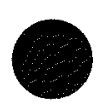




\section{HEAT TREATMENT BACKUP WORK}

The following backup work was performed to determine a suitable reannealing heat treatment. Four product forms - 16-mm (5/8-in.) plate, 25-mm (1-in.) plate, 69-mm (2.5-in.) pipe, and 219-mm (8 5/8-in.) pipe of the reference heat were used in the program. These products were given the following reannealing treatments:

1. cold furnace $+0.5 \mathrm{hr}$ at $1065^{\circ} \mathrm{C}\left(1950^{\circ} \mathrm{F}\right)$, followed by air cooling;

2. hot furnace at $1065^{\circ} \mathrm{C}\left(1950^{\circ} \mathrm{F}\right)+0.5 \mathrm{hr}$ at $1065^{\circ} \mathrm{C}\left(1950^{\circ} \mathrm{F}\right)$, followed by air cooling;

3. hot furnace at $800^{\circ} \mathrm{C}\left(1472^{\circ} \mathrm{F}\right)+1 \mathrm{hr}$ at $816^{\circ} \mathrm{C}\left(1500^{\circ} \mathrm{F}\right)+0.5 \mathrm{hr}$ at $1065^{\circ} \mathrm{C}\left(1950^{\circ} \mathrm{F}\right)$, followed by air cooling.

A11 reanneals were performed in an argon atmosphere. The air cooling rates were approximately $2000^{\circ} \mathrm{C} / \mathrm{hr}\left(3600^{\circ} \mathrm{F} / \mathrm{hr}\right)$ from 1065 to $420^{\circ} \mathrm{C}$ $\left(1950\right.$ to $\left.788^{\circ} \mathrm{F}\right)$.

As-received (mill-annealed) and reannealed (laboratory-annealed) aged blocks and specimens were subjected to the following tests:

1. room-temperature hardness, Rockwell B;

2. room-temperature tensile tests;

3. optical grain size determination on specimens etched electrolytically in $10 \%$ nitric acid solution.

Room-temperature hardness for various reanneal treatments are summarized in Table Al and grain size measurements are summarized in Table A2. Changes in microstructure resulting from various heat treatments

Table Al. Effect of Annealing on Room-Temperature Hardness of the Reference Heat of Type 316 Stainless Stee1

\begin{tabular}{|c|c|c|c|c|}
\hline \multirow[b]{2}{*}{ Product } & \multicolumn{4}{|c|}{ Hardness, $R_{B}$} \\
\hline & $\begin{array}{c}\text { As } \\
\text { Received }\end{array}$ & $\begin{array}{c}\text { Cold Furnace } \\
+0.5 \mathrm{hr} \text { at } \\
1065^{\circ} \mathrm{C}\end{array}$ & $\begin{array}{l}\text { Hot Furnace } \\
+0.5 \mathrm{hr} \text { at } \\
1065^{\circ} \mathrm{C}\end{array}$ & $\begin{array}{c}\text { Hot Furnace } \\
+1 \mathrm{hr} \text { at } 816^{\circ} \mathrm{C} \\
+0.5 \mathrm{hr} \text { at } 1065^{\circ} \mathrm{C}\end{array}$ \\
\hline 16-mm (5/8-in.) plate & 72.1 & 70.0 & 69.9 & 71.2 \\
\hline 25-mm (1-in.) plate & 76.6 & 70.7 & 71.7 & \\
\hline $\begin{array}{l}\text { 64-mm }(2.5 \text {-in.) pipe } \\
\text { wall } \\
\text { outer surface } \\
\text { inner surface }\end{array}$ & $\begin{array}{l}75.5 \\
81.8 \\
80.0\end{array}$ & & $\begin{array}{l}71.2 \\
59.2 \\
73.4\end{array}$ & $\begin{array}{l}71.8 \\
64.9 \\
73.7\end{array}$ \\
\hline 219-mm (8 5/8-in.) pipe & 75.6 & 72.4 & 72.1 & \\
\hline
\end{tabular}


Table A2. Summary of Grain Sizes for Reference Heat of Type 316 Stainless Steel

\begin{tabular}{|c|c|c|c|c|c|c|c|c|}
\hline \multirow{3}{*}{ Product } & \multicolumn{8}{|c|}{ Grain Size, ASTM $(\mu \mathrm{m})$} \\
\hline & \multicolumn{2}{|c|}{ As Received } & \multicolumn{2}{|c|}{$\begin{array}{l}\text { Cold Furnace Plus } \\
0.5 \text { hr at } 1065^{\circ} \mathrm{C}\end{array}$} & \multicolumn{2}{|c|}{$\begin{array}{l}\text { Hot Furnace Plus } \\
0.5 \text { hr at } 1065^{\circ} \mathrm{C}\end{array}$} & \multicolumn{2}{|c|}{$\begin{array}{c}\text { Hot Furnace Plus } 1 \mathrm{hr} \\
\text { at } 816^{\circ} \mathrm{C} \text { and } 0.5 \mathrm{hr} \\
\text { at } 1065^{\circ} \mathrm{C}\end{array}$} \\
\hline & $\begin{array}{l}\text { Without } \\
\text { Twins }\end{array}$ & $\begin{array}{l}\text { With } \\
\text { Twins }\end{array}$ & $\begin{array}{l}\text { Without } \\
\text { Twins }\end{array}$ & $\begin{array}{l}\text { With } \\
\text { Twins }\end{array}$ & $\begin{array}{l}\text { Without } \\
\text { Twins }\end{array}$ & $\begin{array}{l}\text { With } \\
\text { Twins }\end{array}$ & $\begin{array}{l}\text { Without } \\
\text { Twins }\end{array}$ & $\begin{array}{l}\text { With } \\
\text { Twins }\end{array}$ \\
\hline 16-mm Plate Longitudinal & $5.3(50)$ & $6.2(37)$ & $3.7(86)$ & $5.6(44)$ & $3.6(90)$ & $5.5(46)$ & $4(80)$ & $5.3(50)$ \\
\hline 16-mm Plate Transverse & $5.4(48)$ & $6.4(34)$ & $4.6(64)$ & $6.1 \quad(37)$ & $50(56)$ & $5.8(41)$ & $5.5(46)$ & $6.2(36)$ \\
\hline \multicolumn{9}{|l|}{ 64-mm Pipe Transverse } \\
\hline Wal1 & $6.7(31)$ & $7.5(27)$ & & & $5.4(48)$ & $6.2(36)$ & & \\
\hline Outside & $7.2(24)$ & $8.0(19)$ & & & $4.2(74)$ & $5.5(46)$ & $3.7(85)$ & $4.7(60.5)$ \\
\hline Inside & $6.5(33)$ & $7.4(24)$ & & & $6.0(38)$ & $7.0(27.5)$ & $5.6(44)$ & $6.7(31)$ \\
\hline \multicolumn{9}{|l|}{ 64-mm Pipe Longitudinal } \\
\hline Outside & & & & & & & $2.7(122)$ & $5.6(45)$ \\
\hline Inside & & & & & & & $5.8(42)$ & $6.9(28)$ \\
\hline \multicolumn{9}{|l|}{ 219-mm Pipe } \\
\hline Outside & $5.8(42)$ & $6.7(31)$ & $3.2(100)$ & $4.8(60)$ & $3(110)$ & $4.3(70)$ & & \\
\hline Inside & & & & & $5.4(48)$ & $6.7(31)$ & & \\
\hline
\end{tabular}


of the 16-mm (5/8-in.) plate and 64-mm (2.5-in.) pipe are shown in Figs. Al through A5. Note that the reannealing treatments produced a fairly uniform microstructure for the 16-mm plate, whereas the reannealed microstructure of the $64-\mathrm{mm}$ pipe varied across the pipe wall. The inside surface of the pipe was highly distorted in the as-received condition (Fig. A3), and it developed surface cracks on reannealing (Fig. A5). The outside surface of the pipe showed excessive grain growth on reannealing (Figs. A4 and A5). Consistent with microstructure, the hardness of the outside surface dropped from an average of 81.8 to $64.9 \mathrm{R}_{\mathrm{B}}$ (Table $\mathrm{A} 1$ ). All other products of the reference heat showed only small changes in hardness, and, furthermore, these changes were essentially the same for all heat treatments used. The initial temperature (cold or hot) of the reannealing furnace had apparently little or no influence on the final hardness and microstructure.

The ASTM Material Specifications ${ }^{1-3}$ A 240 (plate), A 312 (pipe), and A 479 (bar) suggest that the heat treatment given these products should be such as to result in specified mechanical properties. One of these requirements is that the room temperature $0.2 \%$ yield strength shall not be less than $30 \mathrm{ksi}$ (207 MPa). The Metals Handbook ${ }^{4}$ lists the following considerations in selecting a proper annealing temperature for austenitic stainless steels:

1. Carbides precipitate between 427 and $900^{\circ} \mathrm{C}\left(800-1650^{\circ} \mathrm{F}\right)$, and thus the annealing temperature should be above this range.

2. Because all carbides should be in solution before cooling begins, and because the chromium carbide dissolves slowly, the highest practical temperature consistent with limited grain growth should be selected. This temperature is in the vicinity of $1093^{\circ} \mathrm{C}\left(2000^{\circ} \mathrm{F}\right)$.

3. Cooling from the annealing temperature must be rapid, but not rapid enough to distort the specimen.

For type 316 stainless steel, the recommended ${ }^{4}$ annealing temperature range is 1038 to $1121^{\circ} \mathrm{C}\left(1900\right.$ to $\left.2050^{\circ} \mathrm{F}\right)$. The time at the selected annealing temperature should be 3 to $5 \mathrm{~min}$ per $2.5 \mathrm{~mm}(0.10 \mathrm{in}$.) of thickness. 

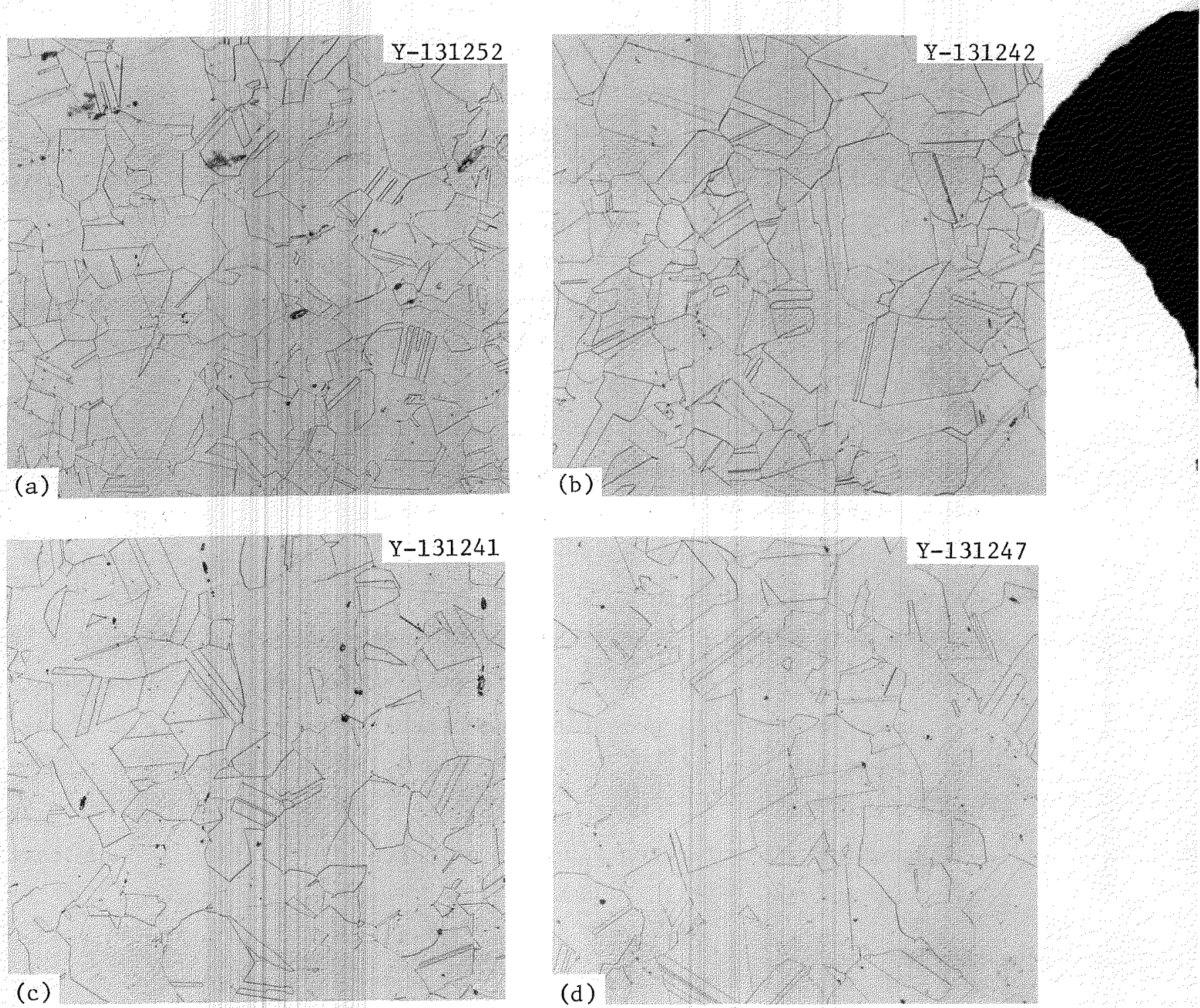

Fig. A1. Microstructure of As-Received and Reannealed 16-mm (5/8-in.) Plate of the Reference Heat of Type 316 Stainless Stee1. Longitudinal sections. 100x. (a) A 240. (b) A $240+$ Cold Furnace +0.5 hr at $1065^{\circ} \mathrm{C}$. (c) A $240+$ Hot Furnace $\left(1065^{\circ} \mathrm{C}\right)+0.5 \mathrm{hr}$ at $1065^{\circ} \mathrm{C}$. (d) A $240+\mathrm{Hot}$ Furnace $\left(800^{\circ} \mathrm{C}\right)+1 \mathrm{hr}$ at $816^{\circ} \mathrm{C}+0.5 \mathrm{hr}$ at $1065^{\circ} \mathrm{C}$. 

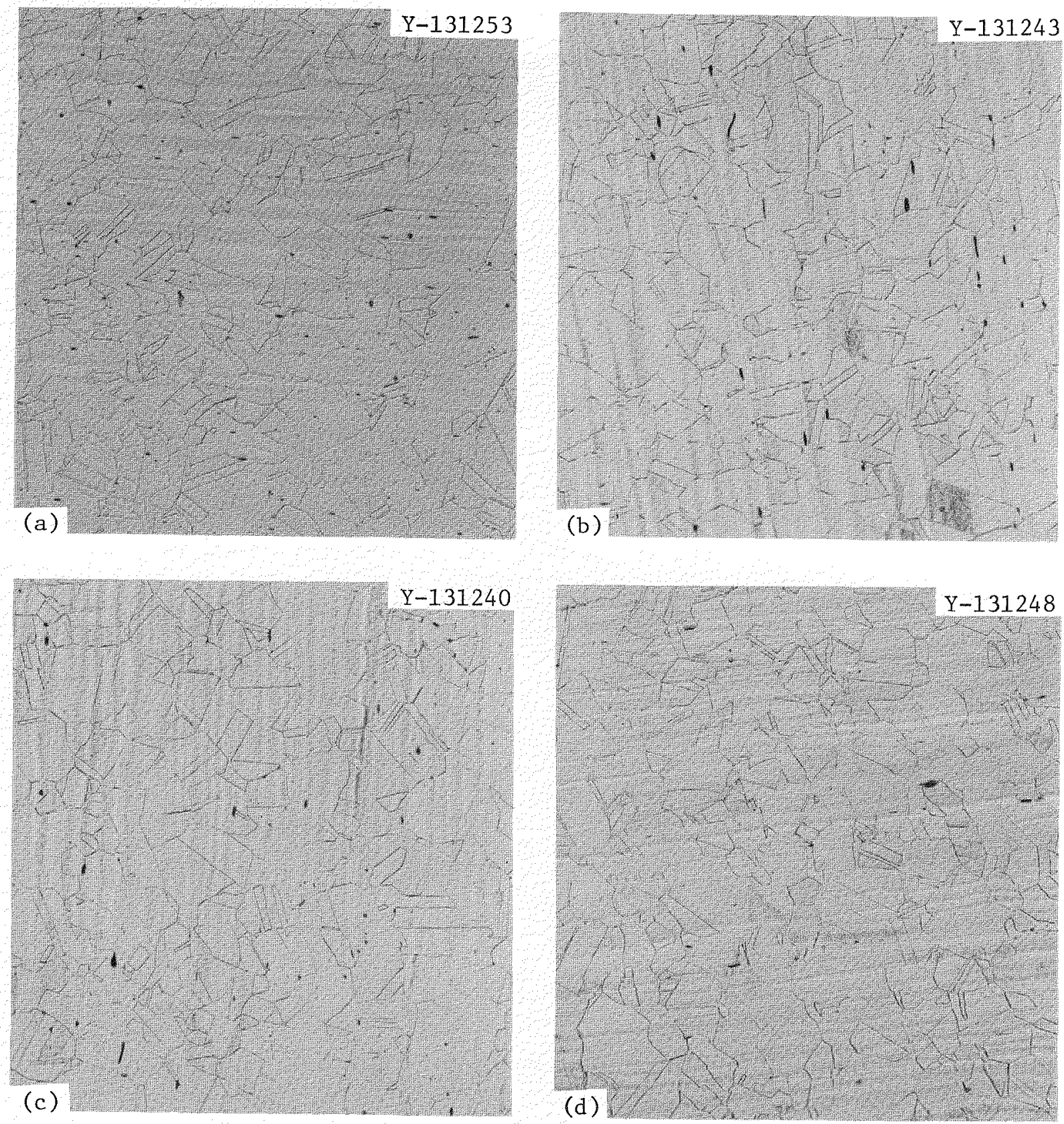

Fig. A2. Microstructure of As-Received and Reannealed 16-mm (5/8-in.) Plate of the Reference Heat of Type 316 Stainless Stee1. Transverse sections. 100x. (a) A 240 . (b) A $240+$ Cold Furnace +0.5 hr at $1065^{\circ} \mathrm{C}$. (c) A $240+$ Hot Furnace $\left(1065^{\circ} \mathrm{C}\right)+0.5$ hr at $1065^{\circ} \mathrm{C}$. (d) A $240+$ Hot Furnace $\left(800^{\circ} \mathrm{C}\right)+1$ hr at $816^{\circ} \mathrm{C}+0.5 \mathrm{hr}$ at $1065^{\circ} \mathrm{C}$. 

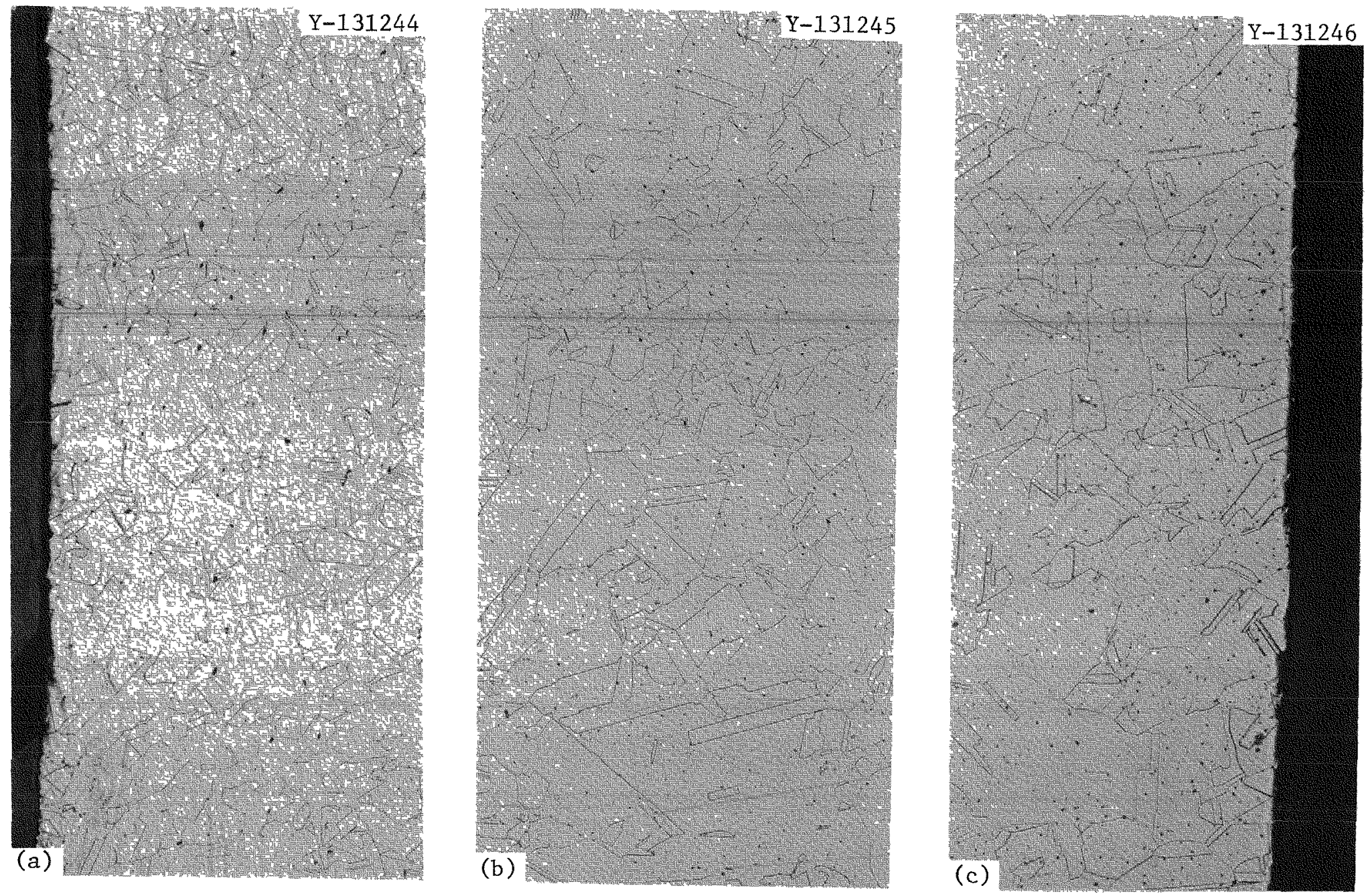

Fig. A3. Microstructure of Reannealed (Hot Furnace, $0.5 \mathrm{hr}$ at $1065^{\circ} \mathrm{C}$ ) $64-m m(2.5-$ in.) Pipe of the Reference Heat of Type 316 Stainless Stee1. 100x. (a) Inside surface. (b) Midthickness, (c) Outside surface. 

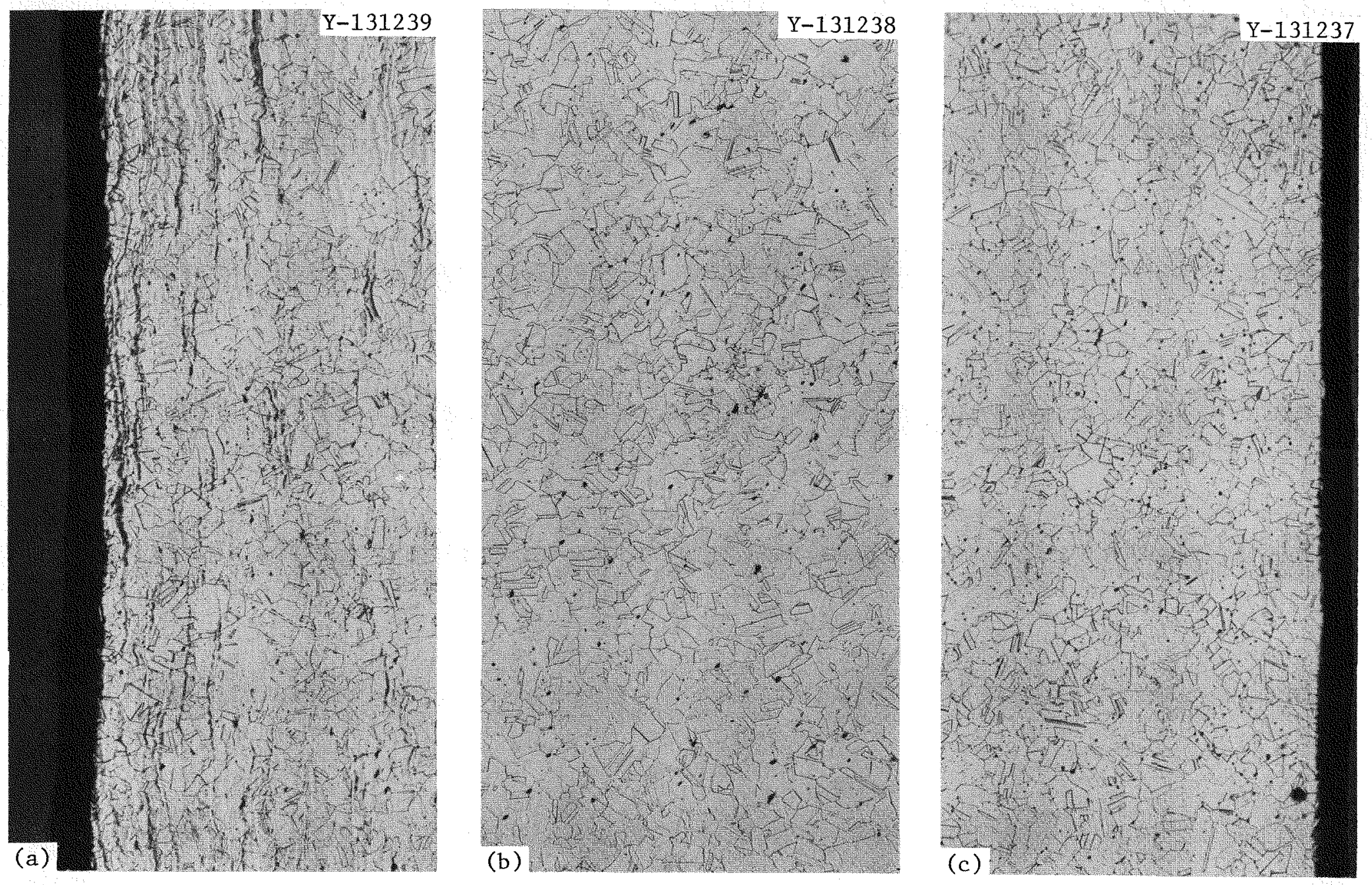

Fig. A4. Microstructure of As-Received 64-mm (2.5-in.) Pipe of the Reference Heat of Type 316 Stainless Stee1. 100×. (a) Inside surface. (b) Midthickness. (c) Outside surface. 

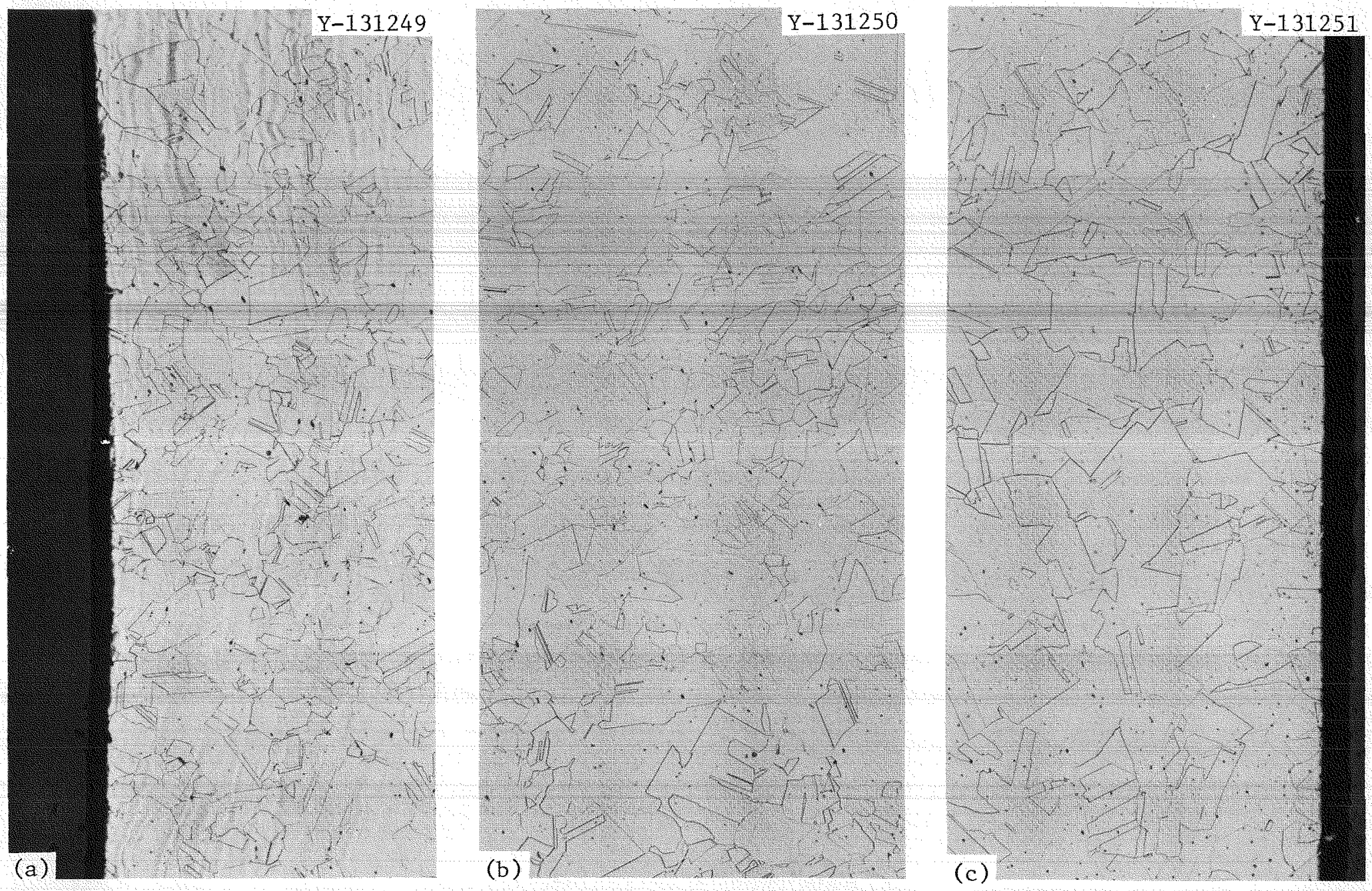

Fig. A5. Microstructure of Reannealed (Hot Furnace, 1 hr at $816^{\circ} \mathrm{C}+0.5 \mathrm{hr}$ at $1065^{\circ} \mathrm{C}$ ) $64-\mathrm{mm}$ (2.5-in.) Pipe of the Reference Heat of Type 316 Stainless Steel. 100x. (a) Inside surface. (b) Transition between midthickness and outside surface. (c) Outside surface. 
Examination of these and other results, in 1ight of ASTM Material Specifications ${ }^{1-3}$ and considerations suggested in the Metals Handbook, ${ }^{4}$ indicates that an annealing treatment of $0.5 \mathrm{hr}$ at $1065^{\circ} \mathrm{C}\left(1950^{\circ} \mathrm{F}\right)$ followed by air cooling should be used for the reference heat of type 316 stainless steel. Since using an initial hot or cold furnace did not produce any difference in resultant room-temperature hardness and grain size, a hot furnace is preferable to cut down on the long heat-up period.

Let us examine the results of the treatment in 1ight of ASTM Specifications and recommendations made in the Metals Handbook.

1. The room-temperature yield strength of the plate reannealed $0.5 \mathrm{hr}$ at $1065^{\circ} \mathrm{C}\left(1950^{\circ} \mathrm{F}\right)$ was $30.6 \mathrm{ksi}(211 \mathrm{MPa})$, compared with a minimum specified value of $30.0 \mathrm{ksi}(207 \mathrm{MPa}$ ).

2. This treatment produced a uniform grain size of approximately ASTM 4 without excessive grain growth. Note in Table 3.6 that the grain size in the transverse direction is smaller (approximately ASTM 5) than in the longitudinal direction, and thus might result in some tendency toward anisotropic properties, such as yield strength. The higher annealing temperature, $1100^{\circ} \mathrm{C}\left(2012^{\circ} \mathrm{F}\right)$, produces a coarse grain structure, approximately ASTM 2.6 .

The yield strength, $S_{y}$, of several heats of type 316 stainless steel can be related to carbon $(C)$ and nitrogen $(N)$ contents and grain size intercept, $d$, by a relationship of the form:

$$
S_{y}=S_{0}+B(C+N) d^{-1 / 2}
$$

where $S_{0}$ and $B$ are constants with room-temperature values of 162 and 4286 , respectively, if $S_{y}$ is in $\mathrm{MPa}, C$ and $N$ in wt\%, and $d$ in $\mu \mathrm{m}$. Equation (1) can be used to estimate the grain size necessary to meet the minimum yield strength of $207 \mathrm{MPa}$ (30.0 ksi). Such a grain size for the reference heat was estimated to be ASTM $4.2(75 \mu \mathrm{m})$ and is consistent with the grain size obtained by the recommended heat treatment. Any higher annealing temperature is likely to yield a coarse grain structure with yield values below the specified minimum. 
The 219-mm (8 5/8-in.) pipe annealed for $0.5 \mathrm{hr}$ at $1065^{\circ} \mathrm{C}$ was subjected to the ASTM A 262-70 sensitization test, which gave negative results, indicating that the air cooling rate was sufficient to prevent any precipitation at the grain boundaries.

We can make the following conclusions concerning heat treatment:

1. The recommended heat treatment for the reference heat of type 316 stainless stee1 $0.5 \mathrm{hr}$ at $1065^{\circ} \mathrm{C}$, followed by air cooling.

2. The temperature of the furnace before reaching the annealing temperature has no influence on the final grain size or room-temperature hardness.

3. The recommended reannealing treatment gives a microstructure that meets the minimum room-temperature yield strength requirement.

4. The transverse grain size is smaller than longitudinal grain size, and this might result in anisotropic properties.

5. The outer skin of the 64-mm (2.5-in.) pipe showed more grain growth than the rest of the materia1, so the outer skin should be avoided in fabricating the specimens.

\section{REFERENCES FOR APPENDIX A}

1. ASTM Designation: A 240-71, "Standard Specification for Stainless and Heat-Resisting Chromium and Chromium-Nickel Steel Plate, Sheet and Strip for Fusion Welded Unfired Pressure Vesse1s," Annual Book of ASTM Standards, Part 3, American Society for Testing and Materials, Philadelphia, April 1972.

2. ASTM Designation: A 312-71, "Standard Specification for Seamless and Welded Austenitic Stainless Stee1 Pipe, Annual Book of ASTM Standards, Part 1, American Society for Testing and Materials, Philadelphia, Apri1 1972.

3. ASTM Designation: A 479-71, "Standard Specification for Stainless Steel and Heat-Resisting Steel Bars and Shapes for Use in Bollers and Other Pressure Vessels," Annual Book of ASTM Standards, Part 3, American Society for Testing and Materials, Philadelphia, April 1972.

4. "Heat Treating of Stainless Steel and Heat-Resisting Alloys," Metals Handbook, vol. 2, American Society for Metals, Metals Park, Ohio, 1971, pp. 243-54. 
APPENDIX B

STRAIN RATE PACER RESULTS 
0 


\section{STRAIN RATE PACER RESULTS}

All tensile data presented in this report were obtained at controlled crosshead speeds. However, ASTM testing procedure ${ }^{1}$ requires that the strain rate of the specimen be controlled with a strain pacer. Since the $0.2 \%$ yield strength of $16-\mathrm{mm}$ (5/8-in.) plate showed ${ }^{2}$ strain rate dependence at room temperature, we tried to use a strain pacer and compare the results with those obtained from a crosshead rate. Figure B1 shows specimen strain rate as a function of strain for a constantcrosshead-rate test. It also includes a plot of crosshead rate for a

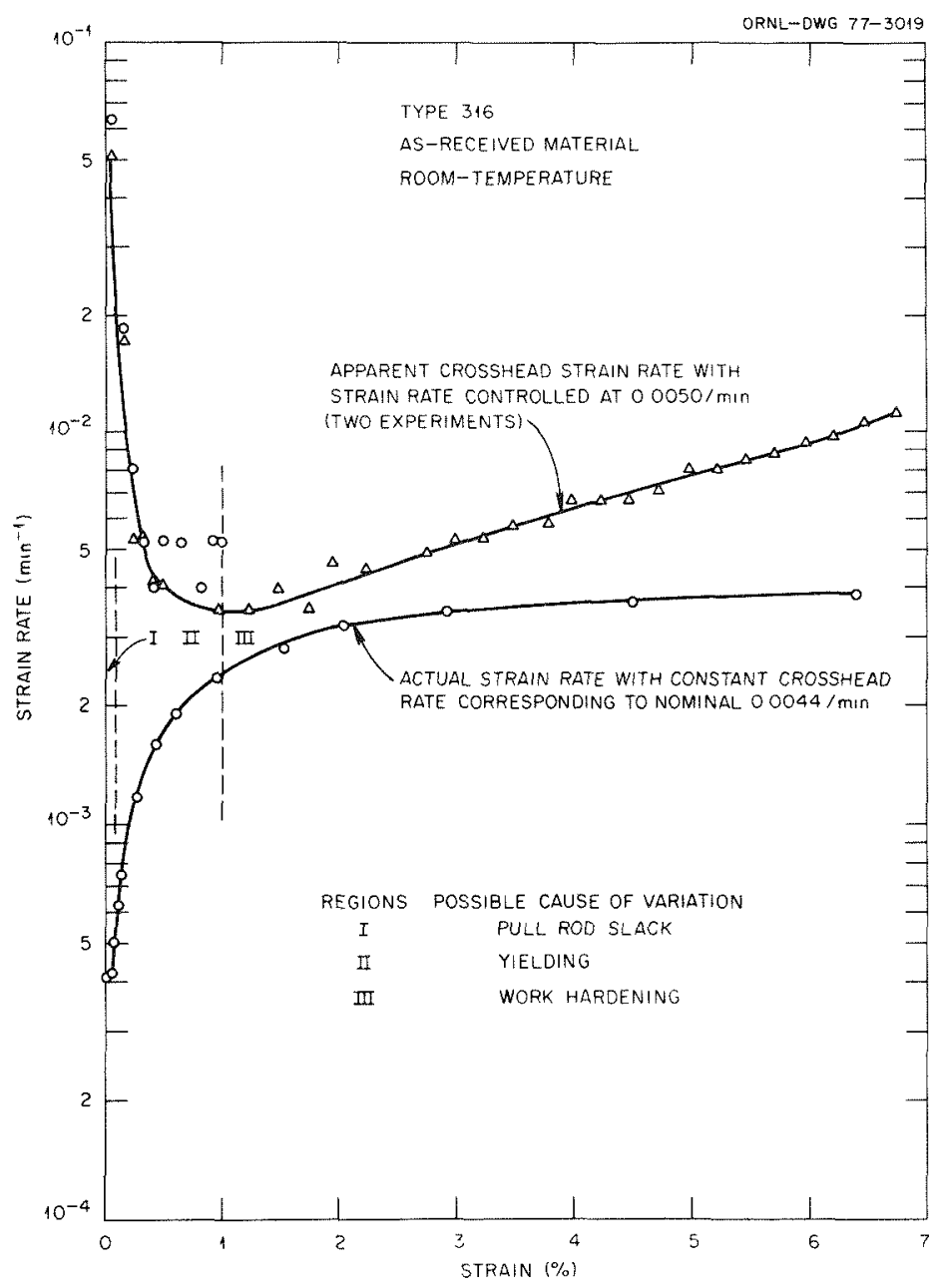

Fig. B1. Relationship Between Strain Rate and Nominal Strain Rate Derived from Crosshead Speed from Experiments with 16-mm (5/8-in.) Plate of Type 316 Stainless Steel. 
constant-strain-rate test controlled with a strain pacer. Both curves can be classified into three different regions:

Region I - This region is controlled by slack in the pull-rod system. For a constant-crosshead-controlled test, slack in the pullrod system causes low strain in the specimen and therefore a low initial strain rate. For a strain-controlled test, slack in the pull-rod system demands a high crosshead rate to maintain a constant strain rate.

Region II - This region is controlled by plastic yielding of the specimen. For a constant-crosshead-control test, strain rate increases because of yielding in the specimen. In other words, a large strain is produced in the specimen for a small increase in the load. For the strain-controlled test, yielding produces a decrease in crosshead rate. This occurs because yielding produces so much strain in the specimen that the crosshead has to slow down to maintain a constant strain rate. Region III - This region is controlled by strain hardening of the specimen. For a constant crosshead rate test, strain hardening lowers the rate of increase in the strain rate. For a constant-strain-rate test, strain hardening of the specimen requires an increase in the crosshead rate to maintain a constant strain rate.

The $0.2 \%$ yield strength values obtained from a constant-crossheadcontrolled test and three constant-strain-rate tests are summarized in Table B1. The two types of tests produce essentially the same values of

Table B1. Effect of Strain Rate Control Method on RoomTemperature $0.2 \%$ Yield Strength Measurements on 16-mm (5/8-in.) Plate of As-Received Reference Heat of Type 316 Stainless Stee1

\begin{tabular}{lcc}
\hline \multirow{2}{*}{ Control Method } & $0.2 \%$ Yield & Strength \\
\cline { 3 - 3 } & $(\mathrm{MPa})$ & $(\mathrm{ksi})$ \\
\hline $\begin{array}{l}\text { Constant crosshead speed to } \\
\text { give nominal 0.0044/min }\end{array}$ & 228 & 33.0 \\
Strain rate 0.0050/in. & 224.7 & 32.59 \\
$\quad$ controlled by pacer & 225.1 & 32.65 \\
$\quad$ (three experiments) & 225.1 & 32.65 \\
\hline
\end{tabular}


yield strength. Therefore, it appears that, at least for austenitic stainless steels, a strain pacer may not be necessary to perform a tensile test. Since the strain pacer produced an insignificant effect on yield strength at room temperature, where strain rate effects were maximum, its influence in elevated-temperature yield strength data is expected to be negligible because of negligible strain rate sensitivity at these temperatures.

\section{REFERENCES FOR APPENDIX B}

1. "Recommended Practice for Tension Tests on Metallic Materials at Elevated Temperatures with Rapid Heating and Conventional or Rapid Strain Rates," Book of ASTM Standards, Part 31, E 151-64, American Society for Testing and Materials, Philadelphia, 1971.

2. V. K. Sikka, R. H. Baldwin, and E. B. Patton, "Tensile Properties of the 16-mm (5/8-in.) Plate," Mechanical Properties Test Data for Stmuctural Materials Quart. Prog. Rep. Jan. 31, 1977, ORNL-5255, pp. $82-90$. 
- 
ORNL-5384

Distribution

Category UC-79b, $-\mathrm{h},-\mathrm{k}$

\section{INTERNAL DISTRIBUTION}

1-2. Central Research Library

3. Document Reference Section

4-10. Laboratory Records Department

11. Laboratory Records, ORNL RC

12. ORNL Patent office

13. M. Bender

14. J. J. B1ass

15. M. K. Booker

16. E. E. Bloom

17. C. R. Brinkman

18. D. A. Canonico

19. J. M. Corum

20. J. H. DeVan

21. J. R. DiStefano

22. C. V. Dodd

23. R. G. Donnelly

24. D. P. Edmonds

25. M. H. Fontana

26. B. E. Foster

27. G. M. Goodwin

28. R. J. Gray

29. W. O. Harms

30. R. L. Heestand

31. R. F. Hibbs

32-34. M. R. Hill

35. J. F. King

36. R. T. King

37. R. L. KIueh

38. K. C. Liu
39. W. R. Martin $(Y-12)$

40. W. J. McAfee

41. R. W. McClung

42. H. E. McCoy, Jr.

43. D. L. McElroy

44. J. W. McEnerney

45. C. J. McHargue

46. A. J. Moorhead

47. P. Patriarca

48. H. Postma

49. C. E. Pugh

50. A. F. Rowcliffe

51. J. L. Scott

52-56. V. K. Sikka

57. W. A. Simpson

58. G. M. Slaughter

59. J. H. Smith

60. S. D. Snyder

61. J. 0. Stiegler

62. J. P. Strizak

63. R. W. Swindeman

64. D. B. Trauger

65. J. R. Weir, Jr.

66. G. D. Whitman

67. G. T. Yahr

68. R. W. Balluffi (consultant)

69. P. M. Brister (consultant)

70. W. R. Hibbard, Jr. (consultant)

71. N. E. Promisel (consu1tant)

EXTERNAL DISTRIBUTION

72-73. DOE DIVISION OF REACTOR DEVELOPMENT AND DEMONSTRATION, Washington, DC 20545

Director

74-75. DOE OAK RIDGE OPERATIONS OFFICE, P.O. BOx E, Oak Ridge, TN 37830

Director, Research and Technical Support Division

Director, Reactor Division 
76-339. DOE TECHNICAL INFORMATION CENTER, Office of Information Services, P.O. Box 62, Oak Ridge, TN 37830

For distribution as shown in TID-4500 Distribution Category, UC-79b (Fuels and Materials Engineering Development);

UC-79h (Structural Materials Design Engineering);

UC-79k (Components). 